\title{
LA MARQUESA DE YOLOMBO” : UNA PROPUESTA DIDÁCTICA DE LA LECTURA LITERARIA PARA JÓVENES DE CICLO IV (GRADO OCTAVO )
}

\section{LUISA FERNANDA NIETO BUSTOS \\ JAIRO ALFONSO VELA NEIVA}

UNIVERSIDAD SANTO TÓMAS

FACULTAD DE ESTUDIOS LITERARIOS

BOGOTÁ

2018 
“LA MARQUESA DE YOLOMBO" : UNA PROPUESTA DIDÁCTICA DE LA LECTURA LITERARIA PARA JÓVENES DE CICLO IV (GRADO OCTAVO )

\author{
LUISA FERNANDA NIETO BUSTOS \\ JAIRO ALFONSO VELA NEIVA
}

ASESOR: RUBÉN DARÍO VALLEJO MOLINA

PARA OPTAR AL TÍTULO DE MAGISTER EN ESTUDIOS LITERARIOS

UNIVERSIDAD SANTO TÓMAS

FACULTAD DE ESTUDIOS LITERARIOS

BOGOTÁ 
La Marquesa de Yolombó: Una propuesta didáctica de la Lectura Literaria. 3

NOTA DE ACEPTACIÓN

Firma del presidente del jurado

Firma del jurado

Firma del presidente del jurado

Bogotá, septiembre 21 de 2018 
La Marquesa de Yolombó: Una propuesta didáctica de la Lectura Literaria. 4

\section{ADVERTENCIA DE LA UNIVERSIDAD}

La Universidad no es responsable por los conceptos expresados en el presente trabajo. 
TABLA DE CONTENIDO

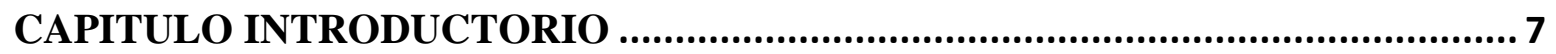

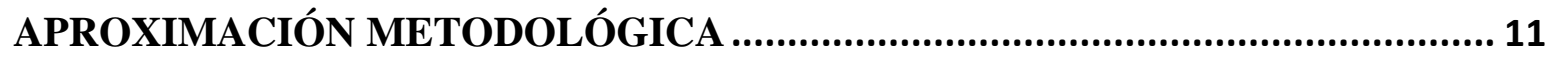

CAPITULO I: ESTUDIOS REALIZADOS SOBRE LA OBRA LA MARQUESA DE

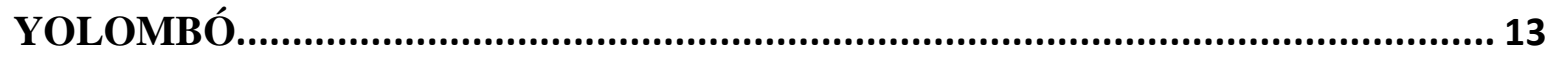

1.1. Aproximación conceptual sobre la novela histórica Latinoamericana.......... 14

1.2. Primer tipo de estudios: La Marquesa de Yolombó en el ámbito histórico... 16

1.3. Segundo tipo: Estudios literarios que analizan la Marquesa de Yolombó desde su función estética y creadora .............................................................................. 25

1.4. Tercer tipo de estudios: La Novela Histórica en el campo de la pedagogía y la

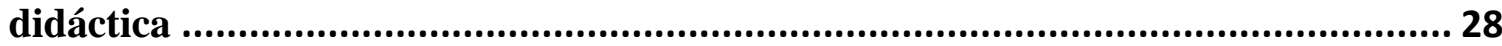

CAPITULO II: LECTURA LITERARIA Y ……................................................ 32

2.1. Lectura literaria ................................................................................................ 32

2.1.1. Proceso formativo de la lectura literaria ..................................................... 34

2.2. La Comprensión Lectora ................................................................................. 40

2.2.1. Estrategias y técnicas de comprensión lectora.............................................. 43

2.2.2. La comprensión lectora en los procesos de enseñanza y aprendizaje.......... 49 CAPÍTULO 3: LA LECTURA LITERARIA DE LA NOVELA HISTÓRICA EN LOS DOCUMENTOS REFENTES DEL MEN............................................................... 51

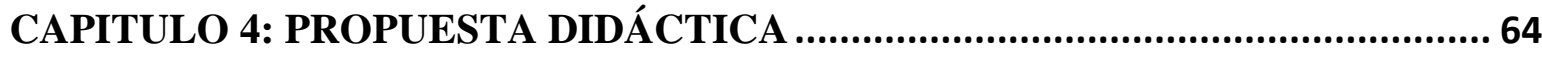

4.1. Marco histórico de la Marquesa de Yolombó........................................................64 64

4.1.1 La reivindicación de lo femenino ...................................................................64

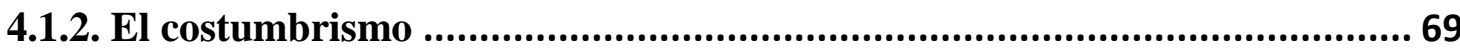

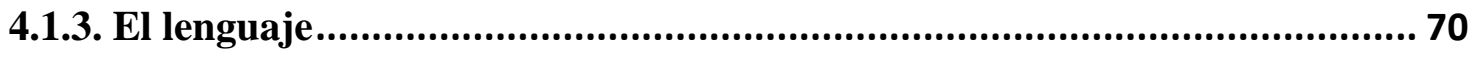

4.1.4. El sincretismo étnico cultural ................................................................... 71

4.2. Didáctica de la lectura literaria de la novela histórica ........................................... 73

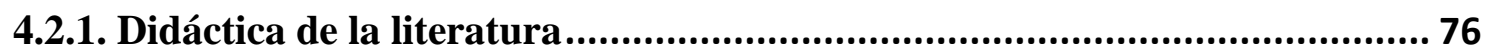


4.2.2. Didáctica de la lectura literaria ...................................................... 79

4.2.1. Didáctica crítica de la lectura literaria ..................................................... 81

4.2.2. Estrategias de lectura literaria en la novela histórica ................................ 83

4.2.2. Secuencia didáctica para los procesos formativos de los docentes ................. 85

4.2.3. La secuencia didáctica de la Marquesa de Yolombó ....................................89

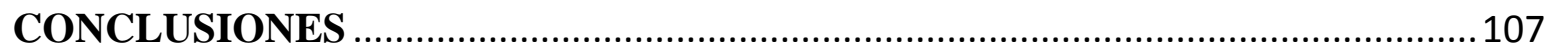




\section{CAPITULO INTRODUCTORIO}

Uno de los temas acuciantes en las clases de literatura tiene que ver con promover los procesos de comprensión lectora en los estudiantes, ya que esto contribuye a una mejor comprensión e interpretación de lo que dice el texto; en ese sentido, en las instituciones educativas Tabora I.E.D ubicado en la Localidad $10^{\circ}$ Engativá y Fabio Lozano Simonelli de la Localidad $5^{\circ}$ Usme, se evidencia una falta de la comprensión lectora y de la lectura literaria de las novelas históricas, por tal razón surge la necesidad de determinar cómo vincular en los planes de estudios de estas instituciones educativas la lectura literaria y la comprensión de las novelas históricas, teniendo como base la obra de la Marquesa de Yolombó del autor antioqueño Tomás Carrasquilla.

En ese orden de ideas, "LA MARQUESA DE YOLOMBO” : UNA PROPUESTA DIDÁCTICA DE LA LECTURA LITERARIA PARA JÓVENES DE CICLO IV (GRADO OCTAVO), y que corresponde al desarrollo de la Maestría en Estudios literarios de la Universidad Santo Tomás, permite a los profesores de la Secretaria de Educación de Bogotá, en su programa de Formación Docente, establecer en el campo pedagógico y didáctico una propuesta que busca reivindicar el papel de las novelas históricas en los planes de lectura de la instituciones educativas, específicamente en la educación media y por supuesto una alternativa didáctica a partir del análisis de obras literarias de carácter histórico como es la novela La Marquesa de Yolombó (1926) de Tomas Carrasquilla (1858 -1940).

Es así como uno de los objetivos prioritarios de un plan de lectura, es ayudar a los alumnos a transformar sus formas de aprendizaje y acercamiento a obras literarias, mediante 
procesos de cambio conceptual y más significativo (Machín, 2016). Sin embargo, en los diseños curriculares, por ser tan susceptibles a la reproducción de lineamientos generales trazados por la política pública, se comete el error de olvidar algunos contenidos, importantes en la construcción de identidad cultural o en el reconocimiento de rasgos históricos característicos de un país; en el presente caso, la obra que se pretende analizar y sobre la cual se creará una propuesta en el marco de la lectura literaria, es de carácter histórico: La marquesa de Yolombó del autor colombiano del siglo XX Tomás Carrasquilla.

En esta obra literaria se observa la tendencia a quedar en el olvido, ya que no se tiene muy en cuenta, a pesar de su importancia, en el marco de su intento por mostrar las costumbres del oriente antioqueño; por el contrario, se desarrollan otros textos y autores como bien lo estipula el Plan Nacional Colombiano de Lectura (PNLE, 2014 a y b) que referencia autores locales como Isaacs, Rivera, García Márquez, o autores internacionales, pero no a Carrasquilla. En ese sentido, surge el problema de investigación: ¿Cómo vincular en los planes de estudio de las instituciones educativas la lectura literaria y la comprensión de novelas históricas colombianas?

En lo que respecta a los objetivos del presente trabajo de grado aparece el objetivo general de la investigación, cuya finalidad es establecer cómo en los planes de estudio de las instituciones vinculan la lectura literaria y la comprensión de novelas históricas colombianas. Para tal efecto, se realizará un estudio de las mallas curriculares y planes de lectura en los grados correspondientes del Ciclo IV en los colegios Tabora I.E.D ubicado en la Localidad $10^{\circ}$ Engativá y Fabio Lozano Simonelli de la Localidad $5^{\circ}$ Usme.

En cuanto a los objetivos específicos se ubica el primero de ellos, el cual tiene por finalidad, fundamentar el concepto de lectura literaria y la comprensión lectora, en los planes 
de estudio en las instituciones educativas. En este apartado se pretende desarrollar cómo se conceptualiza la comprensión lectora y la lectura literaria, con base en los aportes de algunos autores expertos en estos temas.

Mientras, el segundo objetivo corresponde a revisar cómo en los lineamientos curriculares se vincula la lectura literaria en los planes de estudio, mallas curriculares y Derechos Básicos de Aprendizaje DBA. Así, el presente trabajo puede generar estrategias de cumplimiento de los DBA (MEN, 2016), en tanto éste documento plantea que:

Los DBA, en su conjunto, explicitan los aprendizajes estructurantes para un grado y un área particular. Se entienden los aprendizajes como la conjunción de unos conocimientos, habilidades y actitudes que otorgan un contexto cultural e histórico a quién aprende. Son estructurantes en tanto expresan las unidades básicas y fundamentales sobre las cuales se puede edificar el desarrollo futuro del individuo (MEN, 2016, pág. 6)

Se debe, pues analizar las modalidades de lectura, considerar las ideas o estados de opinión previos, la interpretación dominante en el aula, las distintas recepciones de un texto, prever incluso esos "ruidos" que remiten a la distancia cronológica y cultural, y no olvidar que la crítica, esa lectura inteligente, interpuesta, va a orientar y dirigir nuestra interpretación, sin por ello coaccionar nuestra personal lectura, esa interacción lector-texto.

Además de lo anterior, se indagará cuál ha sido o es el modelo de comprensión de lectura que optimice el abordaje de novelas históricas. De esta manera, se revisará cómo se justifican tales modelos y mirar su validez y su ocurrencia desde lo literario, teniendo en cuenta las matrices o planes por colegio (Anexo A), así mismo, los planes de lectura permiten 
organizar la información derivada de los diferentes planes de lectura local, nacional e interamericano (Anexo B).

Finalmente, el tercer objetivo específico busca diseñar una propuesta didáctica que permita el abordaje de la novela histórica la Marquesa de Yolombó. Ya que, el presente trabajo cobra importancia y debe su razón de ser a la manera como un proceso de análisis puede ayudar en la comprensión desde lo histórico y literario a una obra clásica colombiana; mediante el cual se vislumbra realizar una didáctica de la lectura de un texto del género novela en la obra La Marquesa de Yolombó del autor Tomas Carrasquilla. Y, por tanto, al rescatar la obra de Tomás Carrasquilla, se estaría permitiendo no sólo su inclusión en las aulas de clase, sino también otorgar al estudiante un contexto cultural e histórico que permita explicar su cotidianidad y generar nuevos aprendizajes con la riqueza literaria de esta obra.

En esta dinámica, esta investigación es relevante en la medida que brinda elementos pedagógicos y didácticos de la comprensión lectura literaria en el campo de la literatura, con lo cual esto contribuye a la Maestría de Estudios Literarios de la Universidad Santo Tomás; adicionalmente, esta investigación genera un impacto social en cuanto se promueve la lectura literaria de la novela histórica en las instituciones educativas del país, de manera que se logra recuperar la lectura literaria de las obras históricas como aspecto esencial de los procesos de enseñanza con los estudiantes; $y$, finalmente para el investigador este trabajo investigativo es fundamental en la medida que brinda herramientas pedagógicas sobre la educación de la lectura literaria de la novela la Marquesa de Yolombó, e igualmente de otras obras históricas, que contribuyen a mejorar el quehacer pedagógico de la docencia, y por supuesto al mejoramiento de los procesos de comprensión lectora con los estudiantes. 


\section{APROXIMACIÓN METODOLÓGICA}

Este trabajo de grado se propone determinar el vínculo de las novelas históricas y la lectura literaria en los planes lectores de las instituciones educativas, para tal efecto, este estudio se fundamenta en una investigación que es de carácter cualitativo en la medida que pretender comprender y analizar la contribución de la novela histórica la Marquesa de Yolombó en la lectura literaria y la comprensión lectora en los procesos de enseñanza y aprendizaje promovidos en los planes de lectura de las instituciones educativas Tabora I.E.D ubicado en la Localidad $10^{\circ}$ Engativá y Fabio Lozano Simonelli de la Localidad $5^{\circ}$ Usme.

Por lo tanto, se parte de una reflexión y una comprensión analítica del objeto de estudio, a fin de ampliar la visión y el campo de referencia que se tiene con respecto a este, así mismo, se busca desarrollar una estrategia didáctica que permita la inclusión de la lectura literaria y las novelas históricas en los planes lectores de los colegios.

Para tal efecto, se realiza un análisis documental en la presente investigación en los cuatro momentos del trabajo de grado de la siguiente manera: primero, el análisis y la revisión documental con base en las categorías: novela histórica con base en la obra de la Marquesa de Yolombó; el análisis de esta obra literaria, desde su función estética, y finalmente la aplicación de esta obra en el campo pedagógico. Segundo, el rastreo de literatura con base en las categorías: comprensión lectora y lectura literaria, de las cuales se evidencian los referentes teóricos de este trabajo investigativo. Tercero, la revisión documental de cómo en los lineamientos curriculares se vincula la lectura literaria en los planes lectores, mallas curriculares y Derechos Básicos de Aprendizaje DBA. Y, para finalizar el diseño de las secuencias didácticas que permitan el abordaje de la novela histórica la Marquesa de 
La Marquesa de Yolombó: Una propuesta didáctica de la Lectura Literaria. 12

Yolombó, con la finalidad de que las instituciones educativas integren la lectura de este tipo de novelas a su plan lector. 


\section{CAPITULO I: ESTUDIOS REALIZADOS SOBRE LA OBRA LA MARQUESA DE YOLOMBÓ}

Uno de los objetivos específicos de la presente investigación tiene como finalidad, revisar la manera cómo la obra del autor colombiano Tomás Carrasquilla La Marquesa de Yolombó ha sido estudiada en ámbitos didácticos y pedagógicos.

A continuación se registrarán los estudios realizados a partir de la obra, agrupados en tres tipos. El primero, estará enfocado en reconocer la Marquesa de Yolombó como una obra cumbre para la construcción histórica de la región de Antioquia, de la cual se reconoce su función educativa, al relatar la historia de una región colombiana de finales del siglo XIX e inicios del siglo XX, estos estudios demuestran la manera como la literatura - en este caso la Marquesa de Yolombó- está al servicio del hombre en tanto, palimpsesto ${ }^{1}$ de los hechos fundacionales y emancipatorios de los pueblos colombianos.

El segundo tipo de estudios estarán enfocados en trabajos que analizan la obra desde su función estética, creadora; y por último, se revisarán los estudios realizados a la obra la Marquesa de Yolombó en el ámbito pedagógico y didáctico, tópico que desde este punto se puede advertir ha sido escaso; puesto que, pareciera agotarse la obra en el análisis histórico y literario, olvidando su función en el campo escolar como manifestación cultural que requiere ser estudiada en las instituciones educativas colombianas; por consiguiente esta

\footnotetext{
1 Termino que se refiere a la posibilidad que tiene el ser humano para no olvidar. La literatura es entonces testimonio, huella, registro, palimpsesto para afirmar la presencia de la humanidad en el universo. Mijaíl Bajtín hablará de una interacción histórica entre el sujeto de la enunciación y todos los posibles puntos de referencia y destinatarios, a lo largo y ancho de la dimensión temporal y espacial del contexto.
} 
exploración se centrará en indagar las propuestas didácticas existentes para abordar novelas históricas o en la manera como Carrasquilla ha sido abordado en las escuelas regionales o colombianas dado a su importancia histórica y literaria.

\subsection{Aproximación conceptual sobre la novela histórica Latinoamericana}

Determinar con precisión el concepto de novela histórica es, de alguna forma, arriesgado dado que realizar una analogía entre el hecho contado y la delgada línea de la posible interpretación del escritor no es fácil de detectar. Existen posturas que posibilitan una interpretación diferente o similar al conocimiento histórico del lector que inmediatamente se yuxtaponen en el ejercicio de imaginar o de deconstrucción del hecho histórico que se narra.

No hay, entonces, precisión con relación a si este subgénero literario ${ }^{2}$ se da en el contexto latinoamericano de manera que se circunscriban los autores a los hechos y no haya un sesgo en lo contado. Al respecto Javier Rodríguez Sancho en su ensayo "La nueva novela histórica: espacio para el encuentro entre literatura e historia en América Latina y el Caribe en la óptica de Carpentier (2003)", menciona algunas obras latinoamericanas en donde se tocan temas de carácter histórico y en donde, como lectores, sabemos que hay diferencias entre la historia y la novela.

Por ejemplo, la forma como García Márquez en "El general en su laberinto” (1989) y el saber transmitido en la academia tradicional hay muchas diferencias. El desenlace del

\footnotetext{
${ }^{2}$ Se puede llamar subgéneros literarios a cada uno de los tipos de textos que se incluyen dentro de los géneros literarios, caracterizados porque todos tienen rasgos comunes del género al que pertenece (García, 2003, p.3).
} 
libertador a manera de un hombre solitario, vencido por sus achaques, su cruenta vida y el desdén de sus compatriotas es contado de manera natural.

En el mismo escrito se ha traído a colación obras como la Vargas Llosa "La fiesta del Chivo" (2000) que evocan al dictador dominicano Rafael Leónidas Trujillo. Aquí dado el tinte de escritor y político del autor, se da una burla hacia el ser del militar que, durante 30 años, gobernó directa e indirectamente a República Dominicana. Su asesinato, pareció ser como la forma de hacer justicia por parte de un pueblo sentenciado por él a la sumisión en lo que se conoció como Era de Trujillo. Vargas Llosa de manera sarcástica y jocosa valida que este tipo de pueblos y la cultura propician a este tipo de personajes que, a su antojo, dominan los designios de sus gobernados. De manera que la novela histórica adquiere visos de reinterpretaciones de los hechos históricos. Hay que reafirmar que existen diversas clasificaciones de la novela histórica y que haberse basado en el hecho histórico como tal, hace que varíe y se señale tal o cual tipo de género. Ana García Herranz señala en "Sobre la novela y su clasificación"que se tocan temas que son particulares en cuanto que aluden a episodios nacionales y de esto se apean los escritores para narrarlo. Señala que:

Recrear el pasado con sus peculiaridades implica necesariamente que el autor lo haga desde el conocimiento y la perspectiva que se tenga de esa época en el momento en que escribe su novela, lo que se traduce en un anacronismo inevitable, pero necesario, pues es imprescindible una distancia temporal entre el pasado que se quiere novelar y el momento desde el que se novela. (García Herranz, 2011, p. 303).

Ahora bien, la novela histórica es un matiz que representa de una sola forma la historia que unos conocen y la otra que la gente cree conocer. Es decir que entre más distancia haya en el tiempo, para el lector es más difícil corroborar los hechos que le son narrados. Entonces surge 
un interrogante qué de cierto hay entre los hechos y el hecho literario. ¿No debería ser aislado uno del otro? Pareciese ser que hay obligación por parte del escritor de ser fiel a los hechos. Una cosa es el hecho, otro la historia literaria.

Georg Lukács en "La forma clásica de la novela histórica planteaba ya uno de los primeros inconvenientes en mostrar tal cual en los personajes en un momento histórico dado. Al respecto señaló:

Pero tampoco la gran novela social realista del siglo XVII que, al plasmar las costumbres y la psicología de su época, revolucionó la historia universal de la literatura al aproximarse a la realidad, planteó como problema de determinación temporal concreta de los personajes creados. (George Lukács, 1937, p. 7).

Ese punto de partida en cuanto a la verosimilitud y el impacto en el lector podía crear una especie de barrera para el abordaje y aceptación de la obra. Es decir o se acepta de manera ingenua a los personajes y con ellos los hechos históricos o como lector crítico se debe ir a fuentes de carácter meramente a histórico a la posterior comprobación de lo que en verdad sucedió, la menos, de los que se contó.

\subsection{Primer tipo de estudios: La Marquesa de Yolombó en el ámbito histórico}

El primer tipo de estudio supone la compilación que se ha interesado en la novela La Marquesa de Yolombó (1926) del escritor colombiano Tomás Carrasquilla (1858-1908) como una obra cumbre para la construcción histórica de la región antioqueña colombiana.

Al respecto, el escritor Jaime Mejía Duque (1974) escribió el prólogo de la Marquesa de Yolombó en la edición de Kurt L. Levy con la editorial Ayacucho; este crítico literario 
llamará en su prefacio a la obra de Carrasquilla como un "20 de julio literario". Desarrollará su idea través de postulados que le asignan a la novela el valor de ser un reclamo anticolonialista, donde se exige la independencia cultural de la nación; este prefacio no es el primero en darle el valor histórico a la novela del maestro Carrasquilla pero sí encierra en la expresión "20 de julio literario" una visión amplia del autor quién se preocupó por retratar más allá de "cuadros de costumbres" o "anécdotas sarcásticas" las condiciones históricas en que vivió y que forjaron su mundo novelístico y su lenguaje.

La Marquesa de Yolombó (1926) de Carrasquilla da un grito de libertad en la literatura colombiana puesto que, se convierte en una especie de evidencia o palimpsesto ${ }^{4}$ para quienes se interesan en reconstruir los parajes emancipatorios de Colombia, una función histórico literaria en términos de Jaime Mejía Duque.

A continuación aparecen todos aquellos documentos que han trabajado esta postura histórica-literaria de la Marquesa, obra cumbre para la construcción histórica de la región de Antioquia y de Colombia.

Gustavo Forero de la Universidad de Antioquia escribe el artículo" La Marquesa de Yolombó, entre novela etnográfica y novela histórica" donde se propone como tema de reflexión la definición del espacio literario de la novela La Marquesa de Yolombó

\footnotetext{
${ }^{3}$ Esto se evidencia en la Marquesa de Yolombó: Los matrimonios eran fiestas públicas, con matanzas de terneros y de cerdos son contar las carnicerías en montes y corrales; y todo a expensas de padres y padrinos de ambos contrayentes. A la novia la sacaban hecha un altar, la coronaban de cualquier flor y le ponían siempre el velo de castidad. La madrina ritual camarera de honor, estaba a la vela todo el día, para ponerle el coronamiento y hacerle mudar de galas, tantas veces cuantas fuesen las vestimentas que para el caso se tuvieran preparadas. Aquel revestirse arreo constituía el lujo supremo de casaderas y casado (p.123).

${ }^{4}$ Es un manuscrito que conserva huellas de otra escritura anterior en la misma superficie, pero borrada expresamente para dar lugar a la que ahora existe (García, 2007, p.13).
} 
tradicionalmente ubicada entre el campo etnográfico e histórico. Forero parte por definir cada uno de estos géneros de novela.

Novela histórica es entendida como el texto que tiene como propósito fundamental ofrecer una imagen verosímil de una época determinada, preferiblemente lejana para el escritor, en palabras de Forero (2008) los hechos verídicos que toma el escritor son la base para construir sus personajes principales quienes pueden ser inventados o históricos marginales, definición que tomará de la teoría de Georg Lukács a quién retomará en el transcurso de su documento. Por otro lado, se encuentra la novela etnográfica la cual es definida en el artículo como "aquella que describe las costumbres, las creencias de una comunidad, sus mitos, sus genealogías, la historia de su raza, de los pueblos de su región, a partir de los métodos cualitativos de la antropología cultural" (Forero, 2008, p. 88), más luego se pueden encontrar elementos propios de la novela de Carrasquilla con los cuales se puede ubicar La Marquesa de Yolombó entre los límites de la novela etnográfica y novela histórica.

Los argumentos con los cuales clasificará la obra del autor Antioqueño Tomás Carrasquilla como novela etnográfica estarán enfocados principalmente desde la postura de Enrique Anderson Imbert (1954). No parece novela histórica, sino etnográfica. Nos cuenta la vida de la criolla Bárbara desde que, a los dieciséis años, quiere ser minera, hasta que se enriquece, obtiene de Carlos IV el título de Marquesa, es víctima de un pillo que la desposa para robarle los caudales de oro, pierde la razón y la recobra en la ancianidad, cuando América es ya una gusanera de repúblicas. Historia, no; en todo caso, crónica. La postura 
etnográfica también posiciona a la Marquesa de Yolombó dentro de la literatura criollista ${ }^{5}$ colombiana, obra cumbre de este tipo de creaciones. El hecho de ubicar la Novela de Carrasquilla dentro del campo etnográfico permite desarrollar dos aspectos a saber: el primero "demostrar y concretizar las raíces del sincretismo étnico y cultural de Colombia", con todas las influencias detalladas y diferenciadas en su evolución" (Forero, 2008, p. 89) y segundo enunciar los principios ideológicos de Miguel A. Caro que infiltró Carrasquilla en su obra.

Sin embargo, el autor Forero ubica la Marquesa de Yolombó como novela histórica citando nuevamente teóricos estudiosos de los géneros de la novela y sobre todo de la obra de Tomás Carrasquilla; en ese aspecto aparecen los aportes del autor Fernando Onís en la obra de Forero. Fernando Onís asevera que lo que hace Carrasquilla con la Marquesa de Yolombó obedece a una novela histórica la cual reconstruye el pasado de una población antioqueña en el siglo XVIII, a fines de la Colonia y principios de la Independencia "todos pertenecen en efecto al pasado: los criollos, la protagonista, las negras, mestizas o blancas, todos son hermanos de los personajes de las novelas contemporáneas, y hablan y obran como ellos" (Forero, 2008, p. 89) esta cita hace entender la prioridad que la novela histórica le da a los personajes para caracterizar la novela sobre la base criollista- etnográfica.

\footnotetext{
${ }^{5}$ La Marquesa de Yolombó da cuenta del origen pluriétino de Colombia que tendrá sus bases principalmente en el componente español, perspectiva del modelo hispánico que promovió Miguel A. Caro.

${ }^{6}$ Así aparece en la Obra: “ Por la noche hay licor libre, de seis a siete. A los que no van a 1 estanco se lo llevan a donde estén; hay refresco bailable en casa de la anfitriona. Pone la contradanza, aprendida en Antioquia; luego, acompañada de Narcisa, saca las tonadillas y los bundes, los arpegios y panderetas, que se tenían atan guardados. La beldad africana, habituada a estas exhibiciones artísticas, se muestra, si muy en ello, muy en su puesto de negra y de esclava voluntaria. No sabe la hermosa todos los corazones que quiebra" (p. 197)
} 
Para concluir con esta posición historicista Forero cita a Seymour Mentón otro estudioso de Carrasquilla para fortalecer la idea de Mentón de nombrar la Marquesa de Yolombó como la primera novela histórica Latinoamérica porque a partir de una crónica regional Carrasquilla realiza una lectura de la Independencia.

Otro aporte significativo para este primer tipo de estudios que ven en la novela de Carrasquilla la construcción de la historia de Yolombó, es la contribución de la docente de la Universidad de los Andes de Bogotá, Betty Osorio en el marco del proyecto "El papel de la oralidad en la conformación de la identidad nacional" donde produjo el artículo: $L a$ Marquesa de Yolombó. La independencia vivida en el ámbito de la lengua. El propósito de este estudio fue explorar la perspectiva lingüística de la novela, en la cual Carrasquilla usó la lengua como motor que impulsó los procesos de contacto en el campo histórico y social; en el texto Osorio (2003) cita a Poitier quién determina la noción del lenguaje como mecanismo de transmisión de una tradición, a su vez como una efectiva herramienta de subversión.

La lengua es también el lugar en el cual podemos con más efectividad registrar nuestra disidencia con nuestro destino por medio de inversiones, retruécanos, parodias, y permitir así que las energías vernáculas se enfrenten con terminologías reverenciadas. La lengua es la única manera de hacerle el quite a la oscuridad del lenguaje ${ }^{7}$ (Said, citado por Osorio, 2008, p.208)

El autor Osorio a explica la manera como Carrasquilla en su única novela histórica, ilumina el proceso de construcción de una lengua nacional, alejada del proceso evangelizador

\footnotetext{
${ }^{7}$ Por ejemplo: "Lo más particular era que Peralta con tantísimo caudal como iba consiguiendo no se daba nadita di importancia, ni en la ropita, ni en la comida ni en nada: con su misma ruanita pastusa de listas azules, con sus mismitos calzones fundillirrotos" (p.90).
} 
y de la postura homogeneizadora de Rufino José Cuervo que con su Diccionario de Construcción y régimen de la lengua Castellana (1886) quién pretendía normalizar el uso del español; Carrasquilla en oposición a esta postura hace uso de sociolectos nacionales representando elementos culturales, lingüísticos propios del territorio Antioqueño; cuentos como “ A la diestra de Dios Padre" ( 1897), " El ánima sola” ( 1897) y “ Dimitas Arias” ( 1897) indican la permanencia de la narrativa del autor en la cultura oral del mundo rural antioqueño, de símbolos, expresiones lingüísticas y formas discursivas que tienen una impronta colonial hispánica. El propósito de la autora Betty Osorio será explorar en su texto el denso panorama cultural de La Marquesa de Yolombó, como referente histórico de los procesos de emancipación de los esclavos y de la lucha independentista localizadas en el territorio de Antioquía.

Osorio concluye de la siguiente manera a propósito de la función histórica de la novela La Marquesa de Yolombó.

Carrasquilla proyecta hacia un futuro abierto las posibilidades de una sociedad horizontal, la lengua que Carrasquilla les otorga a sus personajes, responde la urgencia de circunstancias históricas, no es un ornamento, ni un ejercicio nostálgico, es una práctica integral que posibilita los debates del siglo $\mathrm{XX}$ pleno de incertidumbres contradicciones y desafíos. El humanismo de Carrasquilla cree en las capacidades de los seres humanos para luchar por sus utopías (...). Su apuesta lingüística saca el español de la biblioteca, la tertulia, la Academia de la Lengua, lo hace vibrar en la voz de Peralta, de Bárbara Caballero y de muchos otros personajes inolvidables, no como arqueología, sino ligada a la vida misma (Osorio, 2008, p. 213) 
En el marco del proyecto de investigación "La Mujer en la Literatura colombiana" Amalia Franco Castaño en el año 2013 realiza un artículo de reflexión en torno a la obra de Tomás Carrasquilla denominado: “ La voz del Personaje femenino ${ }^{8}$ en la construcción de una posición realista crítica desde La Marquesa de Yolombó de Tomás Carrasquilla” texto en el que persigue demostrar cómo la novela histórica de Carrasquilla puede incluirse dentro de las manifestaciones culturales concretas que dan evidencia a partir de sus personajes y las relaciones que existen entre ellos de los ideales de una época concreta en Colombia y por supuesto, la estrecha relación de los personajes femeninos con la postura crítica de Carrasquilla frente al proyecto del llamado Modernismo en Colombia "La actitud antimodernista de la Iglesia, la perpetuación de un sistema de gobierno de corte conservador y la exclusión de ciertos sectores de la sociedad hicieron del proyecto moderno en Colombia una propuesta inacabada e incompleta, resultado de la parcialización y contradicción" (Franco, 2013.p.19), Carrasquilla en su novela histórica aparece para demostrar que la modernidad solo incide en unos sectores de la sociedad colombiana una especie de confrontación con el “artefacto nacional” en palabras de Amalia Franco.

La postura crítica de Carrasquilla lo inscribe más allá del campo costumbrista literario caracterizado por mostrar las tradiciones de la región antioqueña de la que es oriundo, en el campo del realismo crítico dado que, la representación que ofrece del espacio social es una interpretación consciente de la realidad y la historia. Por tanto, lo que hace significativa a La Marquesa de Yolombó no es una curiosidad anticuaria ni una visión monumental del pasado,

\footnotetext{
8 Ocurrírsele a una joven, de aquella época y en aquel medio, tan extrañas y progresistas invenciones, es caso muy personal y peregrino. El solo hecho de aprender a leer y escribir de aquel modo y en las colonias españolas de entonces, implica fuerza de entendimiento y voluntad, facultades especialísimas para iniciar y más aún para arbitrar; que esta ignorancia en que vivían los súbditos del Rey, en estas sus Batuecas de América, no era tanto por el sistema colonial, cuanto por la época, la distancia, la imposibilidad (p. 132).
} 
sino su capacidad para arrojar luces sobre la situación social colombiana de principios del siglo XX y en general sobre el proyecto ilustrado de la modernidad. (Franco, 2013.p.21)

Para Amalia Franco el realismo crítico de Carrasquilla se hace evidente en el personaje de Bárbara Caballero, su voz manifiesta la duda que tiene el autor en la transparencia del lenguaje, La marquesa con un lenguaje directo y fiel a las doctrinas de la iglesia expone las injusticias del entorno, un leguaje contrario a los postulados de la "cultura letrada" que Miguel A. Caro promovía. La voz del Personaje femenino ${ }^{9}$ en la construcción de una posición realista crítica construye desde la referencialidad histórica (alusiones directas de la época colonial, republicana, de los siglos XVIII y XIX) y en otras desde imprecisiones cronológicas y temporales condiciones que permiten entender la función histórica, documental de la obra y a su vez, acercarnos a la evaluación de una época. Dichas evaluaciones se hacen evidentes en la obra en cada una de las transiciones que sufre Bárbara Caballero.

Durante la Colonia (fines del siglo XVIII) Bárbara se mantiene unida a la corona a través de un símbolo, su título de Marquesa; sin embargo, a medida que la imagen del Rey comienza a deslegitimarse, la protagonista revela actitudes y pensamientos distintos para la época, que, aunque no la separan de su compromiso religioso, le permiten modificar relativamente ciertos pre juicios sociales (Franco, 2013.p.21)

\footnotetext{
${ }^{9}$ Yo trabajaría en cualquier cosa, con alma, vida y corazón, como cualquier hombre; pero bien sabe, su Merced, que a las blancas no nos enseñan nada de servir. Nos tienen de ociosas, de bonitas. Ni aun en la casa movemos una paja, porque las negras lo hacen todo. Ahí nos ponen a hilar o a coser cualquier trapo, por matar el tiempo, porque eso ¿qué oficio va a ser para una persona grande, que no sea boba ni loca? Nos crían para ser un tronco de carne, un arnaco inútil. [...] ¡Es una desgracia ser señora! Para más son las negras esclavas, que para algo sirven (Carrasquilla, 1952, p. 129).
} 
Amalia Franco al final de su texto refuerza la idea de no encasillar la obra de Carrasquilla en el folclore pintoresco del costumbrismo, donde la exuberancia de la región sea el único interés del escritor Antioqueño quién por el contrario con la organización de los acontecimientos y la construcción de los personajes (en especial el de Bárbara Caballero) toma una posición evaluativa y crítica de la historia nacional sino además, incorporando problemáticas de corte universal.

En conclusión, la función histórica de la Novela de Tomás Carrasquilla, de acuerdo a lo expresado por los investigadores deja entrever la importancia del lenguaje en la narrativa de la novela, dado que éste recrea y construye la vida de un pueblo colombiano en un determinado contexto histórico. A su vez, la novela reconstruye el devenir de los hombres por medio de parajes cargados de costumbres, descripciones y voces de los personajes que metafóricamente encarnan un sentimiento de libertad apaciguado por la iglesia y el estado pero sin lugar a dudas describe magistralmente las nuevas representaciones culturales que surgieron de las relaciones de dominación, e interacción entre la cultura hispánica, negra e indígena.

Al darle valor a la cultura Africana ${ }^{10}$ por medio de trazar lazos entre Doña Bárbara Caballero y los trabajadores de la mina, por supuesto de raza negra; Carrasquilla permite ubicar en la historia una paradoja que subyace a la dominación esclavista, los dominados no sólo se resistieron a los procesos de aculturación total, sino que se adaptaron a algunas formas

\footnotetext{
${ }^{10}$ Esto se evidencia en La Marquesa de Yolombó: "En el Congo hubiera sido reina, y de reyes descenderá, probablemente. Es una criatura tan negra, de un negro tan fino y tan lustroso, de formas tan perfectas, de facciones tan pulidas, que parece tallada en azabache, por un artista heleno" (p.98).
} 
socioculturales impuestas e hicieron importantes aportes a la sociedad dominante con la variedad y riqueza de sus conocimientos y sus artes.

\subsection{Segundo tipo: Estudios literarios que analizan la Marquesa de Yolombó}

\section{desde su función estética y creadora}

El segundo tipo de estudios relacionados a estudios literarios que analizan la obra desde su función estética, creadora; inscriben el trabajo de Catalina Restrepo de la Universidad de Antioquia llamado “Cantos e interacción cultural en la Marquesa de Yolombó de Tomás Carrasquilla” (2003), un artículo enfocado a presentar la dimensión intercultural de la novela desde una perspectiva estética y antropológica sobre los cantos negros y andaluces y como antecedente colonial del folclore antioqueño incorporado en la narrativa. Este último aspecto será observado en la obra desde la música, el verso y la danza como elementos constantes que vivifican la religiosidad y la mixtura cultural constitutiva de Yolombó.

Algunos personajes como Doña Rosalía Álzate, El sevillano y otros demuestran la tradición en músicas españolas adaptadas a la expresión criolla que más luego se transformarán en pasillos, guabinas, fandanguillos. Será el narrador de la novela quién permita la música por medio de pasajes donde las fiestas, celebraciones públicas y religiosas dejen escuchar las armonías de contradanzas, bundes, torbellinos "expresiones artísticas que componen la gama cultural que se hallaba desde la conquista en tierras americanas y que comienzan a transformarse como resultado del contacto intercultural desde la época colonial” (Restrepo, 2003, p. 28).

Carrasquilla según la autora de esta investigación representa en la Marquesa de Yolombó la interacción de expresiones artísticas diversas que componen la gama cultural que se hallaba en la región y por supuesto Colombia: sincretismo, mixtura, transculturación; 
cierra la autora con una frase de Alejandro Carpentier: “ los instrumentos de Europa, de África y de América, se habían encontrado, mezclado, concertado, en ese poderoso crisol de civilizaciones, encrucijada planetaria, lugar de sincretismos, transculturaciones, simbiosis de músicas aún muy primigenias o ya muy elaboradas, que era el nuevo mundo" (Restrepo, 2003, p. 30).

La Marquesa de Yolombó y el mito en la literatura hispanoamericana de Luis. A. Pérez de la Universidad de Saskatchewan publicado en la revista Hispania, expone la manera como Carrasquilla es uno de los autores que alimentados de la mitología americana se atrevió a explorar y crear un auténtico mito en Yolombó con Bárbara Caballero, con la influencia española romancera y sobre todo los "mitos bárbaros" africanos "El escritor Antioqueño logra armar un escenario excepcional en el que se alterna la Virgen del Pilar con la Madremonte, el Apóstol Santiago con el Patetarro y los Ángeles con los Ilusiones” (Pérez, 1982, p 377).

La investigación aporta a esta revisión del arte en tanto define la novela de Carrasquilla como un mito, un constructo en el que reposan los mismos elementos que la sociedad en la cual se origina, codificando de manera particular y única las creencias populares hasta llegar a construir una especie de mapa de las costumbres y de las instituciones de un grupo étnico.

Luis A Pérez analizará la obra a la luz de la estructura de la narración mítica la cual obedece a una exaltación, infatuación y por último depresión; debate entre la cosmogénesis y apocalipsis. En esencia la Marquesa de Yolombó desarrollará el génesis de una heroína representada en Bárbara Caballero que pese a la época y el hecho de ser mujer se arriesga a conquistar espacios reservados sólo para hombres, cuenta con la aprobación de Santos 
heredados por sus abuelas, amuletos que le servirán para dominar el mundo sobre natural; lugar que a su vez, aprende a conocer a través de sus esclavos. La "Amita de oro" conquistará su título de marquesa con la exaltación a la corona de turno española.

El arquetipo de la seducción del demonio a la mujer, constituirá el apocalipsis en la novela. Bárbara Caballero en el esplendor de su vida cae rendida ante un falso marques que le ofrece matrimonio, hazaña que no ha realizado esta heroína pero, su el único fin de su pretendiente es robar todas sus pertenencias y derrumbar el paraíso que ella construyó. La depresión vendrá después del engaño, la pérdida de todas sus pertenencias tras venderlas por la falsa idea de vivir en España producen en Bárbara Caballero el olvido; pasará treinta y tres años perdida, suspendida en el tiempo, viviendo en el limbo, sin conciencia de sí misma . Para luego despertar en una Colombia ya emancipada de España y organizada en repúblicas.

La realidad en la Marquesa de Yolombó se disuelve en elementos míticos, el mito es mirado como la perspectiva en que el individuo se amalgama con la realidad histórica y social, por esto mismo denominará a la Marquesa como un Quijote de la Mancha Femenino importante categoría en la obra de Carrasquilla:

(...) Me atreví a decir que Don Quijote en España es el caballero andante que sale en defensa de las doncellas y de las viudas, en América Española es una mujer dueña de la tierra, organizadora de empresas, soñadora de imposibles que se hacen reales a su paso, pero que sucumbe al final ante el machismo irrefrenable del hombre, para demostrar que tal vez la superioridad del macho en la especie humana es la más grande mentira y que hay Quijotes femeninos tan famosos en sus aventuras mineras como Don Quijote de la Mancha en su batalla contra los molinos de viento " (Pérez, 1982, p 282). 


\subsection{Tercer tipo de estudios: La Novela Histórica en el campo de la pedagogía}

\section{y la didáctica}

Uno de los objetivos trazados para este trabajo de grado consiste en diseñar una propuesta de didáctica de lectura literaria que permita el abordaje de la novela histórica la Marquesa de Yolombó. Así, el presente apartado pretende indagar sobre la manera como el campo de la pedagogía y didáctica se ha acercado a la novela de Carrasquilla dado a su importancia histórica y literaria en los procesos de enseñanza en la escuela.

La novela La Marquesa de Yolombó Carrasquilla concretamente no ha generado estudios en el campo pedagógico y didáctico, de por sí la novela es una propuesta pedagógica que requiere ser resignificada. En el rastreo realizado lo más cerca al uso educativo de la obra está en el campo teatral y audiovisual; donde al hacer adaptaciones de fragmentos y de la obra completa se pretende dar a conocer la historia costumbrista Colombiana de finales del siglo XVIII.

Si hay algo que ha contribuido a la definición educativa del hombre colombiano, es la televisión; y si hay otra de las alternativas que ha permitido hacer didáctica de la literatura ha sido el teatro. Todos los acercamientos que ha hecho la literatura incluso la literatura histórica han llegado a un público limitado a diferencia de un medio más amplio o masivo como es la televisión por medio de adaptaciones llevadas al formato de telenovelas.

Uno de los fenómenos más importantes de la cultura de masas es sin duda la telenovela. En ella se logra concretar lo que García Canclini ha llamado la hibridación (1990), fenómeno que atraviesa todas las esferas del sincretismo y el mestizaje latinoamericano, que 


\section{La Marquesa de Yolombó: Una propuesta didáctica de la Lectura Literaria. 29}

proviene del estudio de los productores y los públicos culturales que lograron conciliar lo culto y lo popular.

La novela histórica transitó en el cine, la radio y la televisión, adaptándose perfectamente a cada medio gracias a su estructura narrativa fuerte, llena de personajes arquetípicos y conflictos sociales. Gracias a las telenovelas la novela histórica se consolidó como un género popular gracias a su masiva distribución en canales regionales en horarios estratégicos, logrando altos niveles de identificación en el pueblo, una serie de patriotismo novelesco. Entonces, la fuerza de la televisión convirtió la novela histórica televisiva en un hábito regular y familiar, que desarrolló una especie de «contrato mediático con el espectador» (Escudero, 1997) que empezó a mover un público de todas las edades y clases sociales. En ese sentido, a buena parte de colombianos conocieron novelas históricas que jamás hubieran leído por su cuenta pero, que gracias a adaptaciones televisivas reconocieron el valor de estas obras y sobre todo ubican momentos históricos gracias a las adaptaciones literarias.

En un intento de conciliación entre lo culto y lo popular RTI en el año 1978 llevó a la pantalla chica una adaptación de La Marquesa de Yolombó bajo la dirección de Fabio Camero. En el año 2008 con motivo a los 150 años del natalicio de Tomás Carrasquilla la comunidad académica exaltará la vida y obra del autor antioqueño por medio de diferentes actos que homenajeará al hombre y al intelectual que transmitió, a través de sus narraciones, el amor por su tierra y sus gentes. Almudena Mejías Alonso en el marco de esta celebración realiza una aproximación bibliografía sobre Tomás Carrasquilla documento donde enlistará los estudios (monografías, artículos en revistas, bibliografías,...) que puedan aportar datos sobre su vida, su estilo literario y, en definitiva, su importancia en el mundo cultural 
antioqueño y colombiano de los siglos XIX y XX. Trabajo que significa mucho para los estudiosos de Carrasquilla ya que la revisión cuenta con más de cien títulos que desde diferentes campos abordar la vida y obra del autor y sus aportes en el campo cultural, histórico, literario, entre otros.

En el campo pedagógico propiamente a continuación expondremos varias propuestas que emplean la novela histórica como recurso didáctico. El libro: La novela histórica como recurso Didáctico para las ciencias sociales publicado por el Ministerio de educación, política social y deporte de España en el año 2008 abrirá nuestra búsqueda en tanto, a través de los diferentes capítulos hace un recorrido por las distintas etapas históricas por las que la humanidad ha pasado, teniendo como denominador común la novela histórica.

Este libro intentará fortalecer el aprendizaje de la historia con un elemento neutralizador - La novela- la cual servirá como manifestación, ejemplificación, motivación y ubicación para el alumno ante los diferentes ambientes culturales de diferentes épocas históricas. El mutualismo que se intenta dar entre literatura e historia, en este libro estará determinado por una serie de eventos acompañados por novelas que ejemplifican y dan luces de los hechos que el docente requiere ilustrar, más no sugiere una manera como abordar, disfrutar, leer un texto de esta índole, existe una ausencia en la propuesta didáctica, en tanto cosifica la novela a ser elemento motivador y que contextualiza al estudiante. Colombia carece de una propuesta que cuente la historia a través de novelas históricas.

De una manera semejante Elvia Montes de Oca-Navas produce el texto "La novela histórica como apoyo para la enseñanza de la Historia de México” partirá proponiendo una interdisciplinariedad entre las diferentes disciplinas que integran los niveles educativos para 
potenciar la lectura de este tipo de novelas, más luego desarrollará una tesis frente al problema de "veracidad" que se presenta al reunir el relato histórico con el texto narrativo dicotomía que desarrolla de la siguiente manera:

Si bien la literatura tiene que ver más con la ficción que con la realidad, en la novela histórica no debe confundirse ficción con mentira; los contenidos deben ser creíbles, veraces, congruentes, pues el autor tomó como tema de su obra un hecho real, histórico, comprobable. (Navas, 2014, pág. 58). La autora desarrollará a través del documento ciertas categorías con las que pretende definir la novela histórica y genera un campo semántico para correlacionar el término con: autor, historiador, maestro de historia, alumnos, escuela y por supuesto literatura.

Surgen ciertos cuestionamientos frente a la relación que se promueve entre la novela histórica y los lectores escolares: En el momento de promover la novela como herramienta motivacional, ilustrativa de la clase de historia ¿Qué sucede con los elementos internos narrativos de la obra?, ¿A caso estos elementos no tienen una connotación histórica y pueden potenciar el estudio de este mismo?, ¿A caso la novela histórica carece de elementos propios que sea quien impulse, potencie desde sus propios eventos el hecho histórico?, Por otra parte el estudiante lector ¿Cómo aborda la novela histórica desde la ficción o como hecho real?, ¿De qué manera establece esa división necesaria?, ¿ Qué pasa con el deleite y disfrute de la novela? Y por último el docente ¿Cómo guía al lector escolar en la lectura de este tipo de textos?, ¿Cuáles son las competencias que debe fortalecer dentro de este tipo de lectura asociada con la lectura de la realidad?, ¿Es válido usar la novela como artefacto motivacional, ilustrativo? ¿El lugar que merece la novela histórica es de recurso didáctico complementario? 


\section{CAPITULO II: LECTURA LITERARIA Y COMPRENSIÓN LECTORA}

Este capítulo tiene por finalidad, comprender el concepto de lectura literaria y la comprensión lectora, en los planes de lectura en las instituciones educativas; para tal efecto, este apartado se desarrolla con base en las categorías: comprensión lectora y lectura literaria, de la siguiente manera.

\subsection{Lectura literaria}

La importancia de la lectura en los estudiantes es fundamental para generar nuevos aprendizajes y conocimientos en el aula, no obstante, aprender a leer no es sólo decodificar e interpretar un texto, sino darle sentido como herramienta cultural que interviene en el desarrollo individual y como elemento de transmisión cultural en la vida de los sujetos. En esta línea la investigadora Isabel Solé (1992) define la lectura como "un proceso de interacción entre un lector y un texto, proceso mediante el cual el primero intenta satisfacer obtener una información pertinente” (p. 29). Por su parte, Rockweel (2005) asevera que la lectura, reconocida como práctica social y cultural, se define como "una actividad productiva, no exenta de variabilidad, en los límites de las regulaciones de significados dadas por sus condiciones materiales y simbólicas" (Rockwell, 2005, 26). En suma, la lectura es relevante en el desarrollo individual del lector, a su vez, es una práctica socio - cultural, y contribuye a la consolidación de significados en las distintas interacciones que se da entre el lector y el texto.

A este respecto, aparece la relevancia del lector en la lectura, en cuanto se habla de un lector activo que procesa y examina el texto y, en segundo lugar, el lector que siempre se lee 
para alcanzar alguna finalidad (evadirse, obtener información, seguir instrucciones, etc.). Por lo tanto, los lectores interpretan los textos que leen en función del objetivo que preside su lectura; así mismo, “el lector debe conocer, aunque sea intuitivamente, las características de las diversas estructuras textuales" (Solé, 1987, p.21). Para lograr este propósito, hablar, leer y escribir son actos culturales que no se aprenden solos, puesto que la aproximación del niño a la literatura se hace a través de la lectura, pero "ella supone un complejo recorrido en el que el acompañamiento es esencial” (Merino, 2011, p. 41).

Esto conlleva a desarrollar la importancia de la lectura literaria en los procesos de enseñanza, a lo cual es indispensable destacar que "si el lector no ha tenido contacto con la literatura desde la infancia o en los años de su formación, no estará acostumbrado a leer textos literarios" (Ferrada et al., 2009). En ese sentido, se requiere implementar la lectura literaria desde una posición social e histórica del texto, para tal efecto, se necesita "clasificar "bien" los textos en géneros o determinar correctamente una secuencia narrativa, entre otros, son los saberes enseñados que permiten dominar los riesgos que supone el hecho de que no haya una univocidad en el sentido ni conservación de lo estético" (Ferrada, Et al., 2009, p.12).

Si los textos literarios, los alumnos y los docentes protagonizan las prácticas de lectura enmarcadas en la enseñanza de la literatura, por ende, se trata de poner a la lectura en plural, no en una multiplicidad en apariencia infinita; al respecto, es necesario un posicionamiento sobre "la literatura que dé cabida a las lecturas que traen diferentes posiciones sociales e históricas, así como otros regímenes de saberes” (Cuesta, 2013, p. 104). Esto trae como consecuencia, que se organice y se establece una lectura literaria contextualizada y socio- histórica que responda a las necesidades de los estudiantes, y por consiguiente replantee el proceso formativo de los textos literarios. 
En resumen, la lectura literaria es esencial para el desarrollo de la subjetividad, el pensamiento simbólico, la imaginación y la creatividad; de ahí que "es en el mundo posible de la ficción donde el hombre se encuentra realmente libre para pensar, para configurar alternativas. En la literatura el ser humano, libre del hacer práctico y de la necesidad, viaja por otros mundos posibles" (Queiroz, 2009, p.32). Así, la lectura enriquece y amplia el conocimiento en el estudiante, y por esta razón, es indispensable la apuesta por procesos formativos en la lectura literaria que desarrollen la imaginación, la creatividad y la crítica, en la lectura de obras literarias.

\subsubsection{Proceso formativo de la lectura literaria}

Para el autor Lomas (2002), la formación de la lectura literaria pasa por la capacidad del docente de orientar la educación literaria a "la adquisición de hábitos lectores y a la formación de lectores competentes. Se dio por terminada la hegemonía literaria en la enseñanza del lenguaje" (p.78). De esta manera, el énfasis se centra en una formación lingüística con base en la reflexión sobre la producción oral y escrita. Así surge "la concepción del texto literario como desviación de la norma y la función de la literatura como uno de los usos sociales de la lengua" (Colomer, 2005, p.44). Esto conlleva el desarrollo de la competencia literaria a través de la lectura y de la formación de instrumentos interpretativos, basados en el análisis de los elementos que configuran las obras literarias.

En ese contexto, la lectura literaria tiene como función primordial: la del placer de leer, para desde allí desarrollar, "la idea de la función formativa de la imaginación, y luego las posibilidades de potenciación de pensamiento crítico" (Lomas, 2002, p.81). Es decir, que la lectura literaria en el proceso formativo de los estudiantes responde al uso de la imaginación en ese proceso cognoscitivo que se da entre el proceso de lectura del texto literario, y la interpretación del lector, para que luego el estudiante desarrolle su postura 
crítica frente a lo que comprendió del texto, interpretó del mismo y posteriormente dio su pensamiento crítico sobre la obra literaria.

Así pues, generar un proceso formativo de la lectura literaria implica pensarla como "una actividad que tiene que ver con la subjetividad del lector: no sólo con lo que el lector sabe, sino con lo que es. Se trata de pensar la lectura como algo que nos forma (o nos deforma o nos transforma)" (Larrosa, 2007, p. 25). Entonces, la formación de la lectura literaria en el estudiante pretende que éste logre transformarse en su subjetividad, a partir del criterio crítico del lector al terminar de leer una obra literaria.

Por eso, en la tarea de enseñar a leer literatura, cumple un importante rol el profesor, como incentivador y facilitador de la lectura. Pensar la lectura literaria como formación "sería intentar pensar esa misteriosa actividad que es la lectura como algo que tiene que ver con aquello que nos hace ser como somos" (Larrosa, citado por Hauy, 2014, p. 26). Así mismo, para que la lectura se resuelva en formación “es necesario que haya una relación íntima entre el texto y la subjetividad. Y esa relación podría pensarse como experiencia, que sería lo que nos pasa. No lo que pasa, sino lo que nos pasa” (Larrosa, 2007, p. 28).

La experiencia que se logra a partir de la lectura literaria se construye en la capacidad del sujeto de generar un pensamiento narrativo, el cual se concibe como un "instrumento de la libertad, la luminosidad, la imaginación y, sí, la razón” (Bruner, citado por Calvo y Cabernero, 2014, p. 110). A través de la narración se construye la identidad, puesto que el “yo es un producto de nuestra narración (de nuestro modo de hablar y de escribir)" (p. 85). Según este presupuesto, la narrativa le permite al individuo construir sentido, y contar historias es crucial para la interacción con los demás interlocutores, de ahí que la experiencia que surge en el pensamiento narrativo contribuye a que el sujeto construya nuevos significados e intersubjetividades, desde su experiencia con la lectura de las obras literarias. 
De este modo, se aborda la lectura literaria como un arma de integración social a través de un espacio que provoca una intersubjetividad entre diversos lectores, y así se configurar nuevos horizontes de sentido de comprensión de los textos literarios y por supuesto, se refuerzan las identidades. Además de ello, la lectura supone "una interacción recíproca (transacción) entre texto y lector, pues el lector elabora significados vinculando al discurso literario sus emociones y experiencias" (p.91).

Es decir, que el proceso formativo de la lectura literaria responde a la necesidad de que el docente genere la construcción de sentidos e identidades en la experiencia narrativa que tienen los estudiantes al acercarse a las obras literarias; a su vez, esto presupone una formación literaria en la cual se desarrolle una dialéctica entre el texto y el texto, para poder visibilizar la emociones que suscitan los discursos literarios en el estudiante. Desde esta visión, se evidencia que al primer encuentro con el texto, a las expectativas del lector y a la aportación de la experiencia previa del lector posibilitará el diálogo, y el pensamiento crítico, con el texto, aspectos fundamentales en los procesos de enseñanza y aprendizaje en el aula.

De ahí la necesidad de entregar formación a los profesores para prepararse como mediadores de la lectura literaria, ya que se requiere de personas comprometidas con la importancia de iniciar tempranamente a los niños en el discurso literario. En Colombia, "la mayor parte de los niños que participan de la educación preescolar pertenecen a sectores social y emocionalmente vulnerables en los que la familia está lejos de constituirse en fiel aliado para el proceso de construcción del lector y, menos aún, literario" (Cuesta, 2013, p. 115).

Por esta razón, se necesita de la generación de talleres literarios en el aula como recurso lúdico que busca conectar con la experiencia lectora de los estudiantes y fomentar la escritura creativa. Al mismo tiempo, "la estimulación del pensamiento crítico que se logra a 
través de la producción de textos con intención literaria constituye también una forma de educación" (p.116). Para este cometido, es indispensable que en los procesos de enseñanza y aprendizaje se desplace "la concepción del lenguaje desde el paradigma funcional, fracturado e interesado exclusivamente por el desarrollo de competencias funcionales desligadas de todo contexto real y simbólico, a uno socialmente solidario" (Ferrada, Et al, citado por Cuesta, 2013, p. 118).

Se trata de ofrecer una noción de experiencia para la comprensión de la enseñanza de la lectura literaria, por ejemplo, la investigadora Martina Fittipaldi, quien analizó las lecturas literarias ofrecidas por alumnos de distintas instituciones educativas de la Provincia de Salta (Argentina). En dicho trabajo,

Varios niños y jóvenes daban cuenta de distintas orientaciones de significados enmarcadas en apelaciones a otras discursividades. Así, Fittipaldi señala: [...] cuando los chicos leen lo literario desde sus propias "claves": la televisión, los videojuegos o la Internet muchas veces son las plataformas desde las que los niños construyen sus saberes acerca del mundo (además de la familia y la escuela) y desde las que leen y con las que relacionan las obras literarias (Cuesta, 2013, p. 118).

Por tanto, el proceso de enseñanza y aprendizaje de la lectura literaria se encuentra en marcado en la capacidad del docente para generar estrategias de aprendizaje, a partir de las cuales el estudiante pueda desarrollar a través de su experiencia de vida, producir otros discursos y narrativas que se dan en la lectura literaria, y que por ende están íntimamente relacionadas con las experiencias fundantes del lector, se trata de una construcción de saberes que conecta el mundo, las vivencias del lector, con lo que acontece en la lectura de la obra literaria, esto permite que se desarrolle en el proceso de enseñanza una educación literaria 
que responda al desarrollo de hábitos de lectura, y de competencias interpretativas del lector como se explica a continuación:

Tabla 1: Educación de la lectura literaria

\begin{tabular}{|c|c|c|}
\hline & $\begin{array}{l}\text { COMPETENCIA } \\
\text { INTERPRETATIVA }\end{array}$ & HÁBITO DEL LECTOR \\
\hline CORPUS & $\begin{array}{l}\text { - Textos con problemas de } \\
\text { comprensión } \\
\text { - Postura de interrogación al } \\
\text { texto literario }\end{array}$ & $\begin{array}{l}\text { Diversidad: ofrecer un menú variado } \\
\text { de lecturas literarias. }\end{array}$ \\
\hline DISPOSICIÓN DE LECTURA & $\begin{array}{l}\text { Espacios de lectura } \\
\text { obligatoria que permiten el } \\
\text { estudio colectivo de los } \\
\text { textos. }\end{array}$ & $\begin{array}{l}\text { Habilitar tiempos de lectura individual } \\
\text { y silenciosa. }\end{array}$ \\
\hline POSTURA DE LECTURA & $\begin{array}{l}\text { - Protocolo de lectura: } \\
\text { derechos del texto } \\
\text { (Horizonte interpretativo } \\
\text { construido por la obra } \\
\text { literaria), y los derechos del } \\
\text { lector (en la construcción de } \\
\text { significados). }\end{array}$ & $\begin{array}{l}\text { Recuperar la postura lectora, a partir } \\
\text { de la apropiación del texto. }\end{array}$ \\
\hline ACTIVIDAD MEDIADORA & $\begin{array}{l}\text { El docente planifica espacios que } \\
\text { permitan la emergencia, circulación y } \\
\text { confrontación de las interpretaciones } \\
\text { de los alumnos. }\end{array}$ & $\begin{array}{l}\text { El docente es quien debe garantizar y } \\
\text { facilitar el acceso a la amplia } \\
\text { diversidad de textos que este objetivo } \\
\text { educativo requiere. En ese marco, } \\
\text { algunas de sus principales funciones } \\
\text { serían: potenciar un ambiente cultural } \\
\text { en el cual se lee, se comparten las } \\
\text { lecturas y se favorece la participación } \\
\text { en verdaderos circuitos social }\end{array}$ \\
\hline
\end{tabular}

Fuente: Munita, febrero de 2017. 
Según lo anterior, Colomer (2001) enfatiza en que la educación literaria se orienta hacia dos grandes aspectos: el primer aspecto, favorece el avance en la competencia interpretativa; y, por ende, "promueve la construcción de hábitos lectores así como una relación placentera y de implicación personal frente a los textos" (Colomer, citado por Munita, 2014, p. 378). Esto implica la superación tanto de una enseñanza literaria basada únicamente en el saber, a otra basada en la concreción de un proceso formativo que pretende lograr que los alumnos participen con efectividad en los procesos de recepción del discurso literario, con base en una relación de placer con la obra literaria.

$\mathrm{Y}$, el segundo aspecto, consiste en que la idea de que enseñar literatura es, "en principio, enseñar una manera de leer" (Munita, 2014, p. 380). Es decir, "no es el dominio de un patrimonio de obras, ni la apropiación de los valores morales que estas vehiculan, ni el análisis de las características formales de su literariedad" (p.381). Sino que corresponde a un saber leer literario que, al finalizar su escolaridad, los estudiantes puedan poner en juego en sus lecturas libres y personales. Pues, si de lo que se trata es de formar lectores literarios que se sientan implicados en la lectura, y que además puedan poner en juego formas variadas de comprensión y fruición sobre los textos, "trabajar en la adquisición y el progresivo dominio de esta forma de lectura parece ser el mejor aporte que pueda hacer la escuela en la formación lectora de las nuevas generaciones" (p.382).

Para desarrollar un aprendizaje adecuado en la enseñanza de la lectura literaria, se requiere de un implicación personal del estudiante con la literatura, dado que esto favorece "el desarrollo de habilidades de interpretación inferencial de las obras, o la diversificación de las formas de fruición propias del lector literario" (p. 379). Al respecto, el autor Lomas (2006) explica la necesidad de incentivar en el aula la experiencia de la comunicación literaria ya que "los estudiantes avanzaran en su competencia literaria en la medida que 
entiendan al leer los textos literarios que son una expresión de la vida cotidiana de las personas" (Lomas, 2006, p.20). Para ello, se recomienda utilizar textos de lectura literaria cuya textura formal o semántica facilite la comprensión de su significado pero a la vez inviten a la lectura en los estudiantes.

Adicionalmente, se debe suscitar la implicación de los estudiantes en la lectura literaria en la medida que estos textos les traiga consigo algún tipo de placer estético y algún tipo de emoción que desarrolle en ellos la creatividad. Para este propósito, se necesita de una " secuencia de aprendizaje en torno a textos literarios, de los cuales se tenga en cuenta el grado de dificultad de convenciones textuales utilizadas en cada texto con el fin de hace posible la identificación de los mecanismos de construcción de sentido en la ficción literaria y en consecuencia el acceso de los estudiantes al significado de la obra literaria) (p. 21).

Y, en el campo de la didáctica de la enseñanza de la lectura literaria surge la necesidad de generar estrategias de aprendizaje que contribuyan a la comprensión de los textos literarios. Por ejemplo, la utilización de estrategias didácticas como son: la identificación de la idea principal, de la estructura textual, del tipo de texto y efectos comunicativos, de inferencias y recursos textuales, semánticos y retóricos que evidencian los las obras literarias, y que coadyuvan a una comprensión de estas obras literarias y su respectiva interpretación textual.

\subsection{La Comprensión Lectora}

La comprensión lectora es un aspecto fundamental en los procesos de aprendizaje de los estudiantes, puesto que comprender lo que dice el autor en su obra es requisito para que se logre entender y luego generar una perspectiva crítica sobre lo leído. En ese aspecto, la lectura 
se concibe como una fase de creación que aporta, enriquece y recrea el texto, es un proceso que le permite "al lector construir significados de forma activa, aplicar estrategias efectivas de lectura y reflexionar sobre su propio proceso lector" (Guthrie, citado por Hoyos y Gallego, 2017, p.1). A su vez, leer es, por lo tanto, "una interacción entre el texto, el contexto y el lector en una extracción y construcción de significados" (p. 2).

En relación con lo anterior, y teniendo en cuenta las habilidades del pensamiento y la psicología de la lectura, se puede señalar que la lectura "es un proceso complejo que comienza con la función visual: inicialmente, hay un reconocimiento visual de los símbolos y la asociación de los mismos con las palabras" (p.5), para pasar a la relación de éstas con las ideas. En esta configuración se pone en funcionamiento una serie de procesos cognitivoslingüísticos que permiten obtener una adecuada información del lenguaje escrito.

La lectura como una compleja actividad mental supone de un supuesto estructural en el cumplimiento de su objetivo principal: la comprensión. Es así como se comprende algo en la medida que se le atribuye un significado propio, personal, "que se constituye por la interacción que tiene lugar en una situación o tarea específica de lectura entre dicha afirmación presente en el texto y las aportaciones del lector" (Lomas, 2014, p.86). Es decir, que comprender implica fundamentalmente inferir el significado a partir del texto a través de los contenidos y el conocimiento que se aborda.

Por consiguiente, la pertinencia de la comprensión lectora busca comprometerse con la lectura, pues se trata de "comprender textos diversos a nivel profundo, poder utilizarlos, poder reflexionar sobre su contenido para pensar y ampliar el conocimiento, para potenciar el desarrollo cognitivo, social y afectivo de los sujetos" (Mayoral, 1987, p.93). Para lograr este propósito, existen algunos factores que contribuyen a la comprensión del texto como es 
el caso del tamaño de la letra, el tipo y clase de texto, la complejidad del vocabulario; a su vez se destacan factores internos al propio sujeto lector, tales como ciertas "habilidades de descodificación, los conocimientos previos que el lector tiene sobre el tema y las habilidades de regulación de la comprensión" (Sanz, 2012, p.129).

Entendida así la lectura y el acto de leer, puede definirse la comprensión lectora como:

Un proceso complejo que supone la interpretación de un conjunto de palabras con relación a un contexto significativo ${ }^{11}$, así como la percepción del impacto de su fuerza sensorial, emocional e intelectual. Se hace necesario vincular la palabra a la experiencia del lector, dado que tal proceso está precedido de la compenetración del lector con un texto dentro de un contexto determinado (Gispert, 2001, p.39).

Es decir, que en el proceso de la competencia lectora lo que dice el texto a partir de su contexto, y luego su respectiva interpretación conlleva a que se dé una interacción entre el lector y el autor de ese texto. Al respecto, el autor Ausubel menciona que la comprensión de lo que se lee es producto de dos condiciones: primero, “de la claridad y coherencia del contenido de los textos, de que su estructura resulte familiar o conocida, y de que su léxico, sintaxis y cohesión interna posean un nivel aceptable” (Ausubel, citado por Sole, 1998, p.13). Y, segundo, del grado en que el conocimiento previo del lector sea pertinente para el contenido del texto. En otras palabras, "de la posibilidad de que el lector posea los conocimientos necesarios que le van a permitir la atribución de significado a los contenidos del texto" (p.15). Es decir, para que el lector pueda comprender, es necesario que el texto en

\footnotetext{
${ }^{11}$ Por ejemplo, en la Marquesa de Yolombó: "Lo más particular era que Peralta con tantísimo caudal como iba consiguiendo no se daba nadita di importancia, ni en la ropita, ni en la comida ni en nada: con su misma ruanita pastusa de listas azules, con sus mismitos calzones fundillirrotos" (p.90).
} 
sí se deje comprender y que el lector posea conocimientos adecuados para elaborar una interpretación acerca de él.

En esa dinámica, existen dos requisitos básicos para el desarrollo de la comprensión lectora: primero, adquirir y dominar las habilidades de reconocimiento y decodificación de las palabras, y, segundo, “adquirir habilidades de búsqueda y construcción de significados, utilizándolas estratégicamente bajo control cognitivo" (p.17). A partir de estos dos presupuestos, se necesitan de algunas estrategias y técnicas de comprensión lectora que faciliten el desarrollo de habilidades cognitivas y lingüísticas en la comprensión de los textos como se explica a continuación.

\subsubsection{Estrategias y técnicas de comprensión lectora}

La constante interacción que se da entre el contenido del texto y el lector, está regulado por la intencionalidad por la cual se lee el texto, a partir de un conjunto de micro procesos que ayuda a la comprensión significativa de aquello que se lee. En ese sentido, las estrategias de comprensión lectora actúan "como procedimientos reguladores de la propia lectura" (Bofarull, Et al., 2001, p. 97). Así, estas estrategias se consideran como objeto de enseñanza y aprendizaje en el aula de clases. De esta manera, el uso de una determinada estrategia lectora en el proceso de enseñanza de parte del docente presupone tener presente: "los contenidos conceptuales; la significación y el sentido de las tareas; la claridad de los objetivos de aprendizaje; las condiciones y la finalidad de las tareas" (p.98).

A partir del uso autónomo y eficaz de las estrategias lectoras conlleva a que los estudiantes puedan: primero, extraer el significado del texto; segundo, "saber reconducir la lectura, avanzando o retrocediendo en el texto; y, tercero, conectar los nuevos conceptos con los conocimientos previos que le permitirán incorporarlos a su conocimiento" (Cooper, 1990, 
p.134). Por ende, si se favorece el conocimiento y el aprendizaje de los micros procesos en la comprensión lectora, se consolidan los mecanismos de autorregulación de la lectura por parte del lector, como lo explica el autor Joan Serra (1997) a continuación:

Tabla 2: Comprensión lectura y aprendizaje

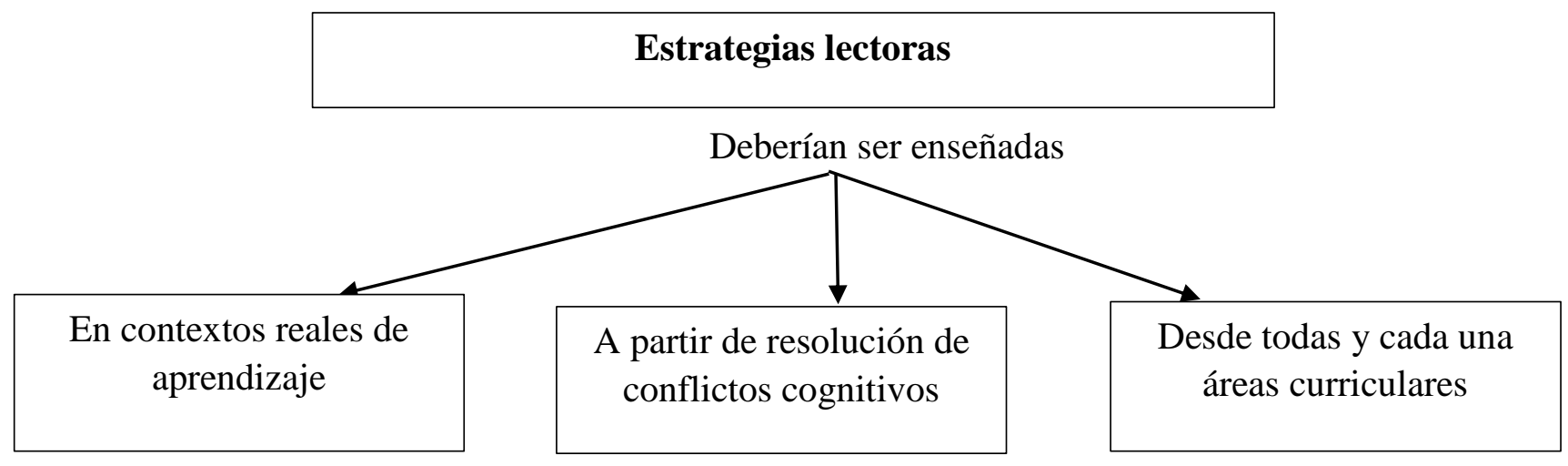

\section{Comprensión lectora}

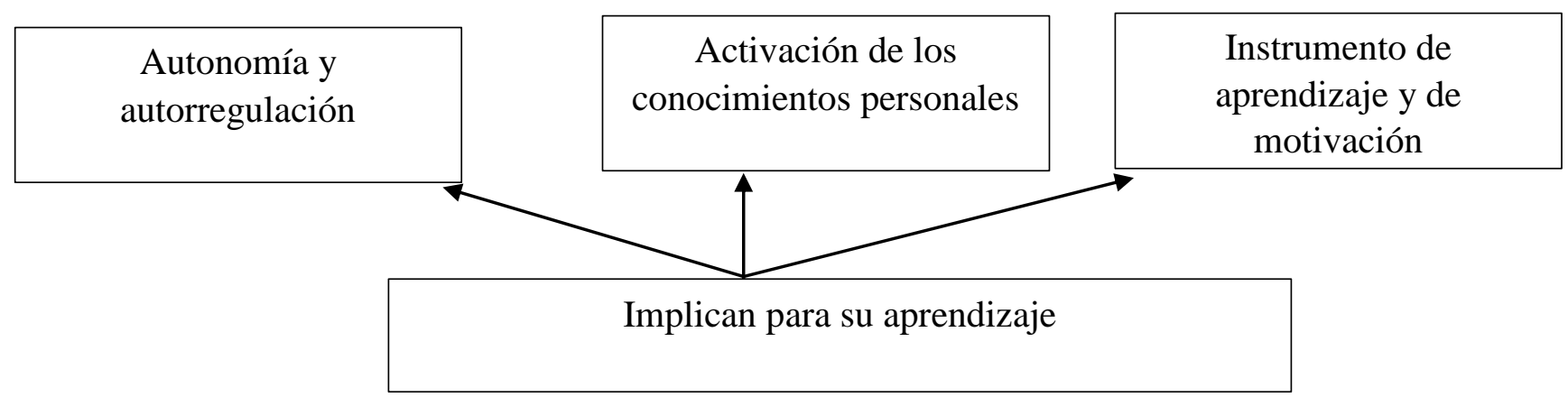

Fuente: Joan Serra, 1997

Para llevar a cabo un adecuado proceso de comprensión lectora en los procesos de enseñanza y aprendizaje se requiere de ciertos aspectos que contribuyen al éxito en la comprensión de cualquier tipo de texto. Acto seguido, se explican las dos grandes estrategias de comprensión lectora: 
Primero, aparece la descodificación con fluidez; cuya finalidad busca en la capacidad de lector de interpretar los símbolos de cada lengua, para este propósito se requiere releer el texto para comprender su significado; luego, se da paso a evaluar "la consistencia interna del contenido que expresa el texto y su correspondencia con los conocimientos previos y lo que dicta el sentido común" (Sánchez, 1995, p.48), se trata entonces de tener una actitud crítica ante el texto. Acto seguido, aparece la capacidad de distinguir aquello que es fundamental de aquello que es poco relevante en relación a los objetivos de la lectura, esto permite que posteriormente se construya el significado global del texto, y por supuesto, se construyan inferencias, predicciones de lo que se comprendió del texto y sus respectivas conclusiones.

$\mathrm{Y}$, segundo, se encuentra la estrategia estructural; esto se relaciona con los conocimientos previos de una organización retórica que en definitiva favorece la profundización en un determinado texto; y por consiguiente, esto ayuda a que el lector pueda codificar la "información textual con base en las características gráficas, formales y lingüísticas del texto" (p. 51). Para lograr esto, es indispensable conocer los objetivos de la lectura, es decir, el qué, el por qué y el para qué; al mismo tiempo, se necesita activar los conocimientos previos, de manera que para poder comprender lo leído, se requiere establecer conexiones con significado entre aquello que se sabe y los conceptos nuevos.

Lo anterior genera que se "relacionen los conocimientos previos pertinentes con la información que nos aporta el texto a lo largo de toda la lectura" (p.40); de lo cual se asume que el reconocimiento de estas conexiones entre lo que se sabe, y lo nuevo que se aprende con la lectura trae como consecuencia que se asegure la comprensión de lo leído, y con ello se planteen nuevos interrogantes sobre la actividad lectora de ese texto. Así, la actividad lectora contiene en sí la capacidad de que el lector pueda reflexionar sobre la información 
recibida, contrastarla con sus ideas previas; y de esta manera se logra integrar la información recibida en la medida que interactúa el autor, con el texto y el lector.

En consecuencia, se requiere en los procesos de enseñanza y aprendizaje consolidar estrategias de comprensión lectora en los estudiantes, dado que esto coadyuva a generar procesos de lectura autónomos, esto es, lectores capaces de aprender a partir de los textos. Para ello, "quien lee debe ser capaz de interrogarse acerca de su propia comprensión, establecer relaciones entre lo que lee y lo que forma parte de su acervo personal, cuestionar su conocimiento y modificarlo, establecer generalizaciones que permitan transferir lo aprendido a otros contextos" ( Gutiérrez, 2012, p. 34).

Para tal efecto, Gutiérrez, (2012) menciona algunos aspectos a tener en cuenta en la aplicación de las estrategias de comprensión lectora en los procesos de aprendizaje como son: primero, comprender los propósitos explícitos e implícitos de la lectura, esto corresponde a responder a las preguntas: ¿Qué tengo que leer? ¿Por qué/para qué tengo que leerlo? Segundo, "activar y aportar a la lectura los conocimientos previos pertinentes para el contenido de que se trate: ¿Qué sé yo acerca del contenido del texto? ¿Qué sé acerca de contenidos afines que me puedan ser útiles?” (p.35).

Tercero, dirigir la atención a lo que resulta fundamental en detrimento de lo que puede parecer trivial en función de los propósitos que uno persigue; es decir, ¿Cuál es la información esencial que el texto proporciona y que es necesaria para lograr mi objetivo de lectura? ¿Qué informaciones puedo considerar poco relevantes, por su redundancia, por ser de detalle, por ser poco pertinentes para el propósito que persigo? Cuarto, evaluar la consistencia interna del contenido que expresa el texto y su compatibilidad con el conocimiento previo, por ejemplo, ¿ ¿Tiene sentido este texto? ¿Presentan coherencia las ideas 
que en él se expresan? Quinto, comprobar continuamente si la comprensión tiene lugar mediante la revisión y recapitulación periódica y la auto interrogación, es decir, ¿Qué se pretendía explicar en este párrafo - apartado, capítulo-? ¿Cuál es la idea fundamental que extraigo de aquí? y, finalmente, elaborar y probar inferencias de diverso tipo, como interpretaciones, hipótesis y predicciones y conclusiones, a lo cual se originan preguntas como: ¿Cuál podrá ser el final de esta novela? ¿Qué sugeriría yo para solucionar el problema que aquí se plantea? (Gutiérrez, 2012, p.2).

A partir de estos aspectos, es indudable que el proceso de comprensión lectora responde a la coherencia y cohesión de lo que dice el texto para el lector, y posteriormente su adecuada interpretación. Desde esta visión, el autor Tuner explica por qué se requieren de las estrategias en la comprensión lectora, así:

Primero, las estrategias permiten a los lectores elaborar, organizar, y evaluar la información textual; segundo, la adquisición de estrategias de lectura coincide y se solapa con el desarrollo de múltiples estrategias cognitivas para la mejora de la atención, memoria, comunicación y aprendizaje durante la infancia; tercero, las estrategias son controladas por los lectores; estas son herramientas cognitivas que se pueden usar de forma selectiva y flexible; $y$, cuarto, las estrategias de comprensión reflejan la metacognición y la motivación porque lo lectores deben tener tanto conocimientos estratégicos como la disposición a usar dichas estrategias ( Tuner citado por Gutiérrez, 2012, p. 29).

Así pues, la lectura estratégica puede mejorar el aprendizaje en todas las áreas curriculares. Adicionalmente a ello, el autor Sanz (2003) expone algunas técnicas de competencia lectora que son indispensables antes, en el momento y después de leer el texto que facilitan la comprensión del sentido del texto a nivel del micro estructura como de la macro estructura textual. Así pues, dentro de las técnicas de la comprensión lectora se 
encuentran: primero, técnicas para mantener la atención; con esta técnica se pretende que el lector vaya tomando conciencia del hilo de la lectura, para ello se recomienda tomar notas de aquello que se lee. Al mismo tiempo, se busca también que el lector visualice lo que está leyendo, así se mantiene la atención fácilmente.

Segundo, técnicas para trabajar los conocimientos previos; consiste en desencadenar los conocimientos previos que posee el estudiante y que son necesarios para comprender el texto, al respecto se presentan dos modalidades de esta técnica: la modalidad del listado, la cual consiste en que el lector realiza una lista con las ideas que tiene sobre el tema; y también aparece la modalidad de la discusión, a partir de la cual el profesor plantea " una discusión dirigida que pretende sacar a la luz las ideas y experiencias más relevantes para la comprensión del texto" ( Sanz, 2003, p.48).

Tercero, técnica para planear por el texto y descubrir la estructura; esta técnica tiene por finalidad favorecer la lectura global del texto, con lo cual esto permite que el lector desarrolle una idea aproximada de la estructura y del contenido de la lectura. Al respecto, el autor Sanz (2003) establece dos modalidades de esta técnica como son: la modalidad de la mirada panorámica, que consiste en leer el inicio del párrafo, algo del medio y del final, esta modalidad permite que se tenga un primer acercamiento al texto; y también se encuentra la modalidad del atajo, que consiste en "buscar el final para interpretar el conjunto del texto a la luz de la solución final" (p. 50).

Cuarto, aparecen las técnicas para elaborar y reorganizar la información; se presentan una serie de técnicas que sirven para enseñar a los lectores a realizar una lectura activa y a desencadenar estrategias de reelaboración y reordenación de la información del texto. En esta técnica se utilizan mapas conceptuales, preguntas y también mapas 
comparativos que son fundamentales para reestructurar lo que se comprende de la lectura; esto trae como consecuencia la técnica para la síntesis y la identificación de las ideas principales; desde la cual se presenta una síntesis de lo leído del texto, y por tanto, se establecen las ideas centrales y secundarias del texto que en definitiva evidencian la comprensión del texto.

En definitiva, las estrategias y técnicas de comprensión lectora son esenciales en los procesos de enseñanza y aprendizaje en el aula, de manera que el lector tiene la capacidad de desarrollar la competencia lectora a partir de diversas técnicas de lectura que contribuyen a que éste posea un horizonte comprensivo del texto; en esa perspectiva, a continuación se explica la importancia de la comprensión lectora en los procesos de aprendizaje en la escuela.

\subsubsection{La comprensión lectora en los procesos de enseñanza y aprendizaje}

La importancia de la comprensión lectora en los procesos de enseñanza y aprendizaje radica en el sentido que el maestro y sus alumnos pueden compartir progresivamente universos de significados más amplios y complejos, y “dominar procedimientos con mayor precisión y rigor, de modo que unos y otros sean también progresivamente más adecuados para entender e incidir en la realidad" (Lomas, 2014, p. 19). Se trata de un proceso de construcción conjunta- maestro- estudiante-, en la medida que, cuando el alumno sea el protagonista principal, el profesor tendrá también un papel destacado en la competencia lectora. En otros términos, esto se constituye en un proceso de participación guiada, cuya finalidad supone “situación educativa en la que se ayude, en primer lugar, al alumno a contrastar y relacionar su conocimiento previo con el que le va a resultar necesario para abordar dicha situación" (p.20). Y, en segundo lugar, el alumno dispone desde el principio -porque el profesor lo facilita- de una visión de conjunto o estructura general para llevar a cabo su tarea. 
Mientras para el autor Cesar Coll, 1990), la planificación del proceso de enseñanza y aprendizaje de la competencia lectora conlleva los siguientes aspectos a saber: primero, los contenidos que hay que enseñar. En el caso de la comprensión lectora, "se trata de enseñar los procedimientos estratégicos que pueden capacitar a los alumnos para leer de forma autónoma y productiva, es decir, utilizando la lectura para aprender y controlar que ese aprendizaje se realiza" (Coll citado por Lomas, 2014, p.14). Segundo, los métodos de enseñanza; se pretende buscar las situaciones más adecuadas para que los alumnos puedan construir su conocimiento y aplicarlo en contextos diversos. Tercero, la secuenciación de los contenidos; es decir, "ayudar a los alumnos a aprender supone ayudarles a establecer el máximo número de relaciones entre lo que ya saben y lo que se les ofrece como nuevo" (p.15). Cuanto más general y simple sea la nueva información, más sencillo resultará dicho proceso, puesto que se espera que el alumno pueda relacionar su conocimiento previo con algo poco específico, detallado y complejo cuando ya posea un marco explicativo sobre lo más general. Y, finalmente, la organización social del aula; en el caso de la enseñanza de la lectura, es habitual que el profesor plantee las preguntas a un gran grupo; o que los ejercicios de extensión de la lectura se realicen individualmente, de ahí la importancia de generar procesos de enseñanza en los cuales el profesor de manera armónica en el aula de clase ofrezca variados aspectos didácticos que faciliten una mejor comprensión de la lectura; y en consecuencia, se consolide un aprendizaje que tenga como fundamento en la competencia lectora el pensamiento crítico. 


\section{CAPÍTULO 3: LA LECTURA LITERARIA DE LA NOVELA HISTÓRICA EN LOS DOCUMENTOS REFENTES DEL MEN}

El presente capítulo tiene por finalidad, revisar cómo en los lineamientos curriculares se vincula la lectura literaria de la novela histórica en los planes lectores, mallas curriculares y Derechos Básicos de Aprendizaje DBA, en las instituciones educativas. Para tal propósito, en un primer momento se abordan algunos aspectos centrales de la lectura literaria en la novela histórica según los lineamientos del MEN; en un segundo momento, lo relacionado a los estándares básicos de competencias de lenguaje en los grados 8 y 9 de educación media. En un tercer momento, los derechos básicos de aprendizaje; y, cuarto momento lo que concierne a los planes de lectura literaria en las instituciones educativas Tabora I.E.D ubicado en la Localidad $10^{\circ}$ Engativá y Fabio Lozano Simonelli de la Localidad $5^{\circ}$ Usme.

Primer momento: la lectura literaria en la novela histórica según los lineamientos del MEN

En relación a los lineamientos curriculares del MEN (2013), el cual tiene por finalidad plantear unas ideas básicas que sirvan de apoyo a los docentes en sus definiciones referentes al desarrollo curricular, dentro de los Proyectos Educativos Institucionales. De esta manera, el documento resalta el papel de la historia de la literatura como un paso en la consolidación del reconocimiento de la interculturalidad en los sujetos. Por tanto, de lo que se trata es más bien de buscar diversas alternativas al trabajo curricular dentro de los PEI, en los cuales se promueva la lectura literaria de obras históricas. A continuación, aparecen dos novelas 
históricas que recogen la importancia de la lectura literaria en la novela histórica de la siguiente manera:

\section{Tabla 3: Lineamientos Curriculares del MEN}

\begin{tabular}{|c|c|c|}
\hline \multicolumn{3}{|c|}{ LECTURA LITERARIA DE NOVELAS HISTÓRICAS } \\
\hline $\begin{array}{l}\text { JUAN RULFO- PEDRO } \\
\text { PÁRAMO }\end{array}$ & LA ODISEA- HOMERO & INTERPRETACIÓN TEXTUAL \\
\hline $\begin{array}{c}\text { Esta novela compleja en su } \\
\text { estructuración enunciativa pero } \\
\text { breve en su extensión. Dicha } \\
\text { estructuración narrativa (el } \\
\text { contrapunto narrativo, la } \\
\text { digresión, los puntos de vista, la } \\
\text { ambigüedad de las voces, } \\
\text { etcétera) puede respaldar el } \\
\text { criterio sobre el grado más } \\
\text { adecuado para abordar su lectura } \\
\text { literaria } \\
\text { mostrados por los antiguos poetas } \\
\text { griegos y latinos. Mitos } \\
\text { universales como la destrucción y } \\
\text { los grandes mitos universales, ya } \\
\text { (especie de biografía) de los } \\
\text { protagonistas (Juan Preciado y } \\
\text { Pedro Páramo) nos remite a } \\
\text { varios tópicos literarios, presentes } \\
\text { en muchas obras universales. Así, como lo ha } \\
\text { prón }\end{array}$ & $\begin{array}{l}\text { En aras de la singularidad en el } \\
\text { análisis (evitando tanta } \\
\text { generalización, como sea posible } \\
\text { y, sobre todo, privilegiando la } \\
\text { lectura de los textos mismos), } \\
\text { podríamos seleccionar un tópico, } \\
\text { como el viaje del hijo en busca } \\
\text { del padre. Algunos críticos han } \\
\text { llamado a este tópico “la } \\
\text { telemaquia”, en una remisión a la } \\
\text { obra de la Odisea en Homero. } \\
\text { En la tradición crítica se ha } \\
\text { entendido por “telemaquia” al } \\
\text { proceso narrativo a través del } \\
\text { cual se desarrollan las peripecias, } \\
\text { ctelemaquia” viene del análisis de } \\
\text { conflictos, luchas y sufrimientos } \\
\text { en el peregrinaje del adolescente, } \\
\text { a quien se le impone la búsqueda } \\
\text { del padre, búsqueda que a la vez } \\
\text { es búsqueda de identidad, o } \\
\text { bura del personaje } \\
\text { la Odisea, epopeya del Otro. }\end{array}$ & $\begin{array}{l}\text { Varios críticos ya han señalado en la } \\
\text { novela de Rulfo la presencia de la } \\
\text { “telemaquia”, su representación simbólica } \\
\text { en la historia de Juan Preciado. Entre } \\
\text { estos críticos cabe mencionar a Julio } \\
\text { Ortega (1969) y a Carlos Fuentes. } \\
\text { Siguiendo a Fuentes, Juan Preciado, el } \\
\text { hijo de Pedro Páramo, llega a Cómala: } \\
\text { como Telémaco, busca a Ulises. Un } \\
\text { arriero llamado Abundio lo conduce. El } \\
\text { Caronte y el Estigio que ambos cruzan es } \\
\text { un río de polvo. Abundio se revela como } \\
\text { hijo de Pedro Páramo y abandona a Juan } \\
\text { Preciado en la boca del infierno de } \\
\text { Comala. Juan Preciado asume el mito de } \\
\text { Orfeo: va a contar y va a cantar mientras } \\
\text { desciende al infierno, pero a condición de } \\
\text { no mirar hacia atrás. }\end{array}$ \\
\hline
\end{tabular}




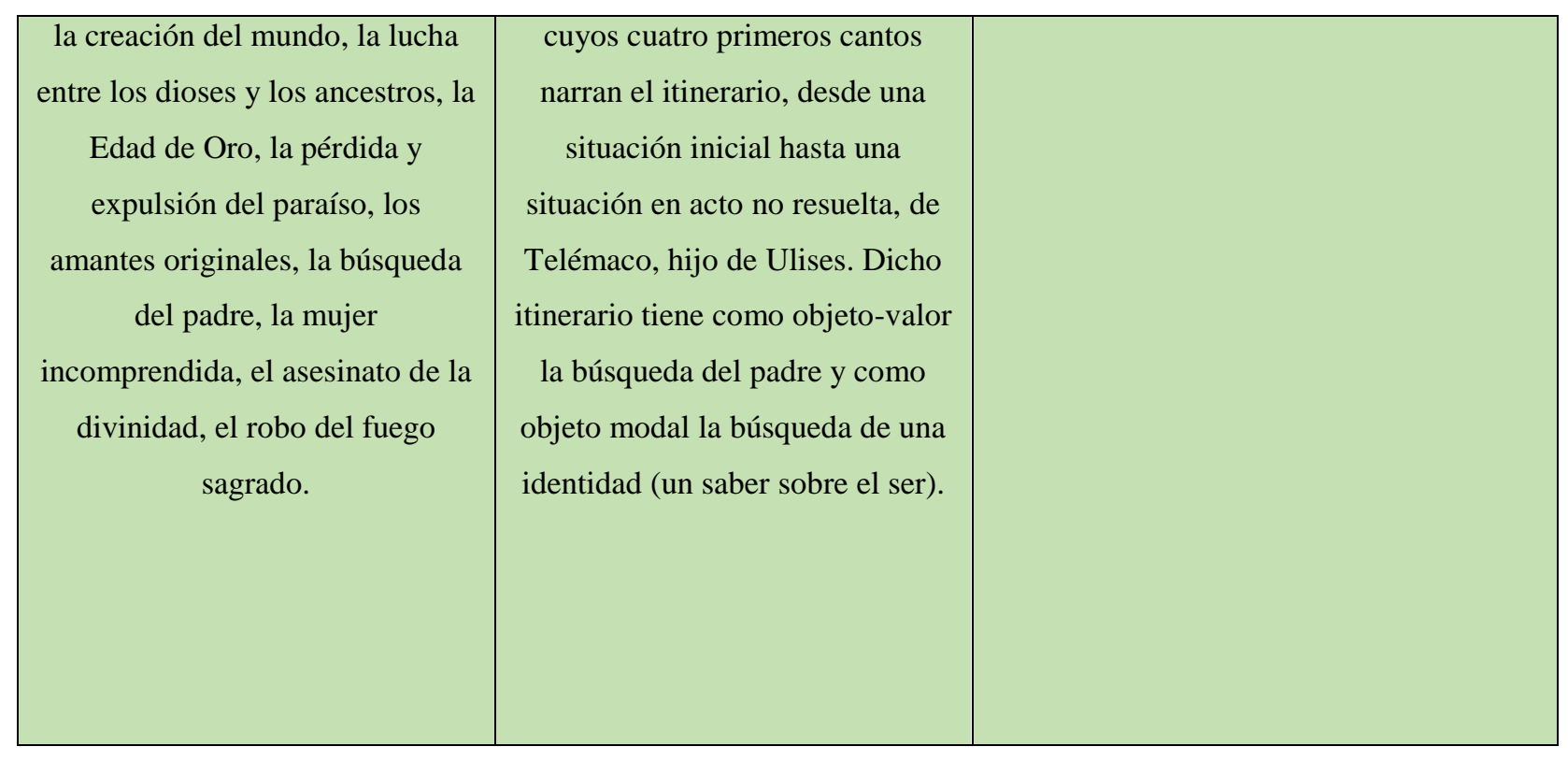

Fuente: MEN (2013)

Con base en los aportes de los lineamientos curriculares del MEN ( 2013), el cual desarrolla en lo que respecta al proceso de enseñanza de la literatura la necesidad de implementar la lectura literaria en dos novelas históricas a saber: La novela contemporánea Pedro Páramo del autor Juan Rulfo, y la novela histórica de la Odisea, de Homero. Estas dos novelas históricas son parte de un estudio comparativo de la interrelación que se da en la obra de la Odisea con la obra literaria Pedro Páramo.

Para ello, se explica las diferencias y similitudes en estas dos novelas históricas. Por ejemplo, en el caso de Pedro Páramo se evidencia en su relato como Juan fracasa en la consecución del objeto-valor; mientras, en la Odisea se recurre al Telémaco en la medida que se da una búsqueda la cual queda suspendida y sólo se resolverá positivamente hacia el final. Pero también hay disimilitud en el entorno espacial-simbólico al que pertenecen los personajes. Así, en Telémaco (la Odisea) se trata, de cierto modo, de un viaje plano, sin tropiezos graves, un viaje realizado con la sobreprotección de la diosa, un viaje sin terrores. 
En Juan Preciado, al contrario, se trata de un descenso al mundo de los muertos y de las sombras (al que desciende Ulises, más no Telémaco), donde "el aire sopla caliente y está "envenenado por el olor podrido de las saponarias" y donde la llanura "parece una laguna transparente, deshecha en vapores por donde se traslucía un horizonte gris" (el Estigia griego)" (MEN, 2013, p.39)

En resumen, estas similitudes y diferencias en estas dos novelas históricas, de épocas distintas dilucidan la importancia de la lectura literaria de las novelas históricas en la medida que se reconfiguran los hechos históricos en las narraciones de estas obras históricas, y de esta manera se resignifica el papel de la lectura literaria de la novela histórica en los procesos de enseñanza.

Segundo momento, lo relacionado a los estándares básicos de competencias de lenguaje

A continuación, aparecen los Estándares Básicos de Competencias de Lenguaje para los grados 8 y 9 grado de educación media en lo que respecta a la lectura literaria de la novela histórica desde tres aspectos: finalidad, aspectos de la enseñanza y comprensión e interpretación textual, como se evidencia en la siguiente matriz: 


\section{Tabla 4: Estándares Básicos de Competencias de Lenguaje}

\begin{tabular}{|c|c|c|}
\hline OBJETIVO & ASPECTOS DE LA ENSEÑANZA & $\begin{array}{l}\text { COMPRENSIÓN E } \\
\text { INTERPREACIÓN TEXTUAL }\end{array}$ \\
\hline $\begin{array}{l}\text { Determinar en las obras literarias } \\
\text { latinoamericanas, elementos } \\
\text { textuales que dan cuenta de sus } \\
\text { características estéticas, históricas y } \\
\text { sociológicas. }\end{array}$ & $\begin{array}{l}\text { Conozco producciones literarias de } \\
\text { la tradición oral latinoamericana. } \\
\text { Leo con sentido crítico obras } \\
\text { literarias de autores } \\
\text { latinoamericanos. } \\
\text { Establezco relaciones entre obras } \\
\text { literarias latinoamericanas, } \\
\text { procedentes de fuentes escritas y } \\
\text { orales. } \\
\text { de diferentes épocas y los comparo } \\
\text { con los empleados por autores de } \\
\text { otros contextos históricos. } \\
\text { Identifico los recursos del lenguaje } \\
\text { empleados por los autores } \\
\text { momentos de la literatura } \\
\text { latinoamericana, atendiendo a } \\
\text { particularidades geográficas, de } \\
\text { género, de autor. }\end{array}$ & $\begin{array}{l}\text { Comprendo el sentido global de cada } \\
\text { uno de los textos que leo, la } \\
\text { intención de quien los produce y las } \\
\text { características del contexto en las } \\
\text { cuales se produce. } \\
\text { Comprende los factores socios } \\
\text { culturales que determinan algunas } \\
\text { manifestaciones del lenguaje no } \\
\text { verbal. } \\
\text { personas y las comunidades que las } \\
\text { produjeron } \\
\text { Interpreto manifestaciones artísticas } \\
\text { no verbales y las relaciono con las } \\
\text { sociales en diversas manifestaciones } \\
\text { del lenguaje no verbal. }\end{array}$ \\
\hline
\end{tabular}

Fuente: MEN (2003)

Según el cuadro anterior que representa algunos aspectos centrales de los estándares de competencias del lenguaje en los grado 8 y 9 de la educación media, en lo que respecta a 
la lectura de la novela histórica en los procesos de enseñanza se encontró: primero, se rescató en el proceso de enseñanza que los estudiantes conozcan las obras latinoamericanas, sus elementos textuales a partir de sus características históricas y estéticas; a su vez, la importancia de conocer producciones literarias- como es el caso de las novelas históricas- de tradición oral latinoamericana. Segundo, se incentiva a la comunidad estudiantil a leer con sentido crítico las obras literarias de autores latinoamericanos, y por consiguiente, se logre discriminar los principales momentos de la literatura latinoamericana. Y, tercero, surge la necesidad de identificar los recursos del lenguaje empleados por los autores latinoamericanos de diferentes épocas ${ }^{12}$.

En definitiva, los estándares de competencias de lenguaje para los grados 8 y 9 en lo que corresponde a la lectura de las novelas históricas evidenció la necesidad de generar procesos de enseñanza, en, los cuales se promueve el conocimiento de las obras literarias latinoamericanas, con la finalidad de conocer el lenguaje, el contexto histórico, y además de ello, que el estudiante desarrolle un sentido crítico de la lectura literaria de las obras latinoamericanas. No obstante, en este apartado no se encontró una profundización en las competencias de lenguaje que se requiere para la novela histórica.

Tercer momento, los derechos básicos de aprendizaje;

Acto seguido, se encuentran los Derechos Básicos del Aprendizaje, en relación a los aportes de la lectura literaria en las obras históricas:

\footnotetext{
${ }^{12}$ Como aparece en la Marquesa de Yolombó: Si no hiciera sido por el quereme, yo no hubiera cogido a este, con toito lo enamorado y lo perro que era" (p. 83).
} 


\section{Tabla 5: Derechos Básicos del Aprendizaje}

\begin{tabular}{|c|c|}
\hline ASPECTOS DEL PROCESO DE ENSEÑANZA & EJEMPLOS \\
\hline $\begin{array}{l}\text { Reconoce en las producciones literarias como } \\
\text { cuentos, relatos cortos, fábulas y novelas, aspectos } \\
\text { referidos a la estructura formal del género y a la } \\
\text { identidad cultural que recrea. } \\
\text { Identifica las estrategias narrativas del autor para } \\
\text { relatar su perspectiva sobre lo que ha ocurrido en } \\
\text { una región. } \\
\text { Construye el sentido de los textos literarios con } \\
\text { base en las interacciones que sostiene con las } \\
\text { comunidades de lectores y escritores a las que } \\
\text { pertenece. } \\
\text { Determina la identidad cultural presente en textos } \\
\text { literarios y la relaciona con épocas y autores. } \\
\text { Distingue las estructuras formales de textos } \\
\text { literarios como la presencia de diferentes narradores } \\
\text { que se encargan de nutrir la historia con diferentes } \\
\text { puntos de vista sobre un suceso }\end{array}$ & $\begin{array}{l}\text { Lee textos }{ }^{13} \text { literarios que contienen sucesos que han ocurrido } \\
\text { en una región (por ejemplo, la novela Leopardo al Sol de } \\
\text { Laura Restrepo). } \\
\text { Analiza las características propias de un texto como el } \\
\text { narrativo: voz que narra, punto de vista de dicha voz, tipos de } \\
\text { personajes, lugar, tiempo, orden la historia, recursos como la } \\
\text { descripción o el diálogo, entre otras. }\end{array}$ \\
\hline
\end{tabular}

Fuente: (MEN) 2015

Según los Derechos Básicos de Aprendizaje en relación a la lectura literaria de novelas históricas se evidenció en el proceso de aprendiza con los estudiantes la necesidad que el estudiante reconozca las producciones literarias como cuentos, novelas, fábulas, aspectos

\footnotetext{
${ }^{13}$ Por ejemplo, esto se evidencia en la Marquesa de Yolombó: Durante siete días, nadie asomaba por esos palacios encantados de la luna de miel; pero, a la octava noche, despertaban a los recién casados con la serenata ritual. Música y letra la componían todos los entendidos en estas artes chuscas, que no eran pocas, en este pueblo de bromistas desocupados. Tales serenatas, tenían que ser según lo tradicional (p.74).
} 
referidos a su estructura formal y la identidad cultural. A su vez, la capacidad del estudiante de reconocer los diferentes narradores que nutren la historia en las novelas.

A continuación, aparecen los planes de estudio de las instituciones educativas Tabora I.E.D ubicado en la Localidad $10^{\circ}$ Engativá y Fabio Lozano Simonelli de la Localidad $5^{\circ}$ Usme, en los cuales se resaltan los aportes de la lectura literaria a la novela histórica en los grados 8 y 9 .

Cuarto momento los planes de lectura literaria en las instituciones educativas Tabora I.E.D y Fabio Lozano Simonelli de la Localidad $5^{\circ}$ Usme.

A continuación se encuentran los Planes de estudios de los colegios, Tabora y Fabio Lozano Simonelli, los cuales desarrollan algunos aspectos esenciales de la lectura literaria de la novela histórica, a partir de los contenidos que establece el Plan, y las competencias de aprendizaje que se propone la institución educativa en los estudiantes del grado 8, así: 
La Marquesa de Yolombó: Una propuesta didáctica de la Lectura Literaria. 59

Tabla 6: Plan de estudios- Colegio Tabora.

\begin{tabular}{|c|c|}
\hline CONTENIDOS & COMPETENCIAS DE APRENDIZAJE \\
\hline $\begin{array}{c}\text { Octavo grado: Literatura del descubrimiento y } \\
\text { conquista. } \\
\text { Colonia e Independencia. } \\
\text { Antecedentes. } \\
\text { Obras. }\end{array}$ & $\begin{array}{c}\text { Reconoce las características generales de los géneros } \\
\text { literarios e identifica los elementos de la literatura indígena } \\
\text { colombiana. }\end{array}$ \\
& $\begin{array}{c}\text { Conoce y analiza fenómenos y aspectos que caracterizan el } \\
\text { desarrollo de la literatura colombiana en el descubrimiento, } \\
\text { conquista y colonia. }\end{array}$ \\
& $\begin{array}{c}\text { Conoce y analiza fenómenos que caracterizan el desarrollo } \\
\text { de la literatura colombiana en la época de la Independencia. }\end{array}$ \\
\hline
\end{tabular}




\section{La Marquesa de Yolombó: Una propuesta didáctica de la Lectura Literaria. 60}

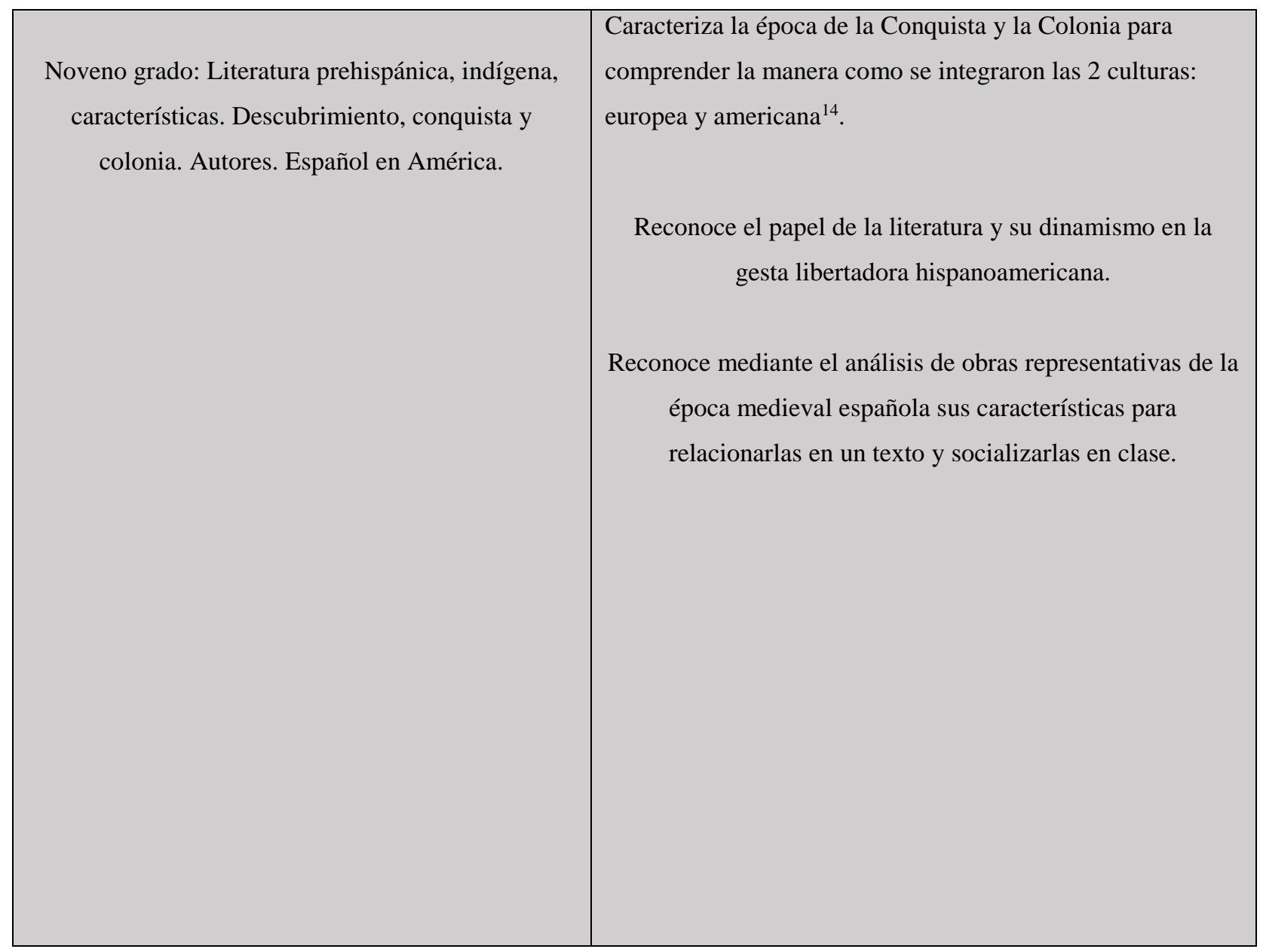

Fuente: Plan de estudios, Colegio Tabora, 2017.

De acuerdo al plan de estudios del Colegio Tabora, en lo que respecta a la lectura literaria sobre las obras históricas se evidenció que tanto en el grado octavo y noveno se propone en los estudiantes que conozcan la literatura del descubrimiento y la conquista (colonia- e independencia), de manera que el estudiante se apropie de estos textos históricos

${ }^{14}$ La religión católica, alma mater de la Colonia, tenía allí emporio tan pujante, que, a más de la fundadora, había levantado dos iglesias. Los fieles cumplían estrictamente los cinco mandamientos y todo indio o liberto que se hiciese el remiso para asistir al "incruento sacrificio" lo arreaban a latigazos hasta la propia puerta de la iglesia. Algo semejante le acontecía a quien se obstinaba en no pagar el diezmo”(Pág. 74) 
de literatura, y genere con esto un sentido crítico del proceso de colonización en Latinoamérica. Mientras en el caso del grado noveno de la institución educativa.

\section{Tabla 7: Plan de estudios- Colegio Fabio Lozano Simonelli}

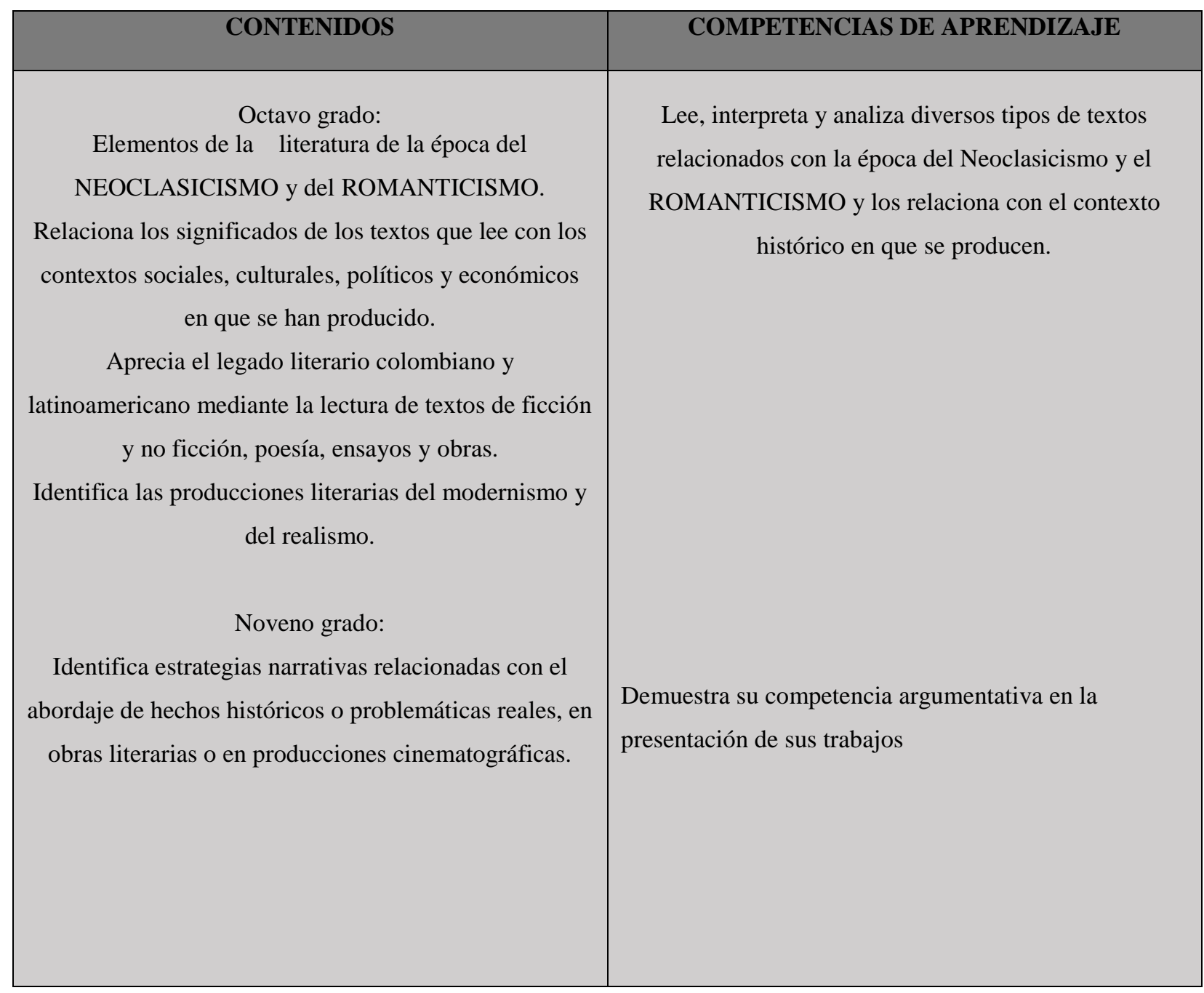

Fuente: Plan de estudios, Colegio Fabio Lozano, 2018

En el plan de estudios del Colegio Fabio Lozano Simonelli, en lo que concierne a los grados octavo y noveno se encontró que la lectura literaria sobre la novela histórica se 
encuentra enmarcada dentro de la literatura de la época del neoclasicismo y el romanticismo; y también se desarrolla la comprensión e interpretación de obras literarias dentro del legado colombiano y latinoamericano, en lo que respecta a textos de ficción, poesía y obras históricas.

A modo conclusivo, se encontró dentro de la lectura literaria de la novela histórica en el caso de los lineamientos curriculares del MEN (2013), se constató la importancia de promover la lectura literaria a partir de estudios comparados, desde dos obras históricas (Pedro Páramo y la Odisea), para resignificar que estas novelas históricas contienen elementos textuales e interpretativos similares que contribuyen a comprender la importancia de la lectura literaria en estas obras, y así el estudiante desarrolle un sentido crítico y argumentativo en su proceso de enseñanza y aprendizaje de la lectura literaria.

En relación a los Estándares Básicos de Competencias de Lenguaje, de los grados 8 y 9, se encontró: primero, se rescató en el proceso de enseñanza que los estudiantes conozcan las obras latinoamericanas, sus elementos textuales a partir de sus características históricas y estéticas; y, segundo, la necesidad de incentivar en la comunidad estudiantil a leer con sentido crítico las obras literarias de autores latinoamericanos.

Por su parte, sobre los Derechos Básicos de Aprendizaje en los grados 8 y 9, específicamente de la lectura literaria de novelas históricas se evidenció en el proceso de aprendizaje con los estudiantes la necesidad que el estudiante reconozca las producciones literarias como cuentos, novelas, fábulas, aspectos referidos a su estructura formal y la identidad cultural, y también la capacidad del estudiante de reconocer los diferentes narradores que nutren la historia en las novelas.

Para finalizar, aparece el plan de estudios del Colegio Tabora, el cual propone que los estudiantes de octavo y noveno grado conozcan la literatura del descubrimiento y la 
conquista (colonia- e independencia), de manera que el estudiante se apropie de estos textos históricos de literatura, y genere con esto un sentido crítico en la apropiación de estas obras literarias. Y, en el plan de estudios del Colegio Fabio Lozano Simonelli, se pudo entrever que la lectura literaria sobre la novela histórica se encuentra enmarcada dentro de la literatura de la época del neoclasicismo, el romanticismo, y obras literarias del legado colombiano; esto conlleva a que el estudiante desarrolle la comprensión e interpretación de obras literarias, para consolidar un pensamiento argumentativo y crítico con base en la lectura de estas novelas que se desarrollan en estas épocas de la historia. 


\section{CAPITULO 4: PROPUESTA DIDÁCTICA}

Este capítulo tiene por finalidad, realizar una propuesta didáctica que permita el abordaje de la novela histórica la Marquesa de Yolombó. Ya que, el presente trabajo cobra importancia y debe su razón de ser a la manera como un proceso de análisis puede ayudar en la comprensión desde lo histórico y literario a una obra clásica colombiana; mediante el cual se vislumbra realizar una didáctica de la lectura de un texto del género novela en la obra La Marquesa de Yolombó del autor Tomas Carrasquilla. Para este propósito, en un primer momento se abordan las categorías que se encontraron en la Marquesa de Yolombó; en un segundo momento, la didáctica en los procesos de enseñanza y aprendizaje, es decir, la didáctica de la literatura, la didáctica de la lectura literaria y la didáctica crítica de la lectura literaria. En un tercer momento, las estrategias de la lectura literaria; y, finalmente, la propuesta de la secuencia didáctica con base en la Marquesa de Yolombó.

\subsection{Categorías centrales en la Marquesa de Yolombó}

En este apartado se exponen las categorías centrales de la Marquesa de Yolombó, de las cuales se pretende realizar un acercamiento interpretativo de cada categoría con algunos fragmentos de la obra. Las categorías que emergen en la obra son: la reivindicación de lo femenino; el costumbrismo; el lenguaje y el sincretismo étnico cultural.

\subsubsection{La reivindicación de lo femenino}

Amalia Franco Castaño en el año 2013 realiza un artículo de reflexión en torno a la obra de Tomás Carrasquilla denominado: “ La voz del Personaje femenino en la construcción de una 
posición realista crítica desde La Marquesa de Yolombó de Tomás Carrasquilla” una época concreta en Colombia y por supuesto, la estrecha relación de los personajes femeninos con la postura crítica de Carrasquilla frente al proyecto del llamado Modernismo en Colombia "La actitud antimodernista de la Iglesia, la perpetuación de un sistema de gobierno de corte conservador y la exclusión de ciertos sectores de la sociedad hicieron del proyecto moderno en Colombia una propuesta inacabada e incompleta, resultado de la parcialización y contradicción" (Franco, 2013.p.19)

Para Amalia Franco el realismo crítico de Carrasquilla se hace evidente en el personaje de Bárbara Caballero, su voz manifiesta la duda que tiene el autor en la transparencia del lenguaje, La marquesa con un lenguaje directo y fiel a las doctrinas de la iglesia expone las injusticias del entorno, un leguaje contrario a los postulados de la "cultura letrada" que Miguel A. Caro promovía. La voz del Personaje femenino en la construcción de una posición realista crítica construye desde la referencialidad (alusiones directas de la época colonial, republicana, de los siglos XVIII y XIX)

Tomas Carrasquilla cuenta en su obra, la vida de la criolla Bárbara desde que, a los dieciséis años, quiere ser minera, hasta que se enriquece, obtiene de Carlos IV el título de Marquesa, es víctima de un pillo que la desposa para robarle los caudales de oro, pierde la razón y la recobra en la ancianidad; se trata de la historia de una mujer que es emancipada en esa época histórica, y que por pertenecer ella como mujer al grupo de los excluidos sociales, tales como los esclavos. Sin embargo, su conciencia, la lucidez y la claridad de la que goza el personaje cuando "se autoevalúa y se sitúa en su contexto, tanto en el esplendor dela época colonial como en el período de ruptura de dicho orden y la avanzada en el terreno de unos nuevos valores que inaugura la pre modernidad (Arango, 2014, p. 13). 
El personaje principal que da título a la novela, Bárbara Caballero, propone los nuevos valores que van surgiendo en el Nuevo Mundo, y que el autor da a conocer a los lectores. De ahí que Tomas Carrasquilla a través del personaje de Bárbara evidencia la necesidad de la reivindicación de los valores femeninos, en contraposición a las situaciones de exclusión y desigualdad social en ese momento histórico, como aparece a continuación:

\section{Fragmento 1:}

Yo trabajaría en cualquier cosa, con alma, vida y corazón, como cualquier hombre; pero bien sabe, su Merced, que a las blancas no nos enseñan nada de servir. Nos tienen de ociosas, de bonitas. $\mathrm{Ni}$ aun en la casa movemos una paja, porque las negras lo hacen todo. Ahí nos ponen a hilar o a coser cualquier trapo, por matar el tiempo, porque eso ¿qué oficio va a ser para una persona grande, que no sea boba ni loca? $\underline{\text { Nos }}$ crían para ser un tronco de carne, un arnaco inútil. [...] ¡Es una desgracia ser señora! Para más son las negras esclavas, que para algo sirven (Carrasquilla, 1952, p. 129).

Del fragmento anterior se evidencian dos realidades de la importancia de reivindicar lo femenino a través del personaje de Bárbara: primero, la necesidad de que a la mujer se le reconozca su capacidad de trabajar y ser valorada en la sociedad; es decir, se trata de dignificar el papel de la mujer en la sociedad, y esto se consigue a partir de la lucha por igualdad de condiciones de una vida digna; así aparece en la narración: 


\section{Fragmento 2:}

Ellas sirven para convencer a Doña Rosalía, madre de Bárbara Caballero, para que ceda en sus empeños de permitirle irse a trabajar a las minas, una tarea a todas luces de hombres y negros (p.120).

Y, segundo, el autor muestra el contexto social en el cual se desarrolla el personaje de Bárbara, en el cual se cosifica a la mujer. Por otra parte, reivindicar lo femenino conlleva la necesidad la legitimación de igualdad de condiciones tanto para hombres como mujeres, en ese aspecto, Bárbara representa la avidez de conseguir todo lo que se propone como lo narra el autor:

\section{Fragmento 3:}

$\underline{\text { Si no esta pasión, base de la vida, otras hartas avasalladoras del humano sentimiento: }}$ eran la sed de oro, el ansia de aventuras, esas fiebres herederas de los conquistadores españoles, y que, por un capricho o una ironía de las leyes ancestrales resurgían, poderosas, en una hembra (p.68).

Bárbara es poderosa, de heredad abundante, a todas luces de posición privilegiada, y ciegamente monárquica. Es así como durante la Colonia (fines del siglo XVIII) Bárbara se mantiene unida a la corona a través de un símbolo, su título de Marquesa; sin embargo, a medida que la imagen del Rey comienza a deslegitimarse, la protagonista revela actitudes y pensamientos distintos para la época, que, aunque no la separan de su compromiso religioso, le permiten modificar relativamente ciertos pre juicios sociales (Franco, 2013.p.21), se trata de reivindicar los derechos de la mujer como aparece en el siguiente fragmento: 
Fragmento 4:

Ocurrírsele a una joven, de aquella época y en aquel medio, tan extrañas y progresistas invenciones, es caso muy personal y peregrino. El solo hecho de aprender a leer y $\underline{\text { escribir de aquel modo y en las colonias españolas de entonces, implica fuerza de }}$ entendimiento y voluntad, facultades especialísimas para iniciar y más aún para arbitrar; que esta ignorancia en que vivían los súbditos del Rey, en estas sus Batuecas de América, no era tanto por el sistema colonial, cuanto por la época, la distancia, la imposibilidad (p. 132).

Es decir, que la Marquesa de Yolombó representa la reivindicación de la lucha por los derechos de la mujer en esa época, y a partir de su visión emprendedora logra visibilizar en ese contexto social la importancia de reconocer y la valor la dignidad de la mujer en la sociedad, se trata de una afirmación personal de la Marquesa por los valores de las mujeres, en contra del poder hegemónico de la época, en el cual la dominación patriarcal ejercía control sobre la sociedad. Por eso, más allá de interpretar esta resolución como una situación de incomprensión del personaje y de su naturaleza femenina, es posible leer también cómo la integración de un proyecto libertario; de ahí que las premisas de emancipación y libre pensamiento, que caracterizan al personaje, se convierten en principios democráticos de la sociedad, y además se transforma en una propuesta política, desde la postura crítica que posee esta novela histórica en la medida que se revindican los derechos de lo femenino. 


\subsubsection{El costumbrismo}

La Marquesa de Yolombó es una novela histórica que reconstruye el pasado de una población antioqueña en el siglo XVIII, a fines de la Colonia y principios de la Independencia “todos pertenecen en efecto al pasado: los criollos, la protagonista, las negras, mestizas o blancas, todos son hermanos de los personajes de las novelas contemporáneas, y hablan y obran como ellos” (Forero, 2008, p. 89), esto se evidencia en el siguiente fragmento:

Fragmento 1:

En el Congo hubiera sido reina, y de reyes descenderá, probablemente. Es una criatura tan negra, de un negro tan fino y tan lustroso, de formas tan perfectas, de facciones tan pulidas, que parece tallada en azabache, por un artista heleno (p.98).

En este fragmento se constata cómo en esta novela histórica el autor desarrolla enfatiza sobre las mezcla de razas en esta población antioqueña; igualmente se muestran algunas costumbres de la población, por ejemplo:

Fragmento 2:

Varias de aquellas señoronas, vestidas de puntos y rengues, bastante más escotadas que las actuales, si más lenguas de faldas, no pueden sostenerse en aquellos zapatos empinados de raso (p. 145).

En este fragmento se constata cómo vestían las mujeres elegantes en este pueblo antioqueño; como también Carrasquilla enfatiza en temas como el matrimonio en esta población, así lo evidencia el siguiente fragmento:

Fragmento 3:

Los matrimonios eran fiestas públicas, con matanzas de terneros y de cerdos son contar las carnicerías en montes y corrales; y todo a expensas de padres y padrinos de ambos contrayentes. A la novia la sacaban hecha un altar, la coronaban de cualquier flor y le ponían 
siempre el velo de castidad. La madrina ritual camarera de honor, estaba a la vela todo el día, para ponerle el coronamiento y hacerle mudar de galas, tantas veces cuantas fuesen las vestimentas que para el caso se tuvieran preparadas. Aquel revestirse arreo constituía el lujo supremo de casaderas y casadas.

Por tanto, era costumbre de la comunidad de Yolombó realizar toda celebración ritual en torno al matrimonio, en el cual la comida, los vestidos, y los padrinos eran aspectos centrales de las costumbres de esta población antioqueña.

\subsubsection{El lenguaje}

Para el autor Osorio (2003) la noción del lenguaje aparece como mecanismo de transmisión de una tradición oral y escrito entre las sociedades; mientras, la lengua es el lugar en el cual se desarrolla con efectividad nuestra disidencia con nuestro destino "por medio de inversiones, retruécanos, parodias, y permitir así que las energías vernáculas se enfrenten con terminologías reverenciadas" (Said, citado por Osorio, 2008, p.208). En esa perspectiva, Osorio (2003) explica la manera como Carrasquilla en su única novela histórica, ilumina el proceso de construcción de una lengua nacional, con base en elementos culturales, lingüísticos propios del territorio Antioqueño, por ejemplo:

Fragmento 1:

Lo más particular era que Peralta con tantísimo caudal como iba consiguiendo no se daba nadita di importancia, ni en la ropita, ni en la comida ni en nada: con su misma $\underline{\text { ruanita pastusa de listas azules, }}$, con sus mismitos calzones fundillirrotos (p.90). 
En este fragmento se evidencia cómo "la ruanita pastusa de listas azules", es un elemento lingüístico esencial de la idiosincrasia antioqueña; igualmente, cuando menciona los “calzones fundillirrotos" que es un lenguaje propio de esa población antioqueña.

Osorio concluye de la siguiente manera a propósito de la función del lenguaje en la novela La Marquesa de Yolombó.

Fragmento 2:

La lengua que Carrasquilla les otorga a sus personajes, responde la urgencia de circunstancias históricas, no es un ornamento, ni un ejercicio nostálgico, es una práctica integral que posibilita los debates del siglo XX pleno de incertidumbres contradicciones y desafíos. El humanismo de Carrasquilla cree en las capacidades de los seres humanos para luchar por sus utopías (...). Su apuesta lingüística saca el español de la biblioteca, la tertulia, la Academia de la Lengua, lo hace vibrar en la voz de Peralta, de Bárbara Caballero y de muchos otros personajes inolvidables, no como arqueología, sino ligada a la vida misma (Osorio, 2008, p. 213)

Es decir, que se da una interrelación entre el lenguaje y la práctica de la vida misma, lo que viven sus personajes, como aparece en el siguiente fragmento: Fragmento 3: "Si no hiciera sido por el quereme, yo no hubiera cogido a este, con toito lo enamorado y lo perro que era" (p. 83).

\subsubsection{El sincretismo étnico cultural}

Catalina Restrepo de la Universidad de Antioquia llamado "Cantos e interacción cultural en la Marquesa de Yolombó de Tomás Carrasquilla” (2003), un artículo enfocado a presentar la dimensión intercultural de la novela desde una perspectiva estética y antropológica sobre 
La Marquesa de Yolombó: Una propuesta didáctica de la Lectura Literaria. 72

los cantos negros y andaluces y como antecedente colonial del folclore antioqueño incorporado en la narrativa. De hecho, se observa en la obra cómo la música, el verso y la danza como elementos constantes que vivifican la religiosidad y la mixtura cultural constitutiva de Yolombó, como aparece a continuación:

\section{Fragmento 1:}

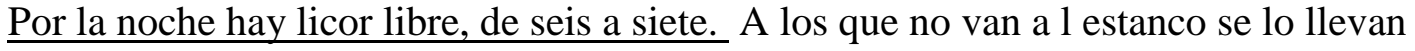
a donde estén; hay refresco bailable en casa de la anfitriona. Pone la contradanza, aprendida en Antioquia; luego, acompañada de Narcisa, saca las tonadillas y los bundes, los arpegios y panderetas, que se tenían atan guardados. La beldad africana, habituada a estas exhibiciones artísticas, se muestra, si muy en ello, muy en su puesto de negra y de esclava voluntaria. No sabe la hermosa todos los corazones que quiebra" (p. 197)

Es así como algunos personajes como Doña Rosalía Álzate, El sevillano y otros demuestran la tradición en músicas españolas adaptadas a la expresión criolla que más luego se transformarán en pasillos, guabinas, fandanguillos. Será Tomas Carrasquilla quién permita la música por medio de pasajes donde las fiestas, celebraciones públicas y religiosas dejen escuchar las armonías de contradanzas, bundes, torbellinos "expresiones artísticas que componen la gama cultural que se hallaba desde la conquista en tierras americanas y que comienzan a transformarse como resultado del contacto intercultural desde la época colonial" (Restrepo, 2003, p. 28).

Carrasquilla según la autora de esta investigación representa en la Marquesa de Yolombó la interacción de expresiones artísticas diversas que componen la gama cultural que se hallaba en la región y por supuesto Colombia: sincretismo, mixtura, transculturación; 
cierra la autora con una frase de Alejandro Carpentier: “ los instrumentos de Europa, de África y de América, se habían encontrado, mezclado, concertado, en ese poderoso crisol de civilizaciones, encrucijada planetaria, lugar de sincretismos, transculturaciones, simbiosis de músicas aún muy primigenias o ya muy elaboradas, que era el nuevo mundo" ( p.29); así lo expresa el siguiente fragmento:

\section{Fragmento 2:}

Durante siete días, nadie asomaba por esos palacios encantados de la luna de miel; pero, a la octava noche, despertaban a los recién casados con la serenata ritual. Música y letra la componían todos los entendidos en estas artes chuscas, que no eran pocas, en este pueblo de bromistas desocupados. Tales serenatas, tenían que ser según lo tradicional (p.74).

Carrasquilla permite ubicar en la historia una paradoja que subyace a la dominación esclavista, los dominados no sólo se resistieron a los procesos de aculturación total, sino que se adaptaron a algunas formas socioculturales impuestas (como son las serenatas) e hicieron importantes aportes a la sociedad dominante con la variedad y riqueza de sus conocimientos y sus artes.

\subsection{La Didáctica en los procesos de enseñanza y aprendizaje}

La didáctica es una disciplina teórica que se ocupa de estudiar la acción pedagógica, es decir, las prácticas de la enseñanza, y que tiene como misión "describirlas, explicarlas, fundamentarlas y enunciar normas, para la mejor resolución de los problemas dentro del aula" (Hernández, 2004, p.20). Al fijar una postura epistemológica sobre la didáctica y su implementación dentro del acto educativo, puede decirse que: “es el conocimiento a través 
del cual el saber pedagógico ha pensado en la enseñanza para hacerla el objeto central de sus elaboraciones" (p.23).

Así pues, la didáctica, permite el adecuado proceso de enseñanza y aprendizaje dentro de distintos campos y niveles de conocimiento, por lo cual su implementación es un factor determinante al momento de generarse el acto de enseñar y aprender dentro y fuera del aula o en diferentes escenarios educativos, razón por la cual, se comprende que la didáctica es: "una disciplina que estudia diversos componentes, humanos y materiales que intervienen en el proceso de enseñanza y aprendizaje” ( Gómez, 2010, p.31).

Por consiguiente, la didáctica es una disciplina práctica, que se incluye en el campo más amplio de las ciencias de la educación ${ }^{15}$. En ese sentido, el objeto de estudio de la didáctica son los sistemas de enseñanza-aprendizaje, en tanto que en ellos se aborden fenómenos materiales y naturales. No obstante, el carácter práctico de esta disciplina hace que su finalidad "no se limite a la descripción - explicación de dichos sistemas, sino que abarque también aspectos relacionados con la valoración y transformación de los mismos atendiendo a criterios de calidad y de coherencia con los objetivos generales de la educación Porlán, citado por Vallejo, 2015, p. 9). Teniendo esto en cuenta, la finalidad de la didáctica presenta dos dimensiones complementarias: "describir y analizar los problemas más significativos del proceso de aprendizaje de las ciencias y elaborar y experimentar modelos que, a la luz de los problemas detectados, ofrezcan alternativas prácticas fundamentadas y coherentes en el aula" (Vallejo, 2015, p. 6).

\footnotetext{
15 Aun cuando su origen está más vinculado a las ciencias experimentales, actualmente, después de un amplio proceso de reflexión y reelaboración epistemológica y psicológica, está plenamente integrada en el conjunto de disciplinas que se interesan por los problemas educativos (Vallejo, 2015).
} 
La implementación de la didáctica dentro del aula, se constituye en una oportunidad por contribuir "al desarrollo del estudiante en sus capacidades motrices, corporales, física e incluso actitudinales, con las que se permite también la mejora y avance en los demás campos de conocimiento" (p.35). Sin embargo, la didáctica en la actualidad "exige nuevos métodos y técnicas de enseñanza, coherentes con la realidad educativa y con la visión nueva del proceso formativo" (p.42), esto trae como consecuencia que el docente busque mejorar sus prácticas y recursos con los cuales se genere un adecuado espacio de aprendizaje en el aula.

La Didáctica como una reflexión permanente del quehacer docente y su materialización en los procesos de enseñanza y aprendizaje, es fundamental en la construcción de conocimiento. De hecho, "se observan relaciones de conocimiento establecidas entre el sujeto que aprende y el contenido de enseñanza representados en conocimientos socialmente reconocidos y seleccionados" (Buchelli, 2009, p. 17).

Para que el conocimiento erudito se transforme en conocimiento a enseñar y finalmente se traduzca en conocimiento enseñado, aparece la "la transposición didáctica que transforma una disciplina en objeto de conocimiento, y por tanto, los diferentes saberes disciplinares se pueden convertir en saberes a ser enseñados y aprendidos" (p.18). En términos de Chevallard, la transposición didáctica se desarrolla como:

Un contenido de saber que ha sido designado como saber a enseñar, sufre a partir de entonces un conjunto de transformaciones adaptativas que lo harán apto para ocupar un lugar entre los objetos de enseñanza. El "trabajo" que transforma un objeto de saber en uno de enseñanza, es denominado la transposición didáctica (Buchelli, 2009, p.23). Desde esta consideración, la transposición didáctica requiere del maestro, la enseñanza y el formar para lograr que el conocimiento llega adecuadamente al estudiante en el aula de clases, como bien aparece en la siguiente gráfica: 


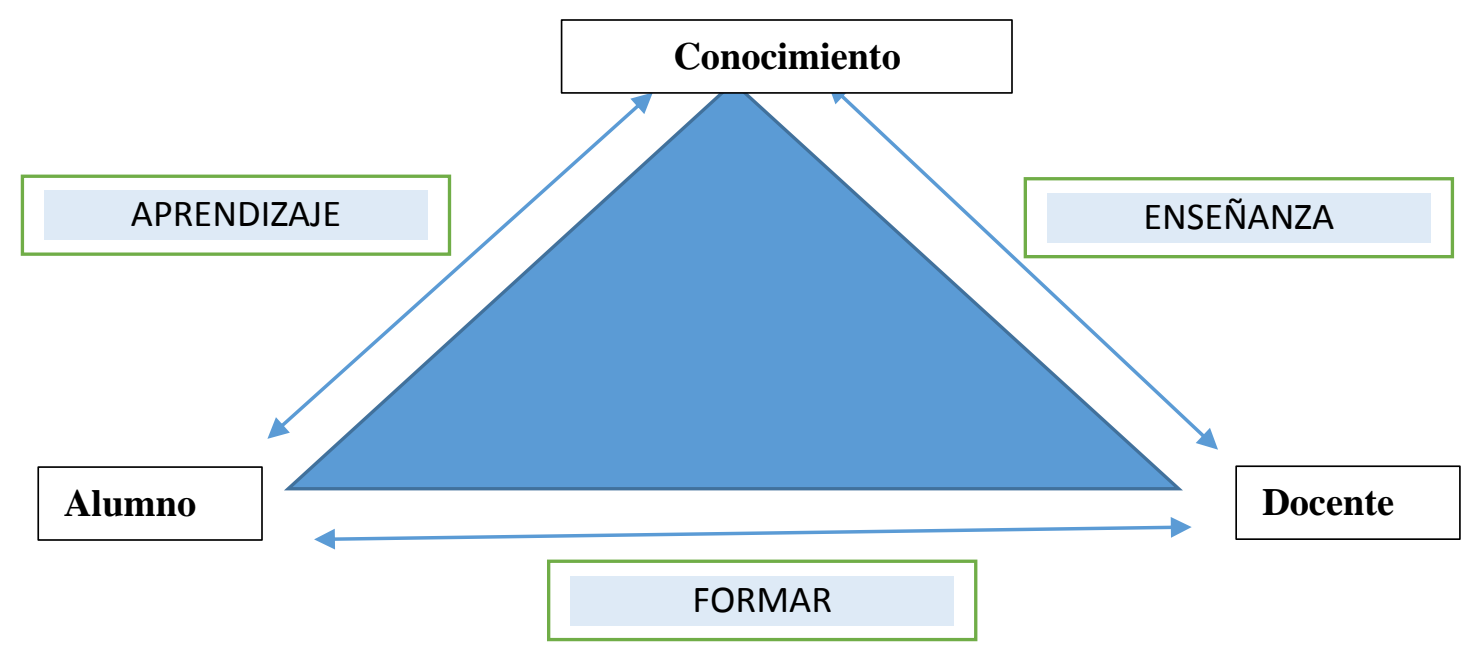

Figura 1: Transposición didáctica

Fuente: Pimienta (1994).

En conclusión, el "trabajo" que transforma un objeto de saber enseñar en un objeto de enseñanza", es lo que se denomina como "transposición didáctica, específicamente, entre el objeto de saber y el objeto de enseñanza, se incluye el concepto objeto a enseñar y se evidencia cuando el objeto de saber se incorpora en el currículo de estudio" (p.32). Esto conlleva a comprender que en el caso de la didáctica de la lectura literaria de la novela histórica es fundamental que el docente promueva procesos de enseñanza, con base en la consolidación del conocimiento que se da a partir de la interacción entre el docente y el estudiante, desde la comprensión, análisis e interpretación de las novelas históricas en la clase de literatura.

\subsubsection{Didáctica de la literatura}

La literatura se concibe como la representación de las culturas y la suscitación de lo estético; "la literatura como lugar de convergencia de las manifestaciones humanas, de la ciencia y de las otras artes y la literatura como ámbito testimonial en el que se identifican tendencias, 
rasgos de la oralidad, momentos históricos, autores y obras" (MEN, citado por Vallejo, 2015, p. 20). De esta manera, la enseñanza de la literatura se ofrece en vista de:

La creación literaria, el abarcamiento y análisis de la obra, la construcción de significado, entre otros; todo ello expresado a través de 3 ejes que son: - la literatura como representación de las culturas y suscitación de lo estético - la literatura como lugar de convergencia de las manifestaciones humanas, de la ciencia y de las otras artes. - la literatura como ámbito testimonial en el que se identifican tendencias, rasgos de la oralidad, momentos históricos, autores y obras (p.23).

En ese sentido, la literatura como espacio de comprensión de la oralidad, de los momentos históricos en las obras de los autores busca reflejar a través de la palabra las distintas manifestaciones humanas que convergen en la narración de la obra. Por tanto, el estudio literario responde a tres paradigmas, que son fundamentales tener en cuenta a la hora de compartir la literatura en el aula, como son: estética; historiografía y sociología y la semiótica. El nivel estético responde a la creación literaria, la construcción de diversos textos respondiendo a la composición de piezas, poemas, cuentos, fragmentos, etc. el segundo "es la forma clásica en que se aprende la literatura, que corresponde a su enseñanza lineal e histórica, donde se reconoce los autores, los movimientos y las obras específicas” (p.29) y el tercero, tiene que ver con el análisis de las obras.

En cuanto a los problemas que se pueden presentar en los tres aspectos mencionados, radica en que puede darse una educación literaria sin el contenido de las obras mismas, o donde no se especifique con claridad los conceptos a usar, por otra parte, se resalta la importancia de tener en claro que no existe un método único que responda a todos los contextos y grados de aprendizaje para enseñar literatura en el aula, a este respecto Vallejo ( 2015) recomienda aplicar siete enfoques en la didáctica de la literatura en el aula: 
En primer lugar, está el enfoque comunicativo en el que la literatura se concibe como un discurso con el que se pueden desarrollar competencias en el estudiante. En segundo lugar, “están las propuestas didácticas cuyo propósito es el hecho literario, en este enfoque el propósito es traducir las experiencias propias de la crítica y la teoría literaria a los problemas de la didáctica" (p.31). La reflexión hermenéutica aquí es muy importante pues busca la relación entre la significación que vehiculan las obras literarias y las competencias particulares que desarrollan los estudiantes

En tercer lugar, se encuentran las didácticas de perspectiva literaria centrada en el lector en el que se enfatiza la recepción del texto y en el goce estético, llamada también didáctica de la lectura. En cuarto lugar, "se encuentran las didácticas de perspectiva pedagógica centrada en el alumno (y no en los contenidos o en el profesor) haciendo especial hincapié en los procesos de aprendizaje, la actividad cognitiva, comunicativa y de valoración estética" (p.31). En quinto lugar, se encuentran las didácticas de perspectiva psicológica centrada en los procesos cognitivos, de carácter constructivistas. En sexto lugar, "se encuentran las didácticas de perspectiva audiovisual y el diálogo cultural” (p.32), y, en séptimo lugar, la perspectiva de la didáctica de la escritura, Se trata aquí de "promover y estudiar la expresión o producción del discurso literario" (p.33).

En resumen, una didáctica de la literatura busca que el estudiante desarrolle competencias comunicativas, a su vez que éste tenga la capacidad de generar una lectura crítica de las obras literarias, y por consiguiente, esto conlleva a que el estudiante desarrolle un proceso de aprendizaje constructivista, a partir del cual logre relacionar lo que aprende en el aula, y lo contextualice con la realidad; de ahí lo fundamental de generar procesos de enseñanza y aprendizaje de la lectura literaria de las novelas históricas que generen en los 
estudiantes una comprensión y una crítica contextualizada de lo que propone el autor en la obra.

\subsubsection{Didáctica de la lectura literaria}

La educación literaria se propone esencialmente que un lector sepa cómo se ha de construir el significado de lo que lee según las instrucciones ofrecidas por el texto. Estas instrucciones “deberán guiarle también en el descubrimiento de la plusvalía de significado que la construcción literaria añade a las reglas de la lengua natural” (Bertoni, citado Colomer, 2015, p.3). Para adoptar esta perspectiva, los procesos de enseñanza y aprendizaje de la lectura literaria requieren de comprender "el nexo entre las intenciones del autor, la cognición del lector y las propiedades del texto durante el proceso de interpretación” (p.4). Para este propósito, el significado está entre el autor y el lector, dado que:

El mensaje no es transmitido desde el autor al lector sino que es construido como una especie de puente ideológico, edificado en el proceso de su interacción. En virtud del pacto que el lector asume al abrir un libro, ha de saber suspender las condiciones de "verdad" referidas al mundo real y aceptar que el discurso de un relato, por ejemplo, es una organización convencional que se propone como verdadera (p.5).

Así pues, a partir de los signos ofrecidos por el texto, el lector ha de saber distinguir entre el narrador y el autor y, a la vez, "ha de saber distinguirse a sí mismo como receptor real respecto al papel de los receptores que actúan dentro del texto" ( p.6). Desde el inicio del discurso deberá aceptar el juego previsto por el autor y aprender a seguir los elementos meta discursivos que le dan instrucciones sobre cómo ha de interpretar la obra. De esta manera, el lector ha de saber entender las voces orquestadas en el interior de la obra y "vivir" entre ellas 
Así, por ejemplo, la lectura literaria de obras históricas pueden ayudar a crear serias expectativas sobre "cómo es el mundo y cómo se habla de él sin necesidad de evaluar y contrastar su realidad" (p.7). La relación entre la experiencia obtenida directamente del mundo primario y la otorgada por la mediación literaria se hace más compleja a medida que los estudiantes enriquecen su experiencia vital y de lectura. De esta manera, dentro de la didáctica de la lectura literaria, Colomer (2015), expone desarrollar líneas de trabajo por proyectos, a través de los cuales se comprenda e interprete adecuadamente la didáctica de la lectura literaria, a este respecto, aparecen las siguientes ventajas:

Primero, integra los aspectos y disfrute del texto con las ayudas a su comprensión y con el aprendizaje de aspectos literarios concretos. Segundo, se interrelaciona las actividades de lectura y escritura; y tercero, "favorecen la asimilación de los aprendizajes, los estudiantes recuerdan mejor la lectura de determinados textos su se halla incluida en el recuerdo global de un tipo de actividad extensa y con sentido propio" (Colomer, 2015, p. 19). En ese sentido, las actividades de lectura literaria en el aula de clase contribuyen a que los estudiantes asimilen realmente los aprendizajes, y logren recordar y apropiarse del texto leído.

Otra línea de trabajo corresponde a la didáctica de la lectura literaria desde la intertextualidad, dado que esto potencializa el conocimiento "de las interrelaciones producidas entre las literaturas que resultan familiares a los estudiantes "(p.23), además de esto, se logran conexiones sucesivas de las obras, tópicos y modos literarios que configuran el sentido comprensivo del texto; se trata entonces de cohesionar la obra histórica con los modos literarios que la configuran y el sentido comprensivo de la obra, desde una lectura contextualizada del texto. 


\subsubsection{Didáctica crítica de la lectura literaria}

La didáctica crítica concibe la acción didáctica como la vía para la formación de estructuras mentales, la organización de conocimientos fragmentados y reconstrucción crítica de los problemas cotidianos en "la esfera comunitaria, regional, nacional, continental y mundial; por ello, este enfoque exige un convencimiento crítico previo del educador, un profesorinvestigador reflexivo, examinador, comprometido con la situación educativa, transformador del aula, de la institución escolar y de su entorno" ( Rodríguez, 2007, p. 241). En esa perspectiva, la metodología de este tipo de docente debe llevarlo a dar la palabra al alumno, puesto que la multiplicidad de voces genera una "lectura y una escritura distintas; así mismo, valora la evaluación que permita al estudiante participar, que sea vista como un proceso no como una acción terminada y definitiva" (p.242).

Así mismo, los autores Díaz-Barriga y Hernández (2002) también señalan que los aprendizajes deben ser construidos por los estudiantes en contextos determinados partiendo de sus experiencias y conocimientos previos; por ello señala que "la comprensión de textos es una actividad constructiva compleja de carácter estratégico, que implica la interacción entre las características del lector y del texto, dentro de un contexto determinado" (p. 275). Los escritores consideran que la lectura es una actividad de construcción de significados sugeridos por el texto haciendo uso de habilidades cognitivas y de estrategias para abordar el discurso escrito.

Así pues, el tipo de lectura que se requiere para ello es la lectura crítica que constituye la competencia que se desea lograr en el área de Literatura y por tanto, el estudiante debe desarrollar la habilidad para expresar de "manera crítica y significativa -indistintamente del 
tema en estudio- sus ideas, pensamientos, cuestionamientos y emociones" ( p.243); de igual modo, es importante también desarrollar en los estudiantes la auto-crítica como una forma de desarrollar consciencia ante la lectura literaria de obras históricas.

Para desarrollar una adecuada lectura crítica en el aula, el autor Burón (2002) propone la meta lectura como "el conjunto de conocimientos que tenemos sobre la lectura y sobre los procesos mentales que debemos realizar para leer" (Burón, citado por Gutiérrez, 2007, p. 250).

Par lograr el desarrollo de habilidades de lectura, los textos deben ser revisados atendiendo a su macro y microestructuras semánticas; la primera atañe al sentido global del texto pues cada vez que el lector lee, "construye una representación mental de su comprensión del texto" (p. 245) que luego contrasta con los conocimientos que posee sobre el tema, las convenciones, los valores y las actitudes que le son propias (supuesto pragmático y situacional). La segunda se asocia al conjunto de proposiciones que integran el texto, es decir, "el conjunto de micro proposiciones que establecen la coherencia local o parcial del mismo" (Gutiérrez, 2007, p. 267).

En resumen, una didáctica crítica de la lectura literaria de las obras históricas debe promover en la adecuada revisión de los personajes, los temas de la obra de manera reflexiva, los capítulos específicos con las respectivas inferencias de lo leído, de manera que esto contribuya a que el estudiante desarrolle un proceso de aprendizaje consciente, interpretativo y crítico de las obras históricas, para lo cual se requiere establecer algunas estrategias de lectura literaria de la novela histórica como se explica en el siguiente apartado. 


\subsubsection{Estrategias de lectura literaria en la novela histórica}

En lo que respecta a las estrategias de la lectura literaria en la novela histórica, es indispensable en términos de Colomer (1995), exponer algunos aspectos que son necesarios en la lectura de textos históricos como son:

Primero, construir el significado de manera compartida; esto significa que "a pesar de que la lectura literaria se caracteriza por apelar radicalmente a la respuesta subjetiva del lector, la interacción entre la lectura individual y el comentario público la enriquece y modifica si se consigue un contexto educativo de construcción compartida" (Colomer, 1995, p.2), en el cual se logra comprender la intencionalidad de la obra histórica, a partir de los diversos significados que se comparten en la discusión de la obra. De hecho, la discusión entre los compañeros, la información suministrada por el docente y "las referencias coincidentes o contrastadas, explícitas o implícitas- entre las obras leídas permiten que los estudiantes vayan construyendo los modelos del funcionamiento literario" (p.4).

Segundo, ayudar a progresar en la capacidad de hacer interpretaciones más complejas; éste es un punto especialmente delicado ya que "requiere tanto prever el itinerario de este progreso cómo hacer que los alumnos lo construyan personalmente" (p.6). Y, a menudo, el poder de hacer interpretaciones a través de las pistas textuales no se desarrolla de la mejor manera posible en una escuela que educa en la búsqueda de un solo significado, muy próximo al significado literal, en ese sentido, el ejercicio interpretativo de la obra histórica es una estrategia fundamental en la lectura literaria, puesto que permite al estudiante comprender el texto, contextualizarlo, analizar la intencionalidad del autor, y por consiguiente, elaborar inferencias sobre lo que se evidenció en la lectura de la novela histórica.

Tercero, prever actividades que favorezcan todas las operaciones implicadas en la lectura. "En los últimos años han llegado a la escuela múltiples propuestas de actividades 
sobre los mecanismos de la lectura de textos, desde cómo relacionar los conocimientos previos de los lectores" (p.18), hasta actividades de inferencias e integración de la información, de predicción, de control de la propia comprensión. Dentro de las actividades que el docente puede realizar en la lectura literaria de la novela histórica aparecen los talleres grupales, ejercicios didácticos a partir del juego, en el cual los estudiantes realizan "desde la lúdica acciones comprensivas e interpretativas de momentos históricos de las obras, sus personajes, y otros recursos de la novela histórica que se enriquecen con la lúdica" (Solé, citado por Colomer, 1995, p.13).

Y, finalmente, se requiere interrelacionar las actividades tanto de recepción como de expresión literarias, y tanto en su forma oral como escrita. A pesar de que nos hemos situado en la perspectiva de la lectura, es evidente que todas estas actividades se refuerzan mutuamente al servicio del progreso de la competencia literaria. También "se deberán interrelacionar las vías por las que los alumnos adquieren esta competencia, haciendo especial atención a los referentes audiovisuales, tan presentes en nuestra sociedad" (Armellini, citado por Colomer, 1995, p. 3). En ese aspecto, se pretende que el docente recurra a estrategias de las TIC para incorporarlas en los procesos de enseñanza de la lectura literaria de la novela histórica, desde esta perspectiva, se busca a través de los medios digitales y audiovisuales promover un aprendizaje de la lectura y la escritura dinámicos, es decir, en el cual los estudiantes desarrollen sus competencias cognitivas y habilidades sociales en la comprensión de las obras históricas. 


\subsubsection{Secuencia didáctica para los procesos formativos de los docentes}

La importancia de los procesos de enseñanza y aprendizaje en el aula de clase radican en la capacidad del docente de articular lo curricular con lo didáctico. Al respecto, es necesario que el docente identifique qué aspectos de su práctica pedagógica “deben alterarse y cómo; luego, en qué dimensiones hay que trabajar a nivel de centro o qué haya que reclamar de la política educativa" (Bolívar, 2011, p.4). Para este propósito, "se requiere de la innovación en la didáctica de la lectura literaria de la novela histórica; ya que si una innovación (curricular, organizativa o profesional)" (p.6) no incide en la calidad de aprendizaje de los alumnos, difícilmente se logre trabajar los procesos de lectura literaria de las obras históricas.

En este contexto, la didáctica es "una condición requerida por el maestro si es de su interés desarrollar procesos de aprendizaje significativo, debe responder al reto simbólico del ser y el hacer cultural y apuntarle a la nueva dinámica educativa” (p.12). La didáctica cumple una función fundamental pues permite que los estudiantes integren mejor dentro de su estructura mental la coherencia y conexión de los conocimientos que potencian el aprendizaje a largo plazo; a partir de los recursos diversificados que estimulan el proceso de aprendizaje de la lectura literaria de obras históricas.

Por eso, uno de los retos en la actualidad es que el estudiante potencie su capacidad interpretativa de la lectura literaria, y esto se lo permite el desarrollo del pensamiento simbólico, por dicha razón hablar de unas recetas claves para la enseñanza "no es algo que se pueda hacer sin atropellar las diversas formas de la educación, empero es indudable la importancia que adquiere la didáctica para que en la actualidad podamos hablar de una real implementación del aprendizaje” (p.19). Pensar en prácticas pedagógicas implica diseñar 
estrategias didácticas orientadas a que los educandos no solo reciban información, "sino que fundamentalmente sean capaces de modificarla y aplicarla, de compartir las inquietudes actuales en torno al conocimiento" ( Vallejo, 2015, p. 32).

En esta dinámica, aparece la secuencia didáctica como una unidad de enseñanza en los procesos de enseñanza y aprendizaje, la cual posee las siguientes características:

1. Se formula como un proyecto de trabajo que tiene como objetivo la producción de un texto, y que se desarrolla durante un determinado período de tiempo más o menos largo, según convenga. 2. La producción del texto, base del proyecto, forma parte de una situación discursiva que le dará sentido, partiendo de la base que texto y contex to son inseparables. 3. Se plantea unos objetivos de enseñanza/aprendizaje delimitados que han de ser explícitos para los alumnos. Estos objetivos se convertirán en los criterios de evaluación. La articulación del trabajo de producción global y de unos objetivos puntuales se fundamenta en el concepto de «foco» de la actividad. Los alumnos llevan a cabo la actividad global a partir de los conocimientos que ya tienen y la atención didáctica preferente se orienta hacia los nuevos objetivos de aprendizaje (Camps, 2012, p.4).

Por tanto, la secuencia didáctica inicia con un proyecto de trabajo sobre una obra histórica, con unos objetivos claros a desarrollar, los cuales se llevarán a cabo a partir de las actividades de la secuencia, para generar nuevos aprendizajes de la lectura literaria de la novela histórica; es decir, "generar procesos centrados en el aprendizaje, trabajar por situaciones reales, reconocer la existencia de diversos procesos intelectuales y de la variada complejidad de los mismos” (D’Hainaut, citado por Barriga, 2013, p. 3).

La construcción de una secuencia tiene como punto de partida una serie de aspectos formales que emanan del plan de estudios, pero particularmente del programa en el que 
inscribe. Puede ser materia, asignatura, módulo, unidad de aprendizaje o la denominación que el currículo establezca para el trabajo docente. Esto conlleva la necesidad de "construir secuencias didácticas a partir de algún elemento/problema de la realidad, cuestión que ayudará al docente a crear un interrogante, un enigma que dé sentido al acto de aprender" (Barriga, 2013, p.5).

La estructura de la secuencia se integra con dos elementos que se realizan de manera paralela: "la secuencia de las actividades para el aprendizaje y la evaluación para el aprendizaje inscrita en esas mismas actividades, las que es conveniente que encuentren sentido a través de un problema eje o un proyecto" ( p.6), que permite organizar la estructura de secuencias. El inicio de la secuencia es necesario tener claridad de las actividades de evaluación para el aprendizaje, incluso es importante lograr una visión integral de las evidencias de aprendizaje, para así lograr una articulación entre contenidos y algunos elementos de la realidad que viven los alumnos en la comprensión de la lectura literaria de las obras históricas.

Por su parte, la línea de secuencias didácticas está integrada por tres tipos de actividades: apertura, desarrollo y cierre. En la conformación de esta propuesta de actividades subyace simultáneamente una perspectiva de evaluación formativa, la que permite retroalimentar el proceso mediante la observación de los avances, retos y dificultades que presentan los alumnos en su trabajo, como de evaluación sumativa, la que ofrece evidencias de aprendizaje.

En un primer momento, aparecen las actividades de apertura; en las cuales el docente "logra pedir que trabajen con un problema de la realidad, o bien, abrir una discusión en pequeños grupos sobre una pregunta que parta de interrogantes significativas para los 
alumnos" (p.12), éstos reaccionarán trayendo a su pensamiento diversas informaciones que ya poseen, sea por su formación escolar previa, sea por su experiencia cotidiana.

En un segundo momento, se encuentran las actividades de desarrollo; éstas tienen la finalidad de que el estudiante interaccione con una nueva información; dado que el estudiante cuenta con una serie de "conocimientos previos — en mayor o menor medida adecuados y/o suficientes - sobre un tema, a partir de los cuáles le puede dar sentido y significado a una información" (p.15). Para significar esa información se requiere lograr colocar en interacción: la información previa, la nueva información y hasta donde sea posible un referente contextual que ayude a darle sentido actual.

Y, finalmente, las actividades de cierre; las cuales se realizan con la finalidad de lograr una integración del conjunto de tareas realizadas, y permiten realizar una síntesis del proceso y del aprendizaje. A través de ellas se busca que el "estudiante logre reelaborar la estructura conceptual que tenía al principio de la secuencia, reorganizando su estructura de pensamiento a partir de las interacciones que ha generado con las nuevas interrogantes y la información a la que tuvo acceso" (p.15). Estas actividades de síntesis pueden consistir en reconstruir información a partir de determinadas preguntas, realizar ejercicios que impliquen emplear información en la resolución de situaciones específicas (entre más inéditas y desafiantes mejor). Las actividades de cierre, posibilitan una perspectiva de evaluación para el docente y el estudiante, tanto en el sentido formativo, como sumativo; es decir, que las actividades propuestas en la secuencia pueden generar múltiple información tanto sobre el proceso de aprender de los alumnos, como para la obtención de evidencias de aprendizaje. 


\subsubsection{La secuencia didáctica de la Marquesa de Yolombó}

La parte final de este trabajo se enfoca en el diseño de una propuesta didáctica que facilite a docentes y estudiantes una lectura literaria de la obra la Marquesa de Yolombó, y que por tanto, se integre al plan lector del curso de octavo grado.

La estrategia por utilizar se basa en un modelo de análisis que integre la visión del texto narrativo desde los ámbitos de lo histórico, lo literario y lo pedagógico dado las temáticas que se entrecruzan en el texto de Carrasquilla. Esto supone, que al finalizar la lectura de esta novela, el estudiante pueda comprender, la dimensión de los hechos históricos que allí se mencionan en la obra; la forma en que el autor los aborda, el hecho educativo que hay inmerso en el relato y el valor desde lo estético de la misma obra. También, se revisará cómo los temas reivindicación de lo femenino, costumbrismo, lenguaje y sincretismo cultural, los cuales son fundamentales para la creación narrativa de la lectura literaria de esta obra.

Esta propuesta didáctica se convierte en la exposición de forma sistemática y fundada que conlleva una serie de objetivos, contenidos, metodología, actividades y aspectos organizativos que se proponen desde la asignatura de Lengua Castellana, y en el Ciclo IV, para el estudio y análisis de una obra literaria como un mecanismo de EnseñanzaAprendizaje por desarrollarse en el aula de clase en las instituciones Tabora I.E.D ubicado en la Localidad $10^{\circ}$ Engativá y Fabio Lozano Simonelli de la Localidad $5^{\circ}$ Usme.

Para ello, se debe anclar la novela al plan lector de la institución educativa. Una vez allí el maestro determina y planifica qué aspectos le son relevantes para el estudio de la obra: la historia, lo costumbrista, el lenguaje, etc. Acto seguido, se da paso a contextualizar la novela con respecto al tiempo actual en cuanto a equidad, género, folclor y de esta forma hacer interdisciplinaridad en su abordaje narrativo. En cuanto a la estructuración de las 
La Marquesa de Yolombó: Una propuesta didáctica de la Lectura Literaria. 90

sesiones de trabajo, es factible acudir a las secuencias didácticas como modelos de trasposición de esta u otras novelas históricas. 
Tabla: Tema base: La novela histórica

\begin{tabular}{|c|c|}
\hline $\begin{array}{l}\text { SECUENCIA DE APRENDIZAJE } \\
\text { GRADO: } 8^{\circ}\end{array}$ & DURACIÓN: 8 sesiones ( 45 minutos cada una) \\
\hline ASIGNATURA: Lengua Castellana & $\begin{array}{l}\text { CONTENIDOS: Novela histórica, "La marquesa de } \\
\text { Yolombó", descripción, reseña y biografía. }\end{array}$ \\
\hline $\begin{array}{l}\text { TEMA: } \\
\text { Géneros Literarios } \\
\text { - Género Narrativo: Novela histórica. }\end{array}$ & $\begin{array}{l}\text { OBJETIVO: Establecer un modelo de análisis para la } \\
\text { novela histórica "La Marquesa de Yolombó". }\end{array}$ \\
\hline PROFESORA: Luisa Fernanda Nieto Bustos & 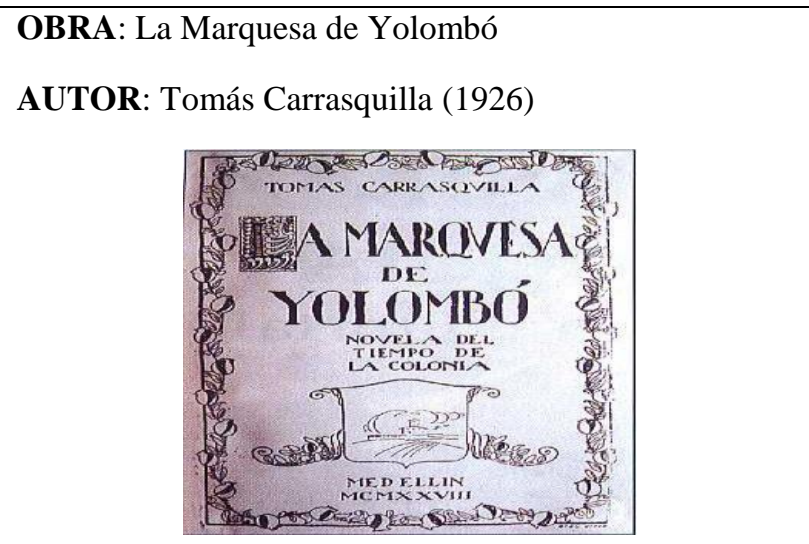 \\
\hline $\begin{array}{l}\text { SECUENCIA DE APRENDIZAJE } 1 . \\
\text { ACTIVIDADES DE INICIACIÓN O } \\
\text { APERTURA } \\
\text { Como actividad de apertura, partiremos de los } \\
\text { conocimientos previos de los estudiantes, que } \\
\text { permitan una introducción a la literatura } \\
\text { colombiana. Como eje del tema se propone "La } \\
\text { Marquesa de Yolombó" de Tomás Carrasquilla. } \\
\text { Una primera actividad es revisar las clases de } \\
\text { descripción, a partir de dos fragmentos. }\end{array}$ & $\begin{array}{l}\text { "La religión católica, alma mater de la Colonia, tenía allí } \\
\text { emporio tan pujante, que, a más de la fundadora, había } \\
\text { levantado dos iglesias. Los fieles cumplían estrictamente } \\
\text { los cinco mandamientos y todo indio o liberto que se } \\
\text { hiciese el remiso para asistir al "incruento sacrificio" lo } \\
\text { arreaban a latigazos hasta la propia puerta de la iglesia. } \\
\text { Algo semejante le acontecía a quien se obstinaba en no } \\
\text { pagar el diezmo"(Pág. 74) }\end{array}$ \\
\hline $\begin{array}{l}\text { FRAGMENTO 1: Definir en conjunto La } \\
\text { Colonia, La minería, La Esclavitud y la región } \\
\text { Oriental de Antioquia. Traer mapa (actividad } \\
\text { complementaria). Se lee fragmento } 1 \text {, en grupos } \\
\text { dibujarán o contarán la primera impresión que } \\
\text { les genera el fragmento leído y posteriormente se } \\
\text { compartirá en plenaria. Se comenzará la }\end{array}$ & $\begin{array}{l}\text { FRAGMENTO } 2 \\
\text { "Por la noche hay licor libre, de seis a siete. A los que } \\
\text { no van a l estanco se lo llevan a donde estén; hay refresco } \\
\text { bailable en casa de la anfitriona. Pone la contradanza, } \\
\text { aprendida en Antioquia; luego, acompañada de Narcisa, }\end{array}$ \\
\hline
\end{tabular}


construcción de un espacio literario visible dentro o fuera del aula.

Fragmento 2: Se solicita a los estudiantes observar las pinturas alusivas a la obra y con base en el texto comentar que suscita en ellos esas imágenes.

\section{RELACIONES Y ASOCIACIONES:} Indagaremos en conjunto sobre las impresiones que tienen los estudiantes sobre los dos fragmentos e intentaremos darle un hilo conductor. ¿Qué relación pueden tener estas dos imágenes? ¿Podemos caracterizar a los habitantes de Yolombó?

\section{ACTIVIDADES DE DESARROLLO}

GÉNERO NARRATIVO: Recordar elementos de la cultura afroamericana, las danzas y otros rasgos culturales. De la misma forma consultar qué es la novela histórica, la biografía de Tomás Carrasquilla y el origen de la minería en Colombia.

Relacionar los conceptos de narrativa y novela. Para tal fin, se propondrán preguntas de provocación, se escucharán opiniones y luego en grupos se les pedirá

Consultar al respecto designando para cada pregunta un grupo.

- ¿Qué es cultura?

- ¿Qué es una región?

- ¿Recuerda cómo se da la Esclavitud en América?

- ¿Qué material se extrae de las minas en Colombia?

- ¿Cuál cree es el más utilizado y cómo?

Los estudiantes construirán una línea de tiempo en dónde, por medio de recortes, impresiones o dibujos, hagan un recorrido por los sucesos asociados a la época de la Colonia en América. saca las tonadillas y los bundes, los arpegios y panderetos, que se tenían atan guardados. La beldad africana, habituada a estas exhibiciones artísticas, se muestra, si muy en ello, muy en su puesto de negra y de esclava voluntaria. No sabe la hermosa todos los corazones que quiebra" (Pág. 197)

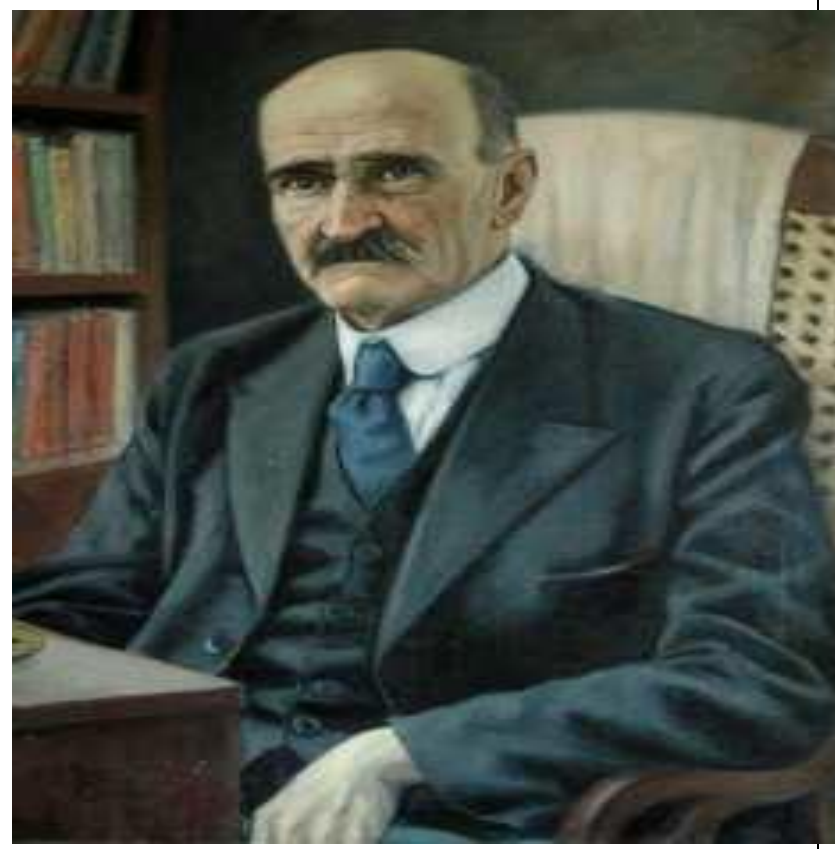




\begin{tabular}{|c|c|}
\hline $\begin{array}{l}\text { Después de leer los fragmentos } 1 \text { y } 2 \text {, el objetivo } \\
\text { será identificar algunos aspectos de época, de } \\
\text { costumbres, y posibles elementos de la novela } \\
\text { histórica o costumbrista. Se exponen las pinturas } \\
\text { alusivas y otros fragmentos de la novela con el } \\
\text { fin de conformar un ambiente de aprendizaje que } \\
\text { mantenga un hilo conductor y que pueda ser } \\
\text { leído desde cualquier punto, pero que remita } \\
\text { siempre a la novela histórica. }\end{array}$ & 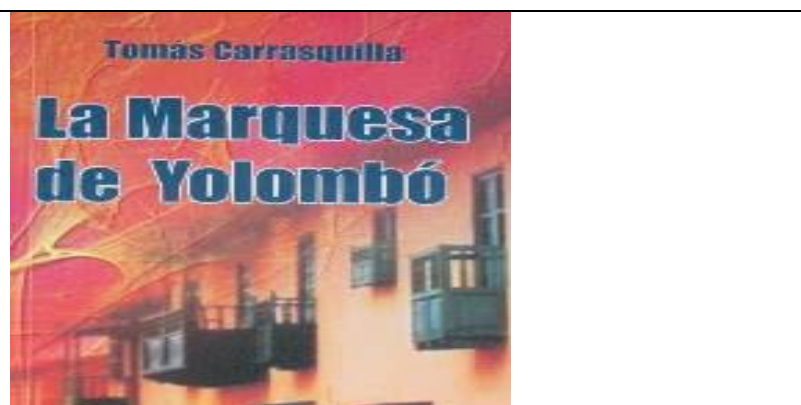 \\
\hline $\begin{array}{l}\text { Para ir delimitando el tema, otro grupo trabajará } \\
\text { otros conceptos; La justicia, el Virreinato, el } \\
\text { lenguaje de la época, etc. Luego se decide en } \\
\text { decida si realizará una cartelera, una } \\
\text { presentación en Power Point, Prezi u otros. } \\
\text { En los siguientes links encontrarás mayor } \\
\text { información sobre el contexto en que la novela } \\
\text { fue escrita: } \\
\text { file:///C:/Users/juans/Downloads/15627-52687- } \\
\underline{1-\mathrm{PB} . p d f} \\
\text { http://snuilas.snu.ac.kr/iberopdf/snuibero25030 } \\
\text { 3.pdf }\end{array}$ & \\
\hline $\begin{array}{l}\text { Como última actividad de desarrollo, leeremos } \\
\text { las sinopsis de la novela, se propone hacer una } \\
\text { reseña con los elementos básicos de la obra. } \\
\text { (Individual o manteniendo los grupos de trabajo) } \\
\text { Se leerá la iniciación, el nudo o el desenlace de } \\
\text { la novela. Posteriormente se analizan otros } \\
\text { fragmentos ejemplo de los temas tratados. Por } \\
\text { último, se propone realizar una lluvia de } \\
\text { semejanzas y diferencias entre la época de La } \\
\text { Colonia y el tiempo actual. }\end{array}$ & $\begin{array}{l}\text { SINOPSIS } \\
\text { Fruto de una investigación de muchos años, La marquesa } \\
\text { de Yolombó es ante todo una espléndida novela histórica, } \\
\text { un vasto retablo de la vida cotidiana colonial, apenas } \\
\text { comparable por su venero de información acerca de esa } \\
\text { época con las Tradiciones peruanas y con La gloria de } \\
\text { Don Ramiro. Un pueblo entero surge a la vida y se hace } \\
\text { imaginable merced a esa novela de ochenta personajes; } \\
\text { el territorio y la geografía (paisajes y climas, montes y } \\
\text { cuencas, vías y asentamientos, flora y fauna), las razas, } \\
\text { grupos y familias, la religión y la política, el lenguaje } \\
\text { coloquial --especie de "paisa-andaluz-afro-castellano"--, } \\
\text { las mentalidades; y luego las modas y los usos, los } \\
\text { alimentos y hábitos, las tradiciones y leyendas, los } \\
\text { oficios y diversiones, los cantos y bailes; las }\end{array}$ \\
\hline
\end{tabular}




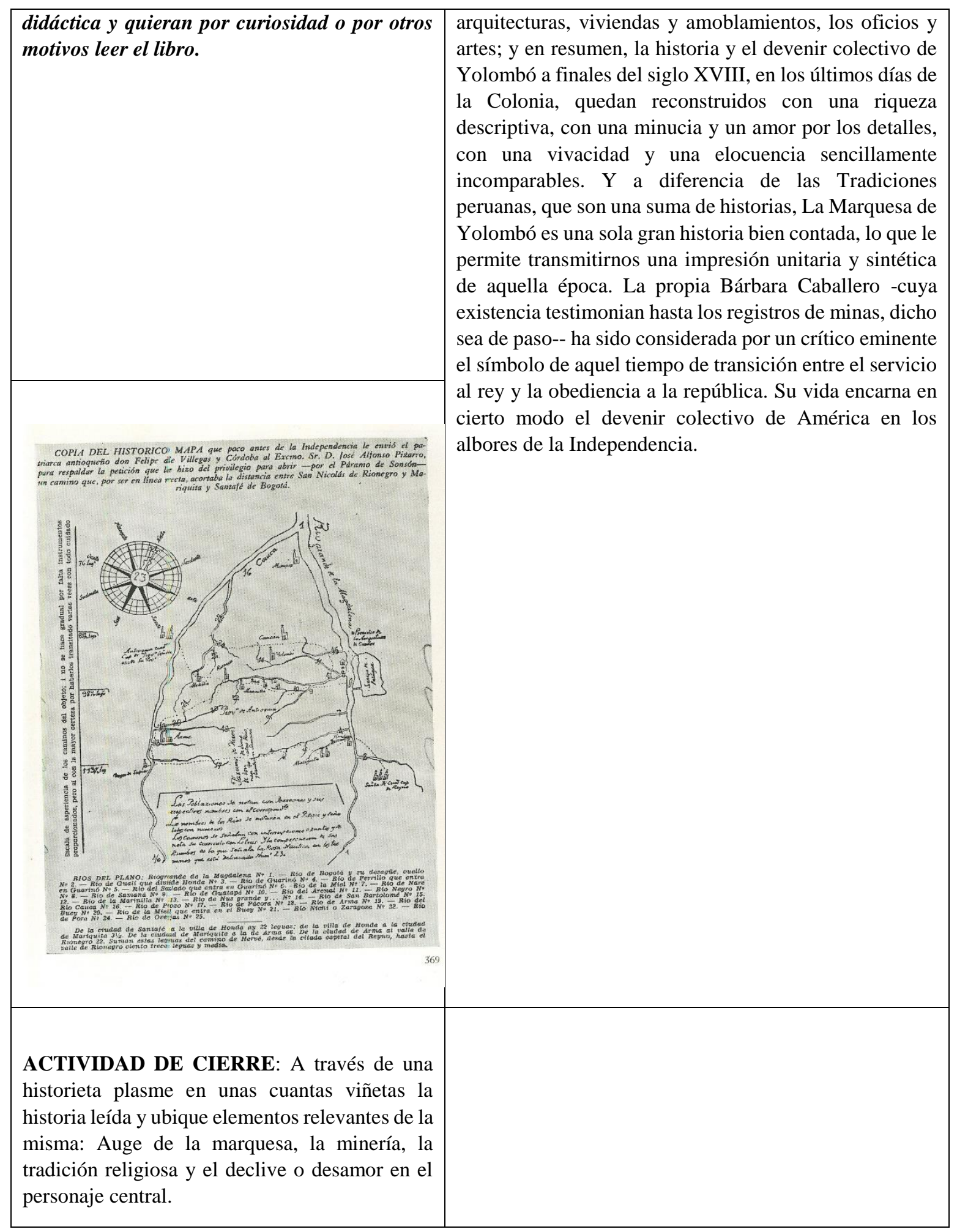


Tabla 2: Tema base: La religión

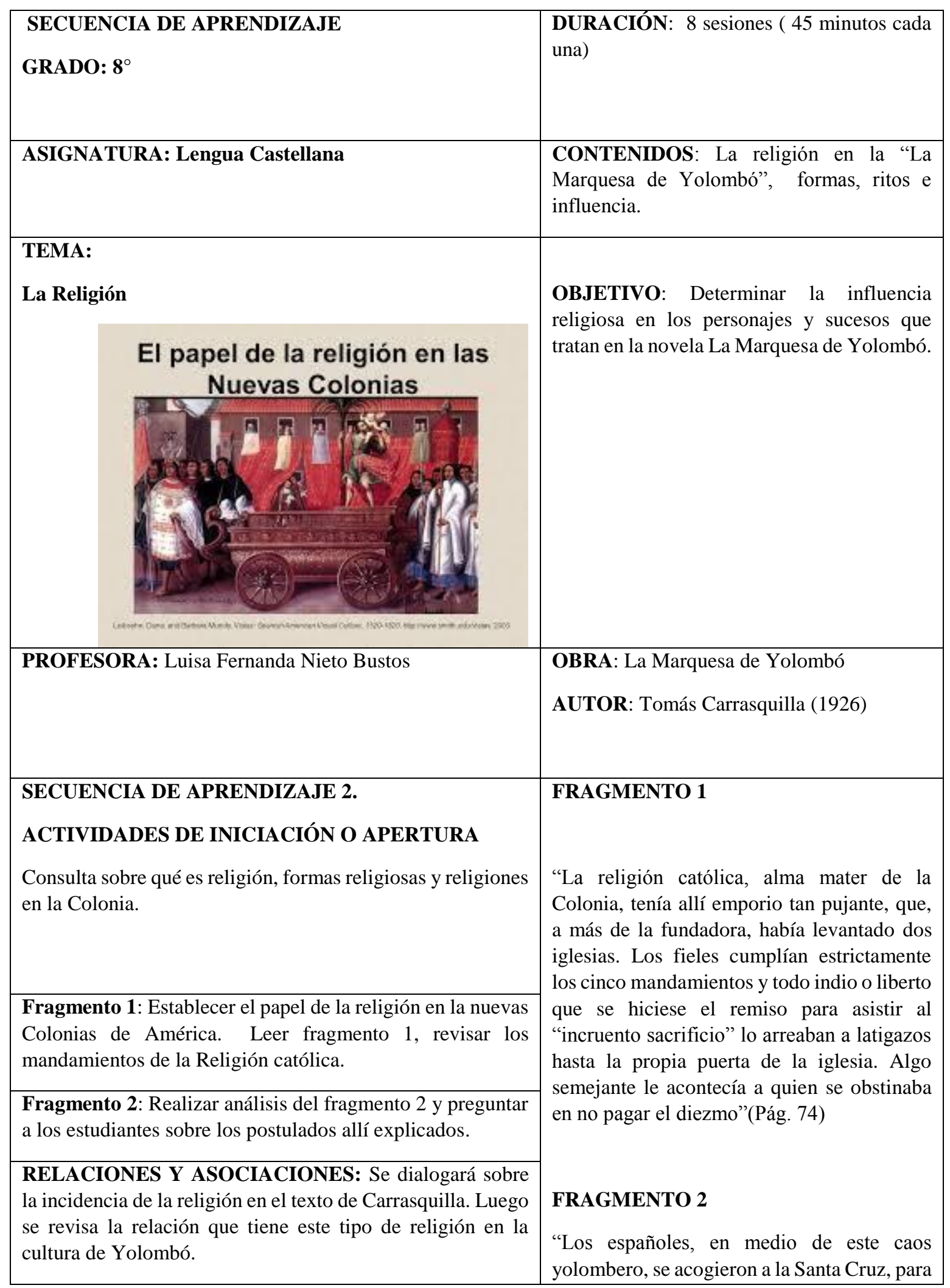




\section{ACTIVIDADES DE DESARROLLO}

LA RELIGIÓN: Revisar la forma como se hizo imperativo, para los yolomberos, adscribirse a esta religión acatólica.

Por otra parte, pedir a los estudiantes que consulten sobre el pale de las misiones en América.

En la segunda fase y luego de leer los fragmentos 1 y 2,1 tarea se centra en identificar los elementos inherentes a los ritos, costumbres y elementos religiosos que marquen a los personajes de la novela.

Actividad final: Se seleccionan otros fragmentos de la novela y se deben identificar los que a juicio de los estudiantes sean relevantes en cuanto a su contenido religioso.

Se leerá en voz alta y cada estudiante señala la fuente, página correspondiente.

ACTIVIDAD DE CIERRE: Elabore un aviso parroquial invitando a misa en Yolombó en la época de la Colonia.

En los siguientes links encontrarás mayor información sobre la religión en la "La Marquesa de Yolombó", formas, ritos e influencia.

http://www.ub.edu/geocrit/b3w-758.htm

http://www.scielo.br/pdf/bgoeldi/v8n2/14.pdf poder vivir a sus anchas. Cristo no iba a tratarlos mal, a ellos que habían traído y propagado su religión por estas Indias Occidentales. Pocos males podía hacerles el diablo: cruces y crucifijos no faltaban en las casas y todos los cargaban en sus rosarios" (Pág. 82)

\section{CONCLUSIÓN DE TEMA}

En cuanto al clero de aquella época, y muy especialmente del de Yolombó, habrá bien poco que encomiar, si no mientan la historia y la conseja. Los sacerdotes apostólicos y heroicos de que se ocupan los historiadores son contados; a la mayoría nos los pintan harto preocupados de sus intereses propios y temporales, y harto desentendidos de los de Cristo. La cura de almas no se cifraba tanto en el precepto y en el ejemplo cuanto en obligar a indios, mediante cárcel y azotes, a cumplir con los preceptos de la misa dominical, la comunión por Pascua y el pago de diezmos y primicias.

Tomado de A guisa de prólogo (Pág. 15) Tomás Carrasquilla. La Marquesa de Yolombó.

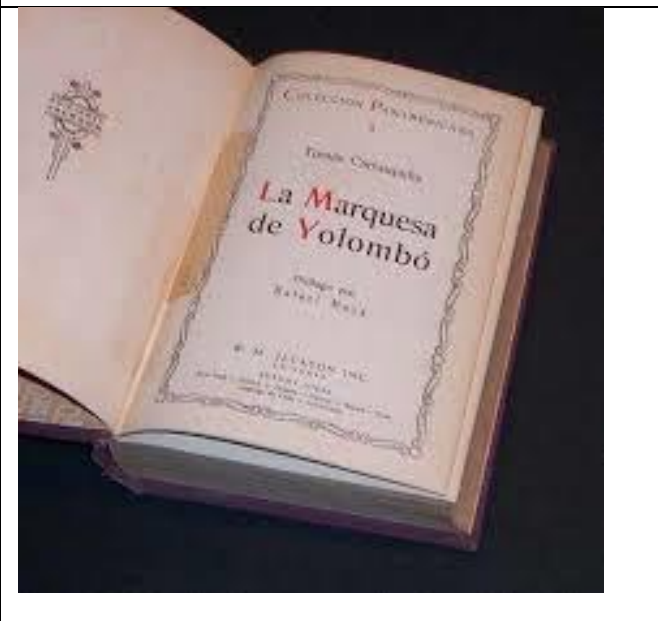


Tabla 3: Tema base: La minería

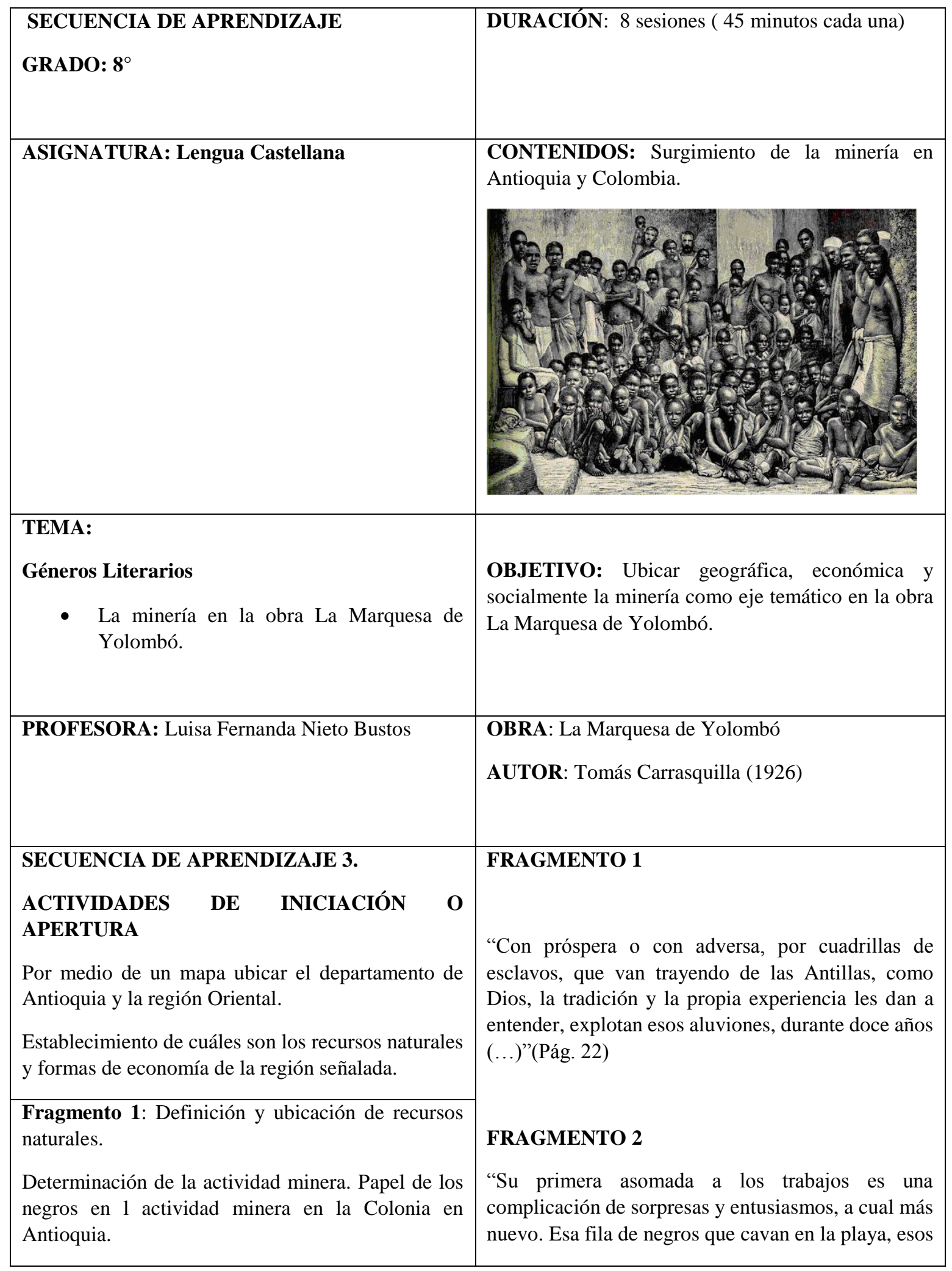




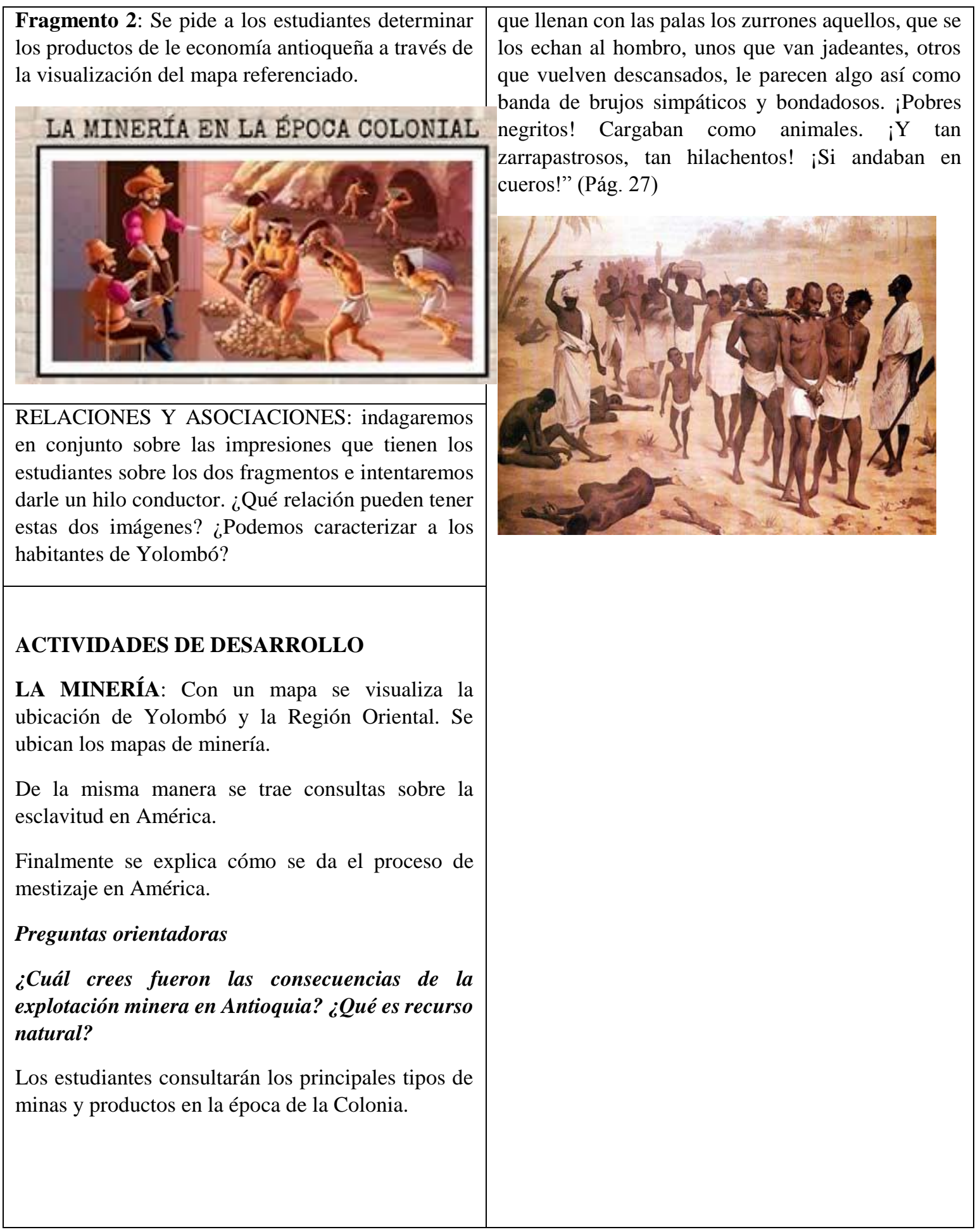




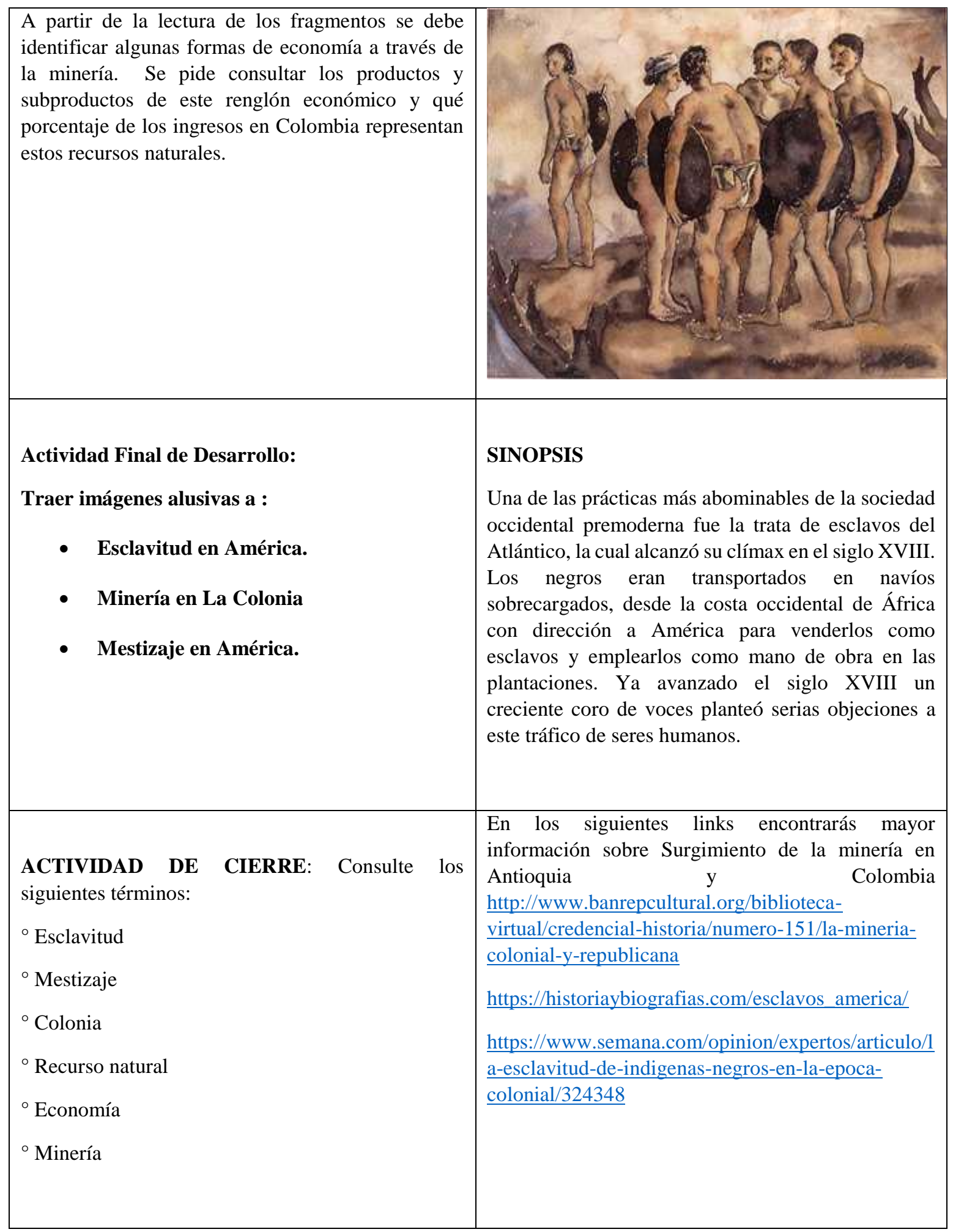


Tabla 4. Tema base: La Colonia

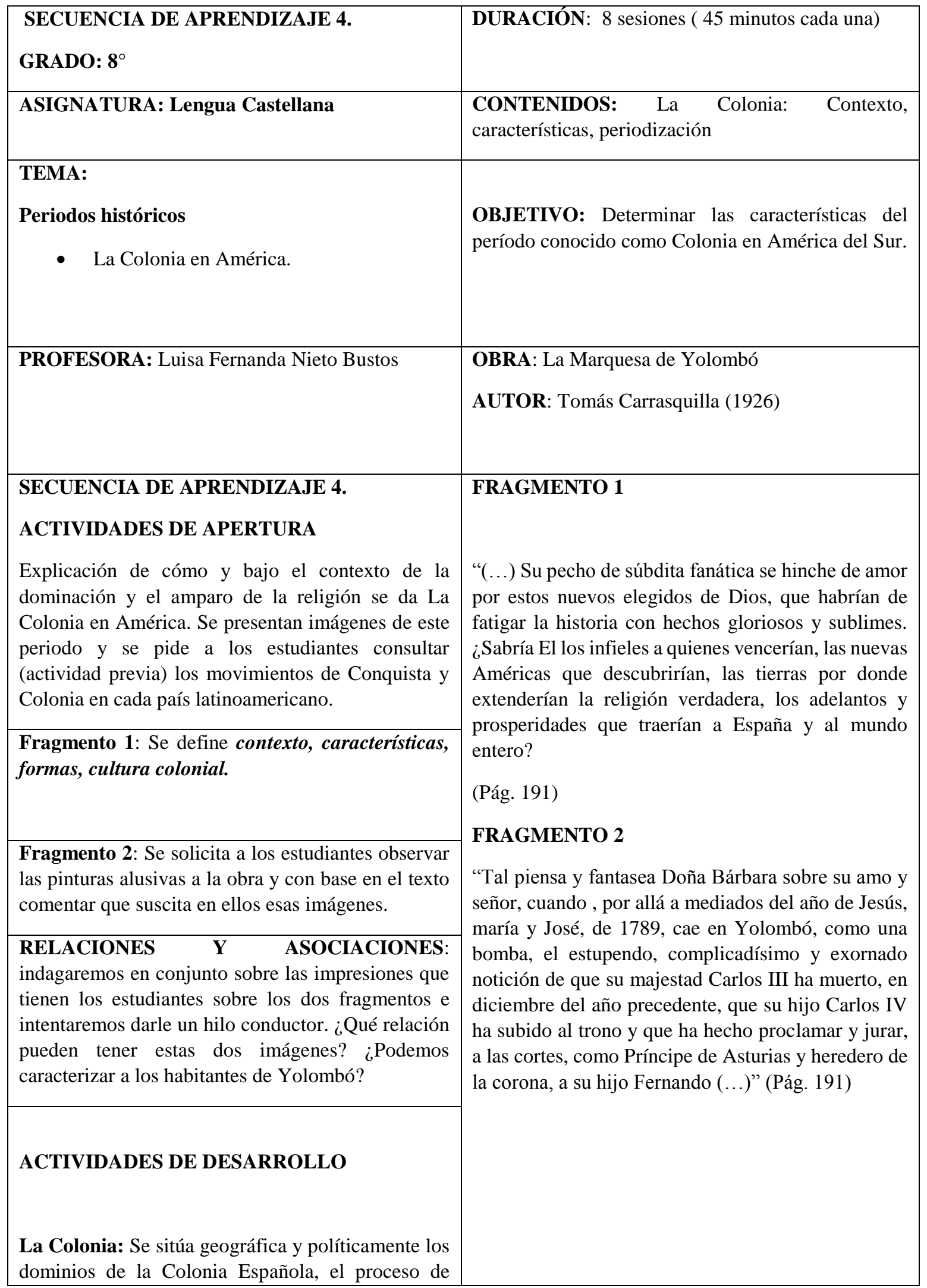




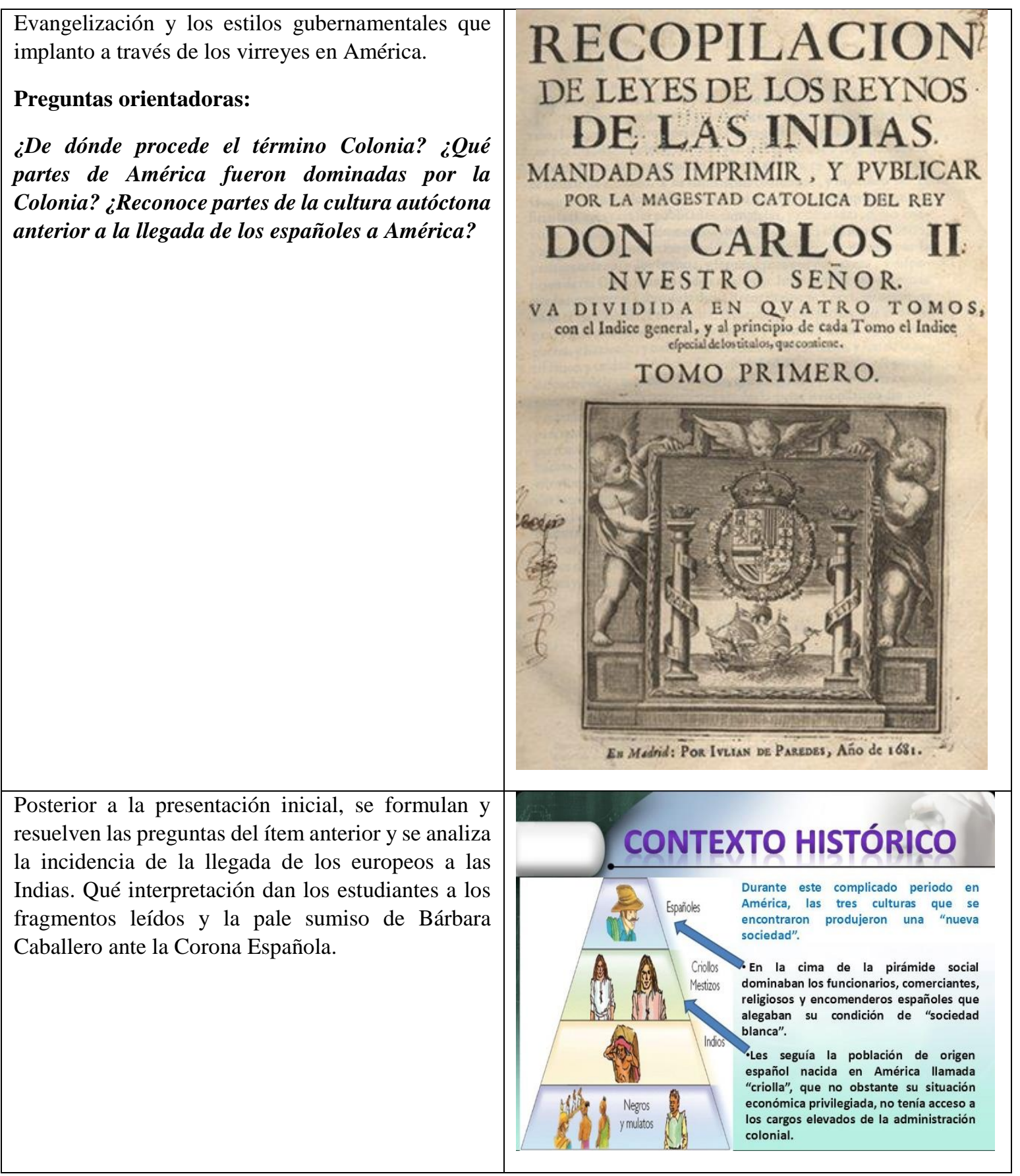




\begin{tabular}{|c|c|}
\hline & SINODSIS \\
\hline $\begin{array}{l}\text { Actividad 2: Se procede a la lectura del Capítulo X } \\
\text { para contrastar el trato que da La Marquesa a los } \\
\text { negros y la forma cómo se ha contado es le dado por } \\
\text { los españoles en las colonias. }\end{array}$ & $\begin{array}{l}\text { La época de la colonia comprende un largo periodo, } \\
\text { desde } 1550 \text { hasta } 1810 \text {. Durante estos años los } \\
\text { españoles se establecieron definitivamente en nuestro } \\
\text { territorio. La corona española organizo una } \\
\text { administración centralizada, con gran número de } \\
\text { funcionarios que debían garantizar el traspaso de las } \\
\text { riquezas americanas a la península ibérica. } \\
\text { La economía de la época giraba en torno a la minería, } \\
\text { la agricultura y el comercio, actividades } \\
\text { monopolizadas por el gobierno español. El trabajo } \\
\text { era realizado por los indígenas en la encomienda y la } \\
\text { mita y por los negros esclavos y jornaleros mestizos. } \\
\text { La sociedad se encontraba dividida en varios grupos } \\
\text { según el color de la piel y las riquezas, destacándose } \\
\text { los peninsulares y criollos que predominaban sobre } \\
\text { una gran masa de mestizos, indígenas y negros. } \\
\text { La cultura fue estimulada especialmente por los } \\
\text { sacerdotes, quienes evangelizaron a los indios, } \\
\text { fundaron colegios y universidades }\end{array}$ \\
\hline $\begin{array}{l}\text { ACTIVIDAD DE CIERRE: Consulte en un Atlas } \\
\text { los cambios geográficos y políticos que se } \\
\text { sucedieron en los periodos precedentes a la } \\
\text { Independencia y contrastarlos con la Colonia. }\end{array}$ & $\begin{array}{l}\text { En los siguientes links encontrarás mayor } \\
\text { información sobre La Colonia en América. } \\
\text { http://www.banrepcultural.org/biblioteca- } \\
\text { virtual/credencial-historia/numero-151/la-mineria- } \\
\underline{\text { colonial-y- }} \\
\text { republicanahttp://lacoloniaeci2006.blogspot.com/ } \\
\text { https://historiadecolombiaut2010.wordpress.com/art } \\
\text { es-y-cultura/conquista-y-colonia/ }\end{array}$ \\
\hline
\end{tabular}


Tabla 5: Tema base: La cultura y el folklor

\begin{tabular}{|c|c|}
\hline $\begin{array}{l}\text { SECUENCIA DE APRENDIZAJE } \\
\text { GRADO: } 8^{\circ}\end{array}$ & $\begin{array}{l}\text { DURACIÓN: } 8 \text { sesiones ( } 45 \text { minutos cada } \\
\text { una) }\end{array}$ \\
\hline ASIGNATURA: Lengua Castellana & $\begin{array}{l}\text { CONTENIDOS: Aspectos cultuales en La } \\
\text { marquesa de Yolombó. }\end{array}$ \\
\hline $\begin{array}{l}\text { TEMA: } \\
\text { La cultura } \\
\begin{array}{l}\text { - } \\
\text { - } \\
\text { - El folkgos }\end{array}\end{array}$ & $\begin{array}{l}\text { OBJETIVO: Ilustrar a través del texto } \\
\text { algunos elementos culturales referidos en La } \\
\text { Marquesa de Yolombó. }\end{array}$ \\
\hline PROFESORA: Luisa Fernanda Nieto Bustos & $\begin{array}{l}\text { OBRA: La Marquesa de Yolombó } \\
\text { AUTOR: Tomás Carrasquilla (1926) }\end{array}$ \\
\hline $\begin{array}{l}\text { SECUENCIA DE APRENDIZAJE } 5 . \\
\text { ACTIVIDADES DE INICIACIÓN O APERTURA } \\
\text { Preámbulo: Traer ilustraciones sobre pinturas, bailes, } \\
\text { reuniones, lugares públicos, construcciones, etc., en donde } \\
\text { se vislumbre elementos propios de la cultura. }\end{array}$ & $\begin{array}{l}\text { FRAGMENTO } 1 \\
\text { "De ahí en adelante seguía el visiteo de } \\
\text { felicitaciones, que tenía también su fórmula, } \\
\text { pero en estilo chancero. El visitante recitaba: } \\
\text { Beso } \\
\text { Y rebeso }\end{array}$ \\
\hline $\begin{array}{l}\text { Fragmento 1: Lectura de los versos que allí se declaman y } \\
\text { determinar elementos de uso común en la obra narrativa. } \\
\text { Se pide a los estudiantes reescribir el fragmento en términos } \\
\text { de hoy: establecer qué se pretendía significar con este tipo } \\
\text { de saludos. }\end{array}$ & $\begin{array}{l}\text { Planta, carcañal y hueso } \\
\text { Y vuelvo a besar } \\
\text { Planta, hueso y carcañal } \\
\text { El visitado respondía: }\end{array}$ \\
\hline $\begin{array}{l}\text { Fragmento 2: Se solicita a los estudiantes consultar los } \\
\text { elementos índice que refiere este segmento: Contradanza, } \\
\text { tonadillas, y bundes; asimismo indagar sobre su origen y } \\
\text { uso en la cultura colombina y antioqueña. }\end{array}$ & $\begin{array}{l}\text { Pago } \\
\text { Y repago }\end{array}$ \\
\hline $\begin{array}{l}\text { RELACIONES Y ASOCIACIONES: Revisar audios de los } \\
\text { géneros musicales que se nombran en el fragmento } 2 \text {. }\end{array}$ & Y vuelvo a pagar \\
\hline
\end{tabular}




\begin{tabular}{|c|c|}
\hline 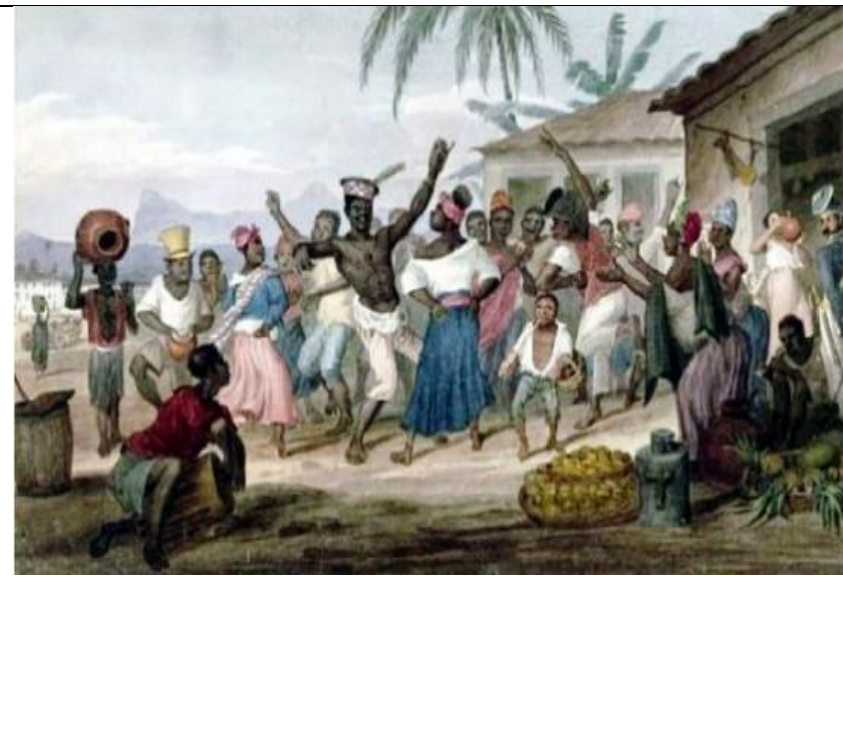 & $\begin{array}{l}\text { Favor, halago y besar. } \\
\text { (Pág. 85) } \\
\text { FRAGMENTO } 2 \\
\text { "Por la noche hay licor libre, de seis a siete. } \\
\text { A los que no van a l estanco se lo llevan a } \\
\text { donde estén; hay refresco bailable en casa de } \\
\text { la anfitriona. Pone la contradanza, aprendida } \\
\text { en Antioquia; luego, acompañada de Narcisa, } \\
\text { saca las tonadillas y los bundes, los arpegios y } \\
\text { panderetos, que se tenían atan guardados. La } \\
\text { beldad africana, habituada a estas } \\
\text { exhibiciones artísticas, se muestra, si muy en } \\
\text { ello, muy en su puesto de negra y de esclava } \\
\text { voluntaria. No sabe la hermosa todos los } \\
\text { corazones que quiebra" (Pág. 197) }\end{array}$ \\
\hline $\begin{array}{l}\text { Con base en la lectura, audios y explicación de los } \\
\text { fragmentos } 1 \text { y } 2 \text { se señalan los aspectos inherentes al } \\
\text { desarrollo e influencia del folclor como manifestación } \\
\text { cultural de la época. }\end{array}$ & \\
\hline $\begin{array}{l}\text { Actividad alternativa: Presentar carteleras alusivas a las } \\
\text { tradiciones y formas folclóricas de la región antioqueña en } \\
\text { la época de la Colonia. }\end{array}$ & \\
\hline $\begin{array}{l}\text { Desarrollo temático: Lectura del artículo referenciado en } \\
\text { la sinopsis y se realizan preguntas de comprensión del texto. } \\
\text { Se indaga el tema, postura del autor y la fidelidad con } \\
\text { hechos históricos consultados previamente. } \\
\text { Nota: Se realiza lectura mental. Se reparten las fotocopias } \\
\text { con el texto asignado. }\end{array}$ & $\begin{array}{l}\text { SINOPSIS } \\
\text { En el caso de la época de la Conquista y } \\
\text { comienzos de la Colonización, la Cultura } \\
\text { Folklórica va a estar representada en la de } \\
\text { aquellos indígenas que han sido reducidos a } \\
\text { villas y pueblos bajo la custodia de los } \\
\text { españoles. Estos grupos indígenas, sometidos } \\
\text { a un proceso de aculturación forzada, se verán } \\
\text { dificultados, si no impedidos del todo, de } \\
\text { realizar sus viejas tradiciones culturales } \\
\text { (especialmente las religiosas, debido al } \\
\text { carácter "salvacionista" de la empresa } \\
\text { conquistadora), obligados por consiguiente a }\end{array}$ \\
\hline
\end{tabular}




\begin{tabular}{|c|c|}
\hline & $\begin{array}{l}\text { aceptar fórmulas impuestas dirigidas a } \\
\text { destruir su cualidad étnica. } \\
\text { En relación a las manifestaciones llamadas } \\
\text { artísticas -según la tradición } \\
\text { occidental- veríamos que aquellas ligadas a } \\
\text { las festividades (música, danza, juegos, etc.,) } \\
\text { y al culto de divinidades (ritos, sacrificios, } \\
\text { etc.), deben haber sido las más reprimidas, } \\
\text { mientras que aquellas ligadas a actividades } \\
\text { susceptibles de ser incorporadas al incipiente } \\
\text { mercado de consumo colonial (tales como la } \\
\text { artesanía del barro: ollas, budares, ánforas; de } \\
\text { tejido vegetal: cestas, chinchorros, etc), deben } \\
\text { haber tenido cierta permisibilidad (incluso } \\
\text { esta presunción tiene vínculos con la realidad } \\
\text { actual, cuando encontramos una gran } \\
\text { presencia indígena en las artesanías y no en } \\
\text { los rituales, dentro de la Cultura Folklórica). }\end{array}$ \\
\hline $\begin{array}{l}\text { ACTIVIDAD DE CIERRE: Comparar las tres } \\
\text { ilustraciones de la secuencia } 5 \text { y realice un escrito de una o } \\
\text { dos páginas con respecto a las tradiciones culturales de la } \\
\text { Colonia en América. } \\
\text { En los siguientes links encontrarás mayor información } \\
\text { sobre aspectos cultuales en La marquesa de Yolombó. } \\
\text { https://ciscuve.org/2012/02/el-sujeto-social-creador-de- } \\
\text { folklore-desde-la-colonia-hasta-nuestros-dias-breve- } \\
\underline{\text { revision-historica/ }} \\
\underline{\text { https://www.youtube.com/results?search query=la+contra }} \\
\underline{\text { danza }} \\
\underline{\text { https://www.youtube.com/watch?v=hcxS2Ruqgx4 }} \\
\underline{\text { http://www.scielo.org.co/pdf/esupb/v23n51/v23n51a07.pd }}\end{array}$ & \\
\hline
\end{tabular}

A partir de esta secuencia didáctica se pretende que los estudiantes puedan analizar, comprender e interpretar los hechos históricos de la novela histórica la Marquesa de Yolombó, y de cualquier otra obra histórica, teniendo como base el proceso metodológico de la secuencia didáctica. 
Por ejemplo, en la actividad de apertura se buscó que los estudiantes a partir de unos conocimiento previos logren tener un acercamiento a la obra histórica, para que luego ellos desarrollen una narrativa de las imágenes que se encuentran en algunos fragmentos de la novela; y posteriormente el docente desarrolla generar un pensamiento de enseñanza, desde la asociación de los fragmentos y de las imágenes para encontrar un hilo conductor al texto.

Luego, aparece la actividad de desarrollo; desde la cual los estudiantes recuerdan algunos aspectos centrales de la cultura africana, las danzas y otros rasgos culturales. De la misma forma ellos investigan qué es la novela histórica, la biografía de Tomás Carrasquilla y el origen de la minería en Colombia, para tener un acercamiento contextualizado de la novela; después se da paso a realizar algunas preguntas en relación a lo trabajado en la clase, y para resolver estas inquietudes el docente sugiere trabajar en grupos, en ese aspecto, se resalta la necesidad de incentivar dentro de los procesos de enseñanza de la novela histórica el trabajo cooperativo entre docente y estudiantes, ya que esto permite entablar el diálogo y por supuesto generar diversos puntos de vista sobre la comprensión de los fragmentos de la obra histórica.

Y, finalmente, se encuentra la actividad de cierre que tiene por finalidad, generar un producto narrativo de la obra histórica de manera lúdica, en este caso se recurre a la historieta que es una historia explicada mediante viñetas o recuadros que contienen ilustraciones y textos breves, con esta estrategia didáctica se busca que el estudiante recoja los elementos centrales de la obra histórica; y así configurar un meta relato que responde a lo que el estudiante comprende y analiza críticamente de la novela. 


\section{CONCLUSIONES}

De la presente investigación se concluyeron cuatros aspectos a saber; el primer aspecto, se relaciona con la manera cómo la obra del autor colombiano Tomás Carrasquilla La Marquesa de Yolombó ha sido estudiada en ámbitos históricos, didácticos y pedagógicos, de la siguiente manera: En el primer tipo de estudios, la Marquesa de Yolombó en el ámbito histórico; se resaltó la función histórica de la Novela de Tomás Carrasquilla, de acuerdo a lo expresado por los investigadores, quienes resaltaron la importancia del lenguaje en la narrativa de la novela, dado que éste recrea y construye la vida de un pueblo colombiano en un determinado contexto histórico. A su vez, la novela reconstruye el devenir de los hombres por medio de parajes cargados de costumbres, descripciones y voces de los personajes que metafóricamente encarnan un sentimiento de libertad apaciguado por la Iglesia y el Estado, pero sin lugar a dudas describe magistralmente las nuevas representaciones culturales que surgieron de las relaciones de dominación, e interacción entre la cultura hispánica, negra e indígena.

Al mismo tiempo, Carrasquilla permite ubicar en la historia una paradoja que subyace a la dominación esclavista, los dominados no sólo se resistieron a los procesos de aculturación total, sino que se adaptaron a algunas formas socioculturales impuestas e hicieron importantes aportes a la sociedad dominante con la variedad y riqueza de sus conocimientos y sus artes. En el segundo tipo de estudios, la Marquesa de Yolombó desde su función estética y creadora; se constató en la obra, cómo desde la música, el verso y la danza, se convierten en elementos que vivifican la religiosidad y la mixtura cultural constitutiva de 
Yolombó; y, en el tercer tipo de estudios, la novela histórica en el campo de la pedagogía y la didáctica; se evidencia la importancia de fortalecer el aprendizaje de la historia con un elemento neutralizador - La novela-, la cual servirá como manifestación, ejemplificación, motivación y ubicación para el alumno ante los diferentes ambientes culturales de diferentes épocas históricas.

El segundo aspecto está relacionado a la comprensión del concepto de lectura literaria y la comprensión lectora, en los planes de lectura en las instituciones educativas. En el caso de la lectura literaria se argumentó la necesidad de desarrollar un aprendizaje adecuado en la enseñanza de la lectura literaria, desde una implicación personal del estudiante con la literatura, dado que esto favorece el desarrollo de habilidades de interpretación inferencial de las obras, o la diversificación de las formas de fruición propias del lector literario. Para este propósito, se recomienda utilizar textos de lectura literaria cuya textura formal o semántica facilite la comprensión de su significado pero a la vez inviten a la lectura en los estudiantes. Al mismo tiempo, se sugiere suscitar la implicación de los estudiantes en la lectura literaria en la medida que estos textos les traiga consigo algún tipo de placer estético y algún tipo de emoción que desarrolle en ellos la creatividad. Y, para lograr esto, es necesario implementar la didáctica de la enseñanza de la lectura literaria, que surge de la necesidad de generar estrategias de aprendizaje que contribuyan a la comprensión de los textos literarios.

En lo que respecta a la comprensión lectora se encontró que ésta busca que el estudiante comprenda lo que dice el texto a partir de su contexto, y luego su respectiva interpretación que conlleva a que se dé una interacción entre el lector y el autor de ese texto. Para tal efecto, existen dos requisitos básicos para el desarrollo de la comprensión lectora: primero, adquirir y dominar las habilidades de reconocimiento y decodificación de las 
palabras, y, segundo, adquirir habilidades de búsqueda y construcción de significados, los cuales permiten una mejor comprensión del sentido del texto. A su vez, se hizo énfasis en la necesidad de que cada estudiante en su proceso de comprensión lectora tenga la capacidad de interpretar los símbolos de cada lengua, para este propósito se requiere releer el texto para comprender su significado; y además a esto, comprender un texto presupone realizar un ejercicio comprensivo de los conocimientos previos sobre lo que se lee, ya que esto favorece la profundización del texto y así el lector tiene la capacidad de codificación la información leída en el texto; finalmente, la comprensión lectora contribuye a enseñar los procedimientos estratégicos que pueden capacitar a los alumnos para leer de forma autónoma y productiva, es decir, utilizando la lectura para aprender.

El tercer aspecto conclusivo tiene que ver con el análisis de los lineamientos curriculares, a partir de la vinculación de la lectura literaria de la novela histórica en los planes lectores, mallas curriculares y Derechos Básicos de Aprendizaje DBA, en las instituciones educativas, Tabora I.E.D ubicado en la Localidad $10^{\circ}$ Engativá y Fabio Lozano Simonelli de la Localidad $5^{\circ}$ Usme. A este respecto, se encontró dentro de la lectura literaria de la novela histórica en el caso de los lineamientos curriculares del MEN (2013), la importancia de promover la lectura literaria a partir de estudios comparados, desde dos obras históricas ( Pedro Páramo y la Odisea), para resignificar que estas novelas históricas contienen elementos textuales e interpretativos similares que contribuyen a comprender la importancia de la lectura literaria en estas obras, y así el estudiante desarrolle un sentido crítico y argumentativo en su proceso de enseñanza y aprendizaje de la lectura literaria.

En relación a los Estándares Básicos de Competencias de Lenguaje, de los grados 8 y 9, se encontró: primero, se rescató en el proceso de enseñanza que los estudiantes conozcan 
las obras latinoamericanas, sus elementos textuales a partir de sus características históricas y estéticas; y, segundo, la necesidad de incentivar en la comunidad estudiantil a leer con sentido crítico las obras literarias de autores latinoamericanos.

Por su parte, sobre los Derechos Básicos de Aprendizaje en los grados 8 y 9, específicamente de la lectura literaria de novelas históricas se evidenció en el proceso de aprendizaje con los estudiantes que ellos reconozca las producciones literarias como cuentos, novelas, fábulas, aspectos referidos a su estructura formal y la identidad cultural, y también la capacidad del estudiante de reconocer los diferentes narradores que nutren la historia en las novelas.

Para finalizar, aparece el plan de estudios del Colegio Tabora, el cual propone que los estudiantes de octavo y noveno grado conozcan la literatura del descubrimiento y la conquista (colonia- e independencia), de manera que el estudiante se apropie de estos textos históricos de literatura, y genere con esto un sentido crítico en la apropiación de estas obras literarias. Y, en el plan de estudios del Colegio Fabio Lozano Simonelli, se pudo entrever que la lectura literaria sobre la novela histórica se encuentra enmarcada dentro de la literatura de la época del neoclasicismo, el romanticismo, y obras literarias del legado colombiano; esto conlleva a que el estudiante desarrolle la comprensión e interpretación de obras literarias, para consolidar un pensamiento argumentativo y crítico con base en la lectura de estas novelas que se desarrollan en estas épocas de la historia.

Y, finalmente, aparecen algunos aspectos que se encontraron en la investigación sobre la propuesta didáctica de la siguiente manera: en un primer momento, se rescataron como categorías de la Marquesa de Yolombó: primero, la reivindicación de lo femenino; ya que esta obra representa la reivindicación de la lucha por los derechos de la mujer en esa época, y a partir de su visión emprendedora logra visibilizar en ese contexto social la importancia 
de reconocer y la valor la dignidad de la mujer en la sociedad, se trata de una afirmación personal de la Marquesa por los valores de las mujeres, en contra del poder hegemónico de la época, en el cual la dominación patriarcal ejercía control sobre la sociedad. Segundo, el costumbrismo; puesto que La Marquesa de Yolombó es una novela histórica que reconstruye el pasado de una población antioqueña en el siglo XVIII, a fines de la Colonia y principios de la Independencia. Tercero, el lenguaje; en la medida que Carrasquilla en su única novela histórica, ilumina el proceso de construcción de una lengua nacional, con base en elementos culturales, lingüísticos propios del territorio Antioqueño; y, cuarto, el sincretismo étnico cultural; el cual a través de la música por medio de pasajes donde las fiestas, celebraciones públicas y religiosas dejen escuchar las armonías de contradanzas, bundes, torbellinos; que son expresiones artísticas que componen la gama cultural que se hallaba desde la conquista en tierras americanas y que comienzan a transformarse como resultado del contacto intercultural desde la época colonial en Yolombó.

Luego, se abordó la importancia de la didáctica en el proceso de enseñanza y aprendizaje, por lo cual su implementación es un factor determinante al momento de generarse el acto de enseñar y aprender dentro y fuera del aula o en diferentes escenarios educativos; luego, aparece la didáctica de la literatura, cuya finalidad, es que el estudiante desarrolle competencias comunicativas, a su vez que éste tenga la capacidad de generar una lectura crítica de las obras literarias, de manera que el estudiante pueda generar procesos de enseñanza y aprendizaje de la lectura literaria de las novelas históricas, desde una postura crítica contextualizada de lo que propone el autor en la obra; en esa dinámica, se encontraron valiosos aportes de la didáctica de la lectura literaria de obras históricas, las cuales favorecen la asimilación de los aprendizajes, ya que los estudiantes recuerdan mejor la lectura de 
determinados textos si se halla incluida en el recuerdo global de un tipo de actividad extensa y con sentido propio; y, finalmente, la didáctica crítica de la lectura literaria de las obras históricas, las cuales debe promover en la adecuada revisión de los personajes, los temas de la obra de manera reflexiva, los capítulos específicos con las respectivas inferencias de lo leído, en cuanto esto contribuye a que el estudiante desarrolle un proceso de aprendizaje consciente, interpretativo y crítico de las obras históricas.

Posteriormente, se desarrollaron algunas estrategias de la lectura literaria de la novela histórica, de lo cual se pretende que el docente recurra a estrategias de las TIC para incorporarlas en los procesos de enseñanza de la lectura literaria de la novela histórica, desde esta perspectiva, se busca a través de los medios digitales y audiovisuales promover un aprendizaje de la lectura y la escritura dinámicos. Y, para finalizar se establecieron algunos aspectos vitales de la secuencia didáctica para los procesos formativos de los docentes, para ello, se recomienda que el docente identifique qué aspectos de su práctica pedagógica deben alterarse y cómo; luego, en qué dimensiones hay que trabajar a nivel de centro o qué haya que reclamar de la política educativa; para este propósito, se requiere de la innovación en la didáctica de la lectura literaria de la novela histórica en los centros educativos, con base en el modelo de la secuencia didáctica: actividades de apertura, desarrollo y cierre.

Al final de esta investigación se llevó a cabo el diseño de una propuesta didáctica que facilite a docentes y estudiantes una lectura literaria de la obra la Marquesa de Yolombó, y que por tanto, se integre al plan lector del curso de octavo grado. La estrategia por utilizar se basa en un modelo de análisis que integre la visión del texto narrativo desde los ámbitos de lo histórico, lo literario y lo pedagógico dado las temáticas que se entrecruzan en el texto de Carrasquilla. Esto supone, que al finalizar la lectura de esta novela, el estudiante pueda 
comprender, la dimensión de los hechos históricos que allí se mencionan en la obra; la forma en que el autor los aborda, el hecho educativo que hay inmerso en el relato y el valor desde lo estético de la misma obra, con base en los temas: reivindicación de lo femenino, costumbrismo, lenguaje y sincretismo cultural, los cuales son fundamentales para la creación narrativa de la lectura literaria de esta obra histórica. 


\section{REFERENCIAS}

Alcaldía Mayor de Bogotá (2015). Plan Distrital de y Escritura “Leer es Volar”. Recuperado de http://www.culturarecreacionydeporte.gov.co/biblioteca/descargables/Plan\%20de\%2 0lectura_100217.pdf

Arango, M., (2014). La Marquesa de Yolombó: una mirada a las mujeres coloniales antioqueñas. Revista Iberoamericana (23): 2- 29.

Arturo, G. C. (2012). El mundo de la Vida. Bogotá, Colombia: Apostol.

Barbero, J. M. (1992). Televisión y melodrama. Calí, Colombia : Tercer Mundo.

Barriga, A., (2013). Secuencias de aprendizaje. ¿Un problema del enfoque de competencias o un reencuentro con perspectivas didácticas? Revista Currìculum y formación del profesorado (3): 2-29.

Bofarull, Et al. (2001). Comprensión lectora. El uso de la lengua como procedimiento. Madrid, España: Grao

Bolívar, A., (2011). La didáctica en el núcleo del mejoramiento de los aprendizajes. Entre la agenda clásica y actual de la Didáctica. Revista Educacional, 50 (2): 2-30.

Buchelli, G., (2009). Transposición didáctica: bases para repensar la enseñanza de una disciplina científica. Revista académica e institucional de la UCPB, (3): pp. 10.- 40.

Calvo, V., y Tabernero, R., (2014). La lectura literaria y la escritura virtual en la educación inclusiva. Una investigación cualitativa con adolescentes inmigrantes, en el contexto 
educativo de España. Revista Latinoamericana de Educación Inclusiva, 23, (3): 110129.

Camps, A., (2013). Hacia un modelo de enseñanza de la composición escrita en la escuela. Recuperado de, file:///D:/Downloads/ANA\%20CAMPS.pdf

Cervantes, A. C. (2005). La Telenovela Colombiana: Un relato que reivindicó las identidades marginadas. Investigación y desarrollo vol. 13, $n^{\circ} 2$-, $32-61$.

Colomer, T., ( 1995). La adquisición de la competencia literaria. Revista textos ( 4): 3- 32.

Colomer, T., ( 1995). La didáctica en la literatura: temas y lineas de acción en la investigación. Recuperado de, file:///D:/Downloads/COLOMER\%202\%20(1).pdf

Copper, J., (1990) Cómo mejorar la comprensión lectora. Madrid, España: Visor Aprendizaje.

Cuesta, C., (2013). La enseñanza de la literatura y los órdenes de la vida: lectura, experiencia y subjetividad. Revista Universidad Nacional de Colombia 3, (23): 100- 134.

Forero, G. (2008). La Marquesa de Yolombo, entre novela etnográfica y novela histórica. Estudios de Literatura Colombiana, 110.

Franco, A. (2014). La Voz del Personaje femenino en la costrucción de una posición realista crítica desde la Marquesa de Yolombó de Tomás Carrasquilla. La palabra $N^{\circ} 24$.

Gispert, C. (2001). Lectura y memorización. Madrid, España: Editorial Océano

Gómez, M. (2010). Didáctica de la Filosofía. Bogotá, D.C., Colombia: Ediciones USTA

Gutiérrez, C., (2012). Estrategias de comprensión lectora: enseñanza y evaluación en educación primaria. Revista Currìculum y formación del profesorado, 12 (2): 2-29.

Hauy, H., (2014). Didáctica de la lectura literaria. Revista del Instituto de Estudios en Educación Universidad del Norte, 12 (3): 23-45.

Hernández, R. H. (2004). Didáctica de las Ciencias Sociales. Bogotá: Ediciones USTA. 
Hoyos, A., y Gallego, T., (2017). Desarrollo de habilidades de comprensión lectora en niños y niñas de la básica primaria. Revista virtual católica del Norte, 51, (3): 2-39.

Larrosa, J. (2007). La experiencia de la lectura: estudios sobre literatura y formación. México: Fondo de Cultura Económica

Lomas, C., (2014). La educación lingüística, entre el deseo y la realidad. Competencias comunicativas y enseñanza del lenguaje. Barcelona, Madrid: Octaedro. , __ (2006). Enseñar lenguaje para aprender a comunicarse. La educación lingüística y el aprendizaje de las competencias comunicativas. Bogotá, Colombia: Editorial Magisterio.

Mayoral J., (1987). Pragmática de la comunicación literaria. Madrid, España: Arco Libros. MEN (2003). Estándares básicos de competencia del lenguaje. Recuperado de, https://www.mineducacion.gov.co/1621/articles-116042_archivo_pdf1.pdf

, (2013). Serie lineamientos curriculares Lengua castellana. Recuperado de, https://www.mineducacion.gov.co/1621/articles-339975_recurso_6.pdf

_. (2015). Derechos básicos de Aprendizaje. Recuperado de, http://aprende.colombiaaprende.edu.co/sites/default/files/naspublic/DBA_Lenguaje. pdf

Merino, C., (2011). Lectura literaria en la escuela. Revista Horizontes educacionales, 16(1): 41-56.

Munita, C., (2017). La didáctica de la literatura: hacia la consolidación del campo. Revista Pesquisa, 23 (2): 370- 389.

Navas, E. M. (2014). La Novela Histórica como apoyo para la enseñanza de la historia en méxico. La Colmena, 57-67. 
Osorio, B. (2008). La Marquesa de Yolombó. La independencia vivida en el ámbito de la lengua. Estudios de Literatura Colombiana, 110.

Perez, L. A. (1982). La Marquesa de Yolombó y el mito en la literatura hispanoamericana. Hispania, 377-382.

Petit, M. (2001). Lecturas: del espacio íntimo al espacio público. México: FCE.

Restrepo, C. (2003). Cantos e interacción cultural en La Marquesa de Yolombó de Tomás Carrasquilla. Estudios de Literatura Colombiana, 25-40.

Restrepo, S. ( 2009). La estética de la fealdad en Tomás Carrasquilla. Estudios de Literatura Colombiana No. 24, 10.

Rodríguez, A., (2007). Lectura crítica y escritura significativa. Acercamiento didáctico desde la lingüística. Revista Universidad Pedagógica Experimental, (23): 240- 289.

Sánchez, M., (1995). Los textos expositivos. Estrategias para comprensión de la lectura. Madrid, España: Santillana

Sanz, A., (2003). Cómo diseñar actividades de comprensión lectora. Navarra, España: Grao Solé, I., (1998). Estrategias de lectura. Barcelona, España: Grao.

Solé, I. (1987). Las posibilidades de un modelo teórico para la enseñanza de la comprensión lectora, Revista Infancia y Aprendizaje 39, (9): 1-14.

Vallejo, R., (2015). Aproximación didáctica de la literatura en Colombia. Recuperado de, file:///D:/Downloads/VALLEJO.pdf

___ (2015). Retrospectiva de la didáctica. Recuperado de, file://D:/Downloads/vallejo\%202.pdf 
La Marquesa de Yolombó: Una propuesta didáctica de la Lectura Literaria. 118 